NMP-PLS-930182, Rev. 2

\title{
Technical Data Summary Supporting the Spent Nuclear Fuel Environmental Impact Statement, March 1994
}

by

R. L. Geddes

Westinghouse Savannah River Company Savannah River Site

Aiken, South Carolina 29808

R. E. Claxton

J. D. Lengel

J. D. Logue

R. S. Matthews

D. MoWhorter

This paper was prepared in connection with work done under the above contract number with the U.S.

Department of Energy. By acceptance of this paper, the publisher and/or recipient acknowledges the U.S. Government's right to retain a nonexclusive, royalty-free license in and to any copyright covering this paper, along with the right to reproduce and to authorize others to reproduce all or part of the copyrighted paper.

DISTRIBUTION OF THIS DOCUMENT IS UNLIMITED

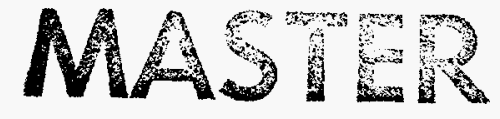




\section{DISCLAIMER}

This report was prepared as an account of work sponsored by an agency of the United States Government. Neither the United States Government nor any agency thereof, nor any of their employees, makes any warranty, express or implied, or assumes any legal liability or responsibility for the accuracy, completeness, or usefulness of any information, apparatus, product, or process disclosed, or represents that its use would not infringe privately owned rights. Reference herein to any specific commercial product, process, or service by trade name, trademark, manufacturer, or otherwise does not necessarily constitute or imply its endorsemeat, recommendation, or favoring by the United States Goverament or any agency thereof. The views and opinions of authors expressed herein do nor necessarily state or reflect those of the United States Government or any agency thereof.

This report has been reproduced directly from the best available copy.

Available to DOE and DOE contractors from the Office of Scientific and Technical Information, P. O. Box 62, Oak Ridge. TN 37831; prices available from (615) $576-8401$.

Available to the public from the National Technical Information Service, U. S. Deparment of Commeree, 5285 Port Royal Rd., Springfield. VA 22161 
SAVANNAB RIVER SITE

Westinghouse sayannah River Company

\section{TECHNICAL DATA SUMMARY SUPPORTING THE} SPENT NUCLEAR FUEL ENVIRONMENTAL IMPACT STATEMENT (U)

Revision 2

MARCH， 1994

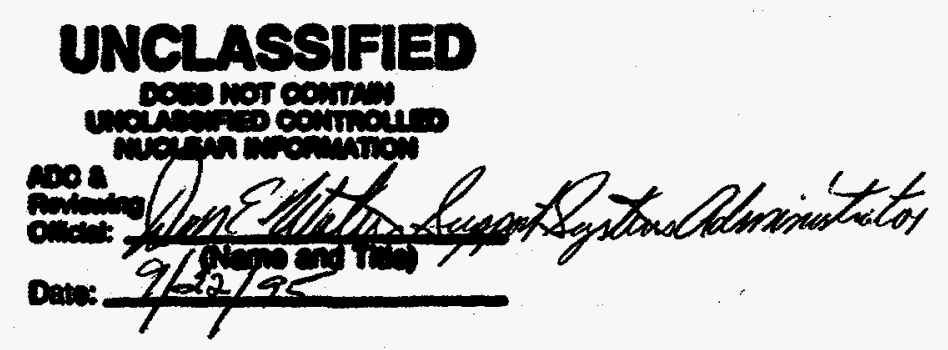

INFORMATION ONLY 
Technlcal Data Summary Supporting the

Document No. MMP-PLS-930182, Ravision 2

Karch 23, 1294

Document No.: NMP-PLS-930182

Revision 2

Retention: Iifetime

\section{TECHNICAI DATA SUMMARY SUPPORTING THE SPENT NUCIEAR FUEL ENVIRONMENTAI IMPACT STATEMENT \\ (U) \\ Revision 2}

Approved By:
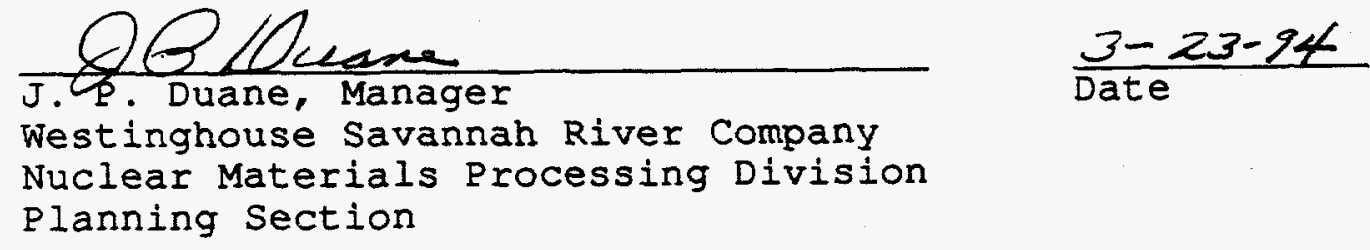

Contributors:

R. E. Claxton

R. L. Geddes

J. D. Lenge 1

J. D. Logue

Dr. D. C. Losey

R. S. Matthews

D. L. McWhorter

A. P. Poon

W. G. Smith

Dr. K. M. Vashi

D. W. Nelson

J. M. Owen

C. G. Phillips 
Technlaal Data Sumary Supporting the INEL Spent Fuel EIS

\section{Summary of Revisions}

Revision 1:

- In each of the options in Revision 0, there was a processing alternative that dissolved the spent fuels, then encapsulated the radioactive materials in borosilicate glass. This processing alternative case was deleted for all options.

- Added a case to the Centralization option which would transfer the SRS spent fuels to a central site other than SRS.

- In the two storage cases proposed for each option, the summary specifically designated the $K$ Reactor Basin as the interim storage basin. In this revision, no specific basin is recommended as the interim storage basin.

- Added Section 7 which evaluates the impact that the disposition alternatives may have on the air and water emissions for $E$ and $H$ Areas.

Revision 2:

- The reprocessing of the spent fuels was restricted to only the current inventory of SRS aluminum clad spent fuels. This has added the requirement for additional storage capacity in all the cases, especially the Centralization case. This has also eliminated the need for the modules associated with reprocessing the non-aluminum clad spent fuels.

- All reprocessing of spent fuels will be restricted to H-Area facilities. Only the Pu targets will be processed in F-Area.

- The costs of a future treatment facility have been significantly revised to more accurately reflect the total costs to develop, construct and operate this facility.

- The planning period was reduced from fifty (FY-44) to forty $(E Y-35)$ years.

- Added a Table of Contents, List of References, List of Figures, List of Tables, and List of Acronyms.

- This revision is a major alteration; therefore changes in the text are not denoted. 
Technical Data Summary Supporting the INEL Spent Fuel EIS

IV. TABLE OE CONTENTS

I. TITLE. PAGE

Rage

II. APPROVAL PAGE

III. SUMMARY OF REVISIONS

i i

IV. TABLE Of CONTENTS

V. SECTION 1 - INTRODUCTION

VI. SECTION 2 - OVERVIEW OF OPTIONS AND CASES

iii

iv

VII. SECTION 3 - METHODOLOGY OF ANALYSIS AND COSTING BASIS

- 7

VIII. SECTION 4 - CASE SUMMARIES 10

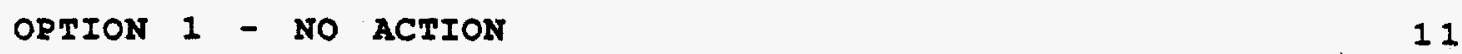

Module D - Spent Fuel Repackaging Facility

Canister loading Facility

Module $F$ - Interim. Dry Storage Facility 127

$\begin{array}{lll}\text { Module G - Interim Storage Spent Fuel Storage } & \\ \text { Pool } & & 129\end{array}$ 
Technical Data summary supporting the INEL spent Fuel EIS

Document No. NMP-PLS-930182, Revision 2

March 22. 1294

IV. TABLE OF CONTENTS (Continued)

pare

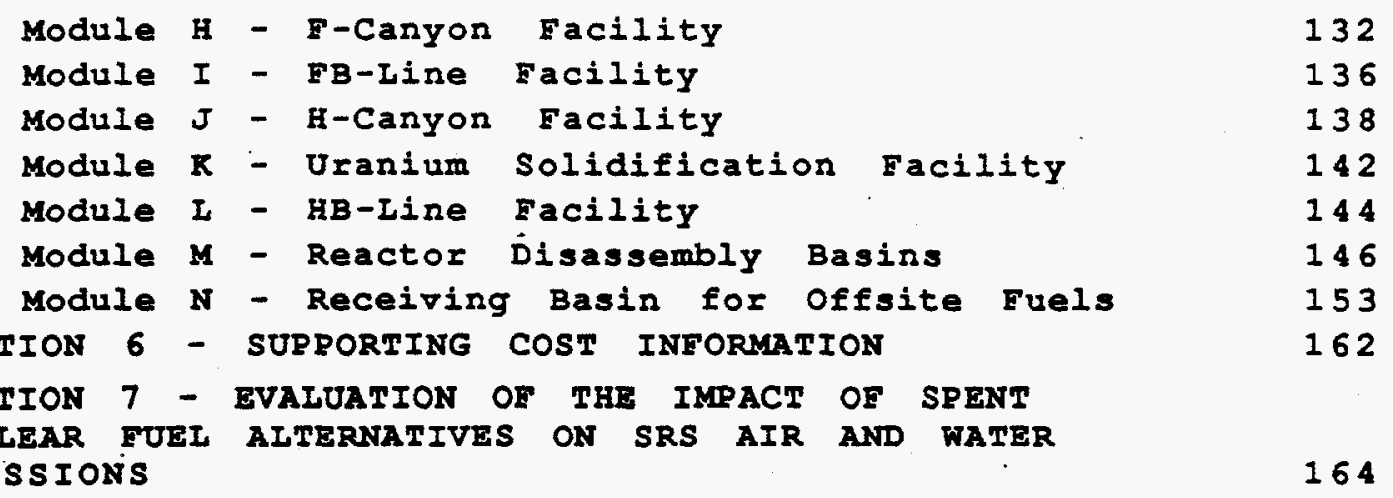

XII. ATTACHMENTS

Attachment 1 - Air Emissions Data

Attachment 2 - Water Emissions Data (Retain from Revision 1) 
Technical Data summary supporting the INEL spent Fuel EIS

\section{IIST OF FIGURES}

Number

Desariotion

Rage

Figure 1 Overall Flow Chart

Figure 2 Flow Chart for Case $1 \quad 15$

Figure 3 Flow Chart for Case 2a 23

Figure 4 Flow Chart for Case 2b 30

Figure 5 Flow Chart for Case 2c 37

Figure 6 Flow Chart for Case 3a 45

Figure 7 Flow Chart for Case 3b 51

Figure $8 \quad$ Flow Chart for Case $3 c \quad 58$

$\begin{array}{lll}\text { Figure 9 Flow Chart for Case } 4 \text { a } & 67\end{array}$

Figure 10 Flow Chart for Case 4b

$\begin{array}{lll}\text { Figure } 11 & \text { Flow Chart for Case 4c } & 81\end{array}$

$\begin{array}{lllrl}\text { Figure } 12 & \text { Flow Chart for Case 5a } & 89\end{array}$

Figure 13 Flow Chart for Case 5b

Figure 14 Flow Chart for Case 5c 103

Figure 15 Flow Chart for Case 5d 109 


\section{IIST OF TABIES}

Number

Table 1

Table 2

Table 3

Table 4

Table 5

Table 6

Table 7

Table 8

Table 9

Table 10

Table 11

Table 12

Table 13

Table 14

Table 15

Table 16

Table 17

Table 18

Table 19

Table 20

Table 21

Table 22

Table 23

Table 24

Table 25

Table 26

Table 27

Table 28

Table 29

Table 30

Table 31

Table 32

Table 33
Descriptien

Personnel and Cost Data for Case 1

waste and Emissions Data for Case 1

Fersonnel and Cost Data for Case 2 a

17

24

waste and Emissions Data for Case 2a

Personnel and Cost Data for Case $2 b$

31

Waste and Emissions Data for Case $2 \mathrm{~b}$

32

Personnel and Cost Data for Case $2 \mathrm{c}$

38

Waste and Emissions Data for Case 2c

39

Personnel and Cost Data for Case $3 a$

46

Waste and Emissions Data for Case $3 a$

47

Personnel and Cost Data for Case $3 b$

52

Waste and Emissions Data for Case $3 b$

53

Personnel and Cost Data for Case $3 \mathrm{C}$

59

60

waste and Emissions Data for Case $3 \mathrm{C}$

68

Personnel and Cost Data for Case $4 \mathrm{a}$

69

75

Personnel and Cost Data for Case 4b

76

waste and Emissions Data for Case $4 b$

82

Personnel and Cost Data for Case $4 \mathrm{C}$

83

Waste and Emissions Data for Case $4 \mathrm{C}$

90

Personnel and Cost Data for Case 5 a

91

Waste and Emissions Data for Case 5 a

97

Personnel and Cost Data for Case 5b

98

Waste and Imissions Data for Case 5b

104

Personnel and Cost Data for Case 5c

105

waste and Emissions Data for Case 5c

110

Personnel and Cost Data for Case $5 d$

111

157

160

161

161

163 


\section{Iist of References}

1. DOE Memorandum, R. S. Rothman from John J. Jicha, titled "Spent Nuclear Fuel Input for the INEI Complex wide EIS," dated September 10, 1993

2. DOE Report, titled "Spent Nuclear Fuel Policy," issued by John J. Jicha, dated June 28, 1993

3. DOE Report, titled "National Spent Fuel Management Plan," issued by Arvid Jensen, dated November 15, 1993

4. WSRC Document No. 920028 , titled "F-Canyon AND Associated racilities Deinventory Plan," Revision 0, dated September 30. 1992, issued by the MMPD Planning Group

5. FSRC Document No. NMP-PIS-920044, titled "H-Canyon and Associated racilities phaseout plan," Revision 0 , dated September 17, 1992, issued by the MMPD Planning Group

6. WSRC Document No. NMP-PLS-9300201, titled "F-Canyon and Associated Facilities Transition Plan," Revision 0, dated Norember 19, 1993, issued by the NMPD Planning Group

7. DOE Report, titled "Spent ruel Background Report," Predecisional Draft, dated June 25, 1993 issued by IT Corporation

8. Document No. wINCO-1119 UC-510, titled "Criticality safety Issues Associated with the Burial of Highly Enriched Nuclear Fuel in a Geologic Repository," issued by B. Palmer, NINCO

9. Document No. PNL-8072 UC-812, titled "Foreign Experience on Effects of Extended Dry storage on the Integrity of spent Nuclear Fuel," dated April, 1992, issued by $x$. J. Schneider and $S$. J. Mitchell of Pacific Northwest Laboratory

10. Document No. WSRC-RP-93-857, titled "DOE Spent Fuel storage Capability in RBOF," Draft, dated June, 1993, issued by $E$. N. Moore and others of the wSRC Planning support and Analysis Group 


\section{Iist of References \\ (Continued)}

11. WSRC Document No. SRT-SEP-930???, titled "Risk of spent FueI Process/Treatment/Storage Options, Draft, dated December, 1993, issued to $O$. M. Ebra-Iima from $J$. R. Schornhorst

12. FSRC Document No. MMP-PIS-930008, titled "Un-Irradiated Euel Disposition Alternatives," dated January 13, 1993, issued to J. P. Duane from H. G. Smith

13. HSRC Document No. SRT-MTS-930138, titled "status Report on Corrosion of Aluminum Alloys in SRs Reactor Disassembly Basin storage (U)," dated September 27, 1993 issued to S. D. Burke from J. P. Howell, SRTC 
Technical Data Summary Supporting the INEL spent Fuel EIS Document No. NMP-PLS-930182, Revision 2

March 22, 1994

\section{IIST OF ACRONYMS}

$\begin{array}{ll}\text { Al - } & \text { Aluminum } \\ \text { CDR - } & \text { Conceptual Design Report } \\ \text { D\&D - } & \text { Decommission and Dismantle } \\ \text { DBA - } & \text { Design Basis Accident } \\ \text { DBE - } & \text { Design Basis Earthquake } \\ \text { DBT - } & \text { Design Basis Tornado } \\ \text { DOE - } & \text { Department of Energy } \\ \text { EIS - } & \text { Environmental Impact Statement } \\ \text { FRR - } & \text { Foreign Research Reactor } \\ \text { HEU - } & \text { Highly Enriched Uranium } \\ \text { LEU - } & \text { Low Enriched Uranium } \\ \text { NMPD - } & \text { Nuclear Materials Processing Division } \\ \text { Pu - } & \text { Plutonium } \\ \text { R\&D - } & \text { Research and Development } \\ \text { RBOE - } & \text { Receiving Basin for offsite Fuels } \\ \text { ROD - } & \text { Record of Decision } \\ \text { RR - } & \text { Research Reactor } \\ \text { S\&M - } & \text { Surveillance and Maintenance } \\ \text { SRS - } & \text { Savannah River Site } \\ \text { SST - } & \text { Stainless Steel } \\ \text { WSRC - } & \text { Westinghouse Savannah River Company } \\ \text { Zr - } & \text { Zircaloy }\end{array}$


Technical Data Summary supporting the INIL spent Fuel IIS

Document No. NMP-PLS-930182, Revision 2

March 22, 2924

\section{SECTION 1}

\section{INTRODUCTION}


Section 1

Technical Data summary supporting the INEL spent Fuel EIS

Document No. NMP-RLS-930182, Revision 2

March 22, 2294

\section{Section 1 - Introduction}

This report has been compiled by the WSRC Nuclear Materials Processing Division's Planning Section at the request of the office of Spent Fuel Management and Special Projects (EM-37) to support issuance of the spent Nuclear Euel Environmental Impact Statement. Savannah River Site input data evaluates five programmatic options (including "No Action") ranging up to transfer of all DOE responsibility. spent fuel to the SRS. For each option, a range of management/disposition scenarios has been examined.

Each case summary provides information relative to the technical proposal, technical issues, environmental impacts, and projected costs for a forty year period (FY-35) when it is assumed that the material will be dispositioned from the SRS.

It must be recognized that the original issue of the report which was prepared under severe time constraints contained many simplifications and assumptions. Although the revisions have corrected some of the shortcomings of the original report, it is still highly recommended that significant additional study be performed before basing key decisions upon the data contained in this report. The data represents the best effort by a significant group of technical personnel familiar with nuclear materials processing, handling, and storage; but it is likely that careful scrutiny will reveal numerous discrepancies, inconsistencies and omissions. Nor does this report attempt to analyze every potential disposal pathway, but probably establishes the bounds for the most of the viable pathways.

The bulk of the effort went into defining the engineering approaches necessary to execute the various mission scenarios which were changed since the last revision. The decision to limit reprocessing to only SRS aluminum clad required a major alteration of the TDS. Collection and/or calculation of much of the various waste, emission, and utility consumption data, so important to an EIS, has been updated since the last revision, but not thoroughly completed. 
Technlcal Data summary supporting the INEL Spent Fuel EIS Document No. NMP-PLS-930182, Revision 2

March 22, 1924

\title{
SECTION 2
}

\author{
OVERVIEW OF
}

\section{OPTIONS AND CASES}


Section 2

Technical Data Summary Supporting the INEL spent Fuel EIS Document No. NMP-RLS-930182, Revision 2

March 22, 1294

\section{Section 2 - Overview of Options and Cases}

WSRC was presented with the guidance for the Technical Data Summary in Reference 1 with additional guidance coming from References 2 and 3 . In Reference 1, there is a matrix showing the options to be considered at each site plus data relative to the current and projected stock of DOE SNF, with the quantities to be considered at each site under each option. The guidance in Reference 1 has been amended as described in the summary of Revisions.

option 1 - No Action

In the existing facilities, the solution inventories and other materials as required for safety will be processed. No fuels will be shipped or received from SRS. The SRS spent fuel inventory may be relocated to optimize the use of existing facilities in the performance of a storage mission.

Although maintenance of existing facilities is permitted in this scenario, the limited life of aluminum clad fuels in existing wet storage pools limits this scenario to a time frame of about 15 years. By 2010, this is no longer a viable case.

Option 2 - Decentralization

As in the first option, the existing SRS spent fuel inventories are managed with no shipments or receipts. However, various alternatives are considered to provide SNF management through the end of the planning period. Three cases have been considered:

Case $2 a$ - Processing only the aluminum clad spent fuel and Pu target inventory to an SNM product form with interim storage in a vault. The special clad spent fuels will be placed into interim dry storage.

Case $2 b$ - Providing interim wet storage for the described spent fuel inventory by placement in new wet storage facilities. The aluminum clad spent fuels will be encapsulated in a stainless steel canister prior to placement in the new wet storage facility. Although it may be necessary based on the Hanford experience, SRS does not plan to repackage the special clad spent fuels prior to placement in the new wet storage facilities.

Case $2 c$ - After constructing the facilities necessary to repackage and store the existing SRS spent fuel inventory, it will be placed in new dry storage facilities similar to those found in commercial nuclear power plants. 


\section{Option 3 - Planning Basis}

With this option, SRS will manage planned the research reactor spent fuel inventory in addition to the SRS inventory. The guidance in Reference 1 was interpreted to mean that in addition to current inventories, all entire aluminum clad research reactor spent fuel inventory (both foreign and domestic) would be transferred to SRS which represents a total of 15.0 MTHM additional spent fuels. The same three disposition cases as the decentralization option were considered.

\section{Option 4 - Regionalization}

This option has all the DOE spent fuel inventory transferred between sites so that the entire DOE aluminum clad spent fuel inventory is the responsibility of SRS; all the SRS special clad spent fuels are transferred to other sites. The same three disposition cases were evaluated for only the aluminum clad spent fuel inventory.

\section{eption 5 - Centralization}

All the DOE spent fuels are transferred to SRS. Each of the above three disposition cases was evaluated for treatment of the entire DOE spent fuel inventory.

One additional disposition case is considered under this option, centralization at another site. In this case, all the SRS spent fuel and targets are shipped to another site for disposition.

Figure 1 portrays a generic overall flowsheet of all possible disposition/management cases. Various options/cases use one or more of the pathways possible, with a combination of existing and new facilities. The flowsheet combinations are described for each case in Section 4.

The processing cases presented are generally assumed to be conventional, proven technology using the PUREX or HM process to standard end state. Many variations of this scheme are possible including the placement of all nuclear materials into waste; vitrification to waste forms; denaturation of the weapons materials; and many others, but are not considered. Specific process analysis will be conducted in site specific NEPA/EIS actions. 
Technical Data Summary Supporting the INEL spent Fuel EIS Document No. NMP-PLS-930182, Revision 2

Marah 22, 1294

\section{FIGURE 1}

OVERALL FLOW CHART

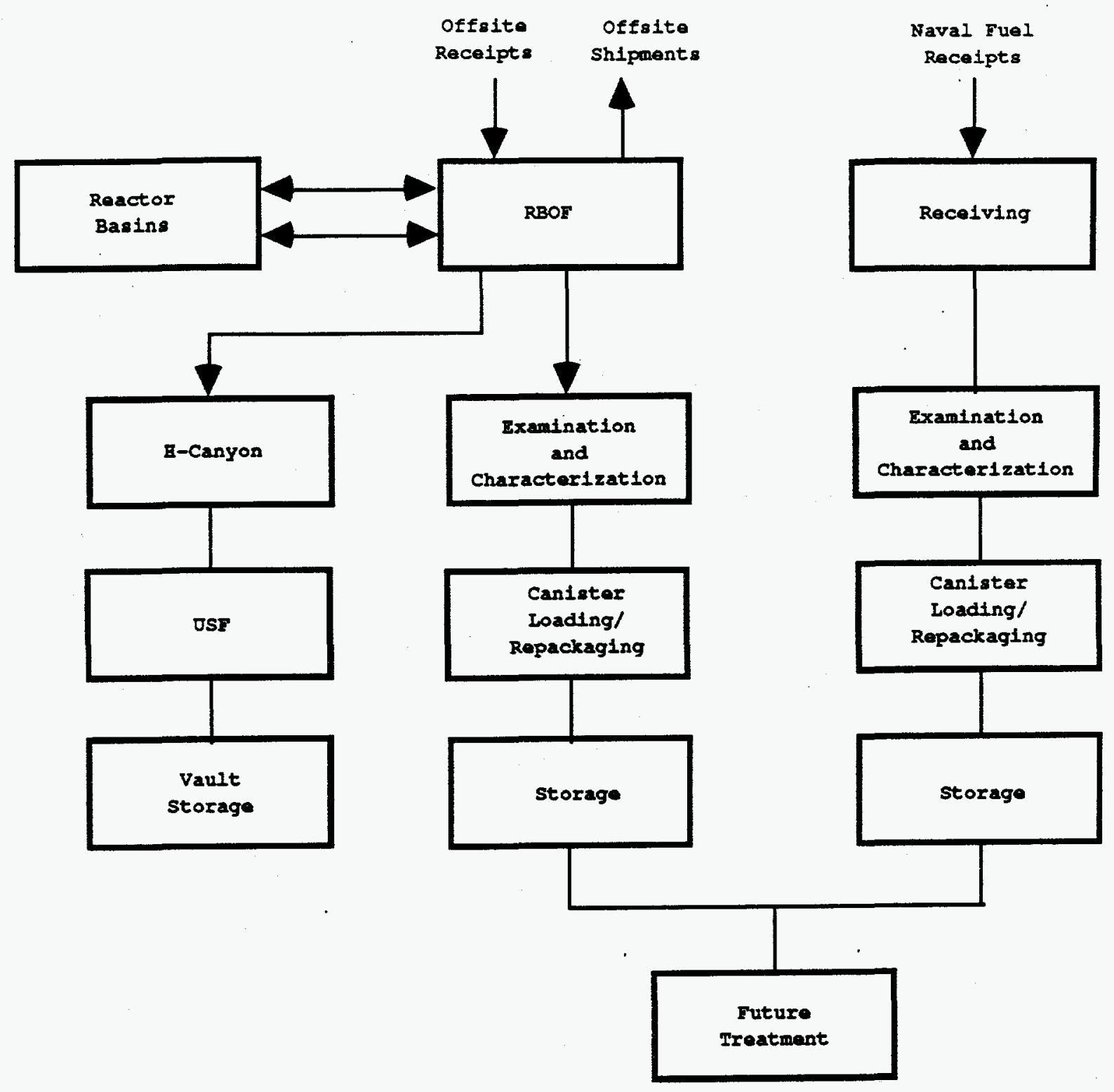




\section{SECTION 3}

\section{METHODOLOGY OF ANALYSIS \\ AND \\ COSTING BASIS}


Section 3

Technical Data summary supporting the INEL spent guel EIS

Document No. NMP-PIS-930182, Revision 2

Yarch $22, \quad 1994$

\section{Section 3 - Methodology of Analysis and Costing Basis}

The case analyses were prepared by first defining a selection of modular units consisting of both existing and proposed facilities (See Section 5). Each module was described with the key operating and environmental parameters estimated from available related data.

Due to limited time available for this study, essentially all data represents the best engineering judgment of the experienced personnel of the WSRC NMPD Planning Section. There is little documented basis or calculations to support the data presented.

These modules are combined as described in the case summaries of Section 4 to assemble a spent fuel disposition scenario. Twelve scenarios have been developed and presented in section 4. Numerous others could be envisioned as combinations and subsets of those presented (such as storing some fuels and processing others, rather than the total process or total store options presented).

All dollar figures presented are in FY-94 dollars. With spent fuel management scenarios extending over forty years, significant effects could be expected from a time phased, present value analysis. In general, the costing and environmental impact analysis of the various scenarios is performed differently for existing and new facilities.

For existing facilities, costs, wastes, and emissions were estimated on an incremental basis above a surveillance and maintenance mode for the facility. It is felt that this was the proper way to analyze the impact of the proposed actions. Proposed new facilities would be constructed as a result of specific mission guidance, therefore they are dedicated to the support of that mission. Thus, that mission must absorb the full cost and full environmental impact of that facility.

The construction of new facilities or processes carries with it the future liability to decommission and dismantle (D\&D) what has been built. This liability is shown as an projected cost in the final years of its mission function. Existing facilities do not carry this future cost, as this future liability has already been established - only the timing may be affected by spent fuel disposition decisions. This liability for existing facilities is not relevant to the decision process regarding disposition options. 
Page 9 of 170

Section 3

Technical Data Summary Supporting the INEL Spent Fuel EIS

Document No. NMP-PIS-930182, Revision 2

March $22, \quad 2924$

All cases involving long term storage of the spent fuels (Cases b and c) have a capital charge spread over a reasonable time period starting at the appropriate time to complete the necessary treatment prior to final disposal. Since all of these fuels have characteristics (e.g., SNM content, criticality potential, and/or cladding material) which make them unsuitable for geologic disposal without extensive treatment. Therefore, a fixed charge has been imposed to represent the undefined but probable high cost of a final disposal treatment facility.

The operational costs for this facility have been added to each applicable case summary. The total operational cost includes research and development, project, startup, and production costs. 
Section 4

Technical Data summary supporting the INEL spent Fuel aIs

Document No. NMP-PLS-930182, Revision 2

March 22. 1924

\title{
SECTION 4
}

\author{
CASE \\ SUMMARIES
}


Section 4

Technical Data Summary Supporting the INEL spent Fuel EIS

Document No. NMP-PLS-930182, Revision 2

varch 22. 1924

\section{OPTION 1 - NO ACTION}

Use existing SRS facilities and capabilities to provide extended storage of the SRS spent fuel and target inventory. No offsite shipments or receipts are considered in the option. Onsite consolidation and rearrangement of spent fuels will be performed.

SPENT FUEL INVENTORY DESCRIPTION:

Type 2 SRS reactor spent fuels (HEU/AI Clad) including the Pu targets - 183.6 MTHM

Type 6a Research reactor Stainless Steel Clad (HEU/LEU) - 11.3 MTHM

Type 6b Research reactor Zircaloy Clad (HEU/LEU) - 11.8 MTHM 
Section 4

Technical Data Summary Supporting the INEL Spent Fuel EIS

Document No. NMP-PLS-930182, Revision 2

March $22 \quad 1994$

Case 1 - SRS will store the current spent fuel inventories in existing facilities. No receipts or shipments are considered. The current spent fuel inventory will be rearranged to place the aluminum clad spent fuels in RBOF.

\section{ACTIVITY DESCRIPTION:}

SRS will process the solution inventories and other materials as required for safety. SRS will initiate the various programs and activities necessary to optimize and minimize the use of existing fuel storage facilities for extended interim storage of the existing site inventories. The goal of this program is to relocate aluminum clad spent fuels into the RBOF facility where excellent water quality will prolong the storage life of these fuels. Stainless steel (SST) and Zircaloy (Zr) clad spent fuels will be relocated to a reactor basin where the more resistant cladding can be expected to maintain spent fuel containment for an extended period.

FY-94 The DOE will initiate the EIS process: (1) to support interim storage of all SRS spent fuels in one reactor basin and RBOF, and (2) to support the reprocessing of the solution inventory and other materials as required for safety.

FY-95 The DOE will complete the EIS process by issuing the Record of Decision (ROD) which will allow SRS to proceed with the proposed activities.

FY-96 SRS will start reprocessing the solution inventories along with any other materials as required for safety.

SRS will start the rearrangement program for the aluminum clad fuels. SRS will renovate a selected reactor basin to improve water quality.

FY-97 At the completion of the program to renovate the selected reactor basin, SRS will relocate the SST/Zr clad spent fuels in the SRS inventory from $R B O F$ to that reactor basin. As SST/Zr assemblies are transferred to the reactor basin, these positions in $R B O F$ will be backfilled with aluminum clad fuels temporarily stored in the other reactor basins.

SRS will complete all reprocessing operations. Flushing and cleanout activities will commence. 
FY-98 All the aluminum clad spent fuels will be consolidated in RBOF; all SST/Zr fuels will be stored in a renovated reactor basin. The spent fuel storage facilities will placed in a $S \& M$ mode.

FY-00 All SRS separations facilities will be in the S\&M mode.

FY-10 Corrosion of the aluminum clad fuels in wet storage becomes severe. Additional personnel are added as the ever increasing number of failed spent fuels requires some type of operations to prevent environmental releases.

FY-15 SRS will initiate the R\&D program necessary to obtain the final disposal of the SRS spent fuel inventory.

FY-20 Based on the R\&D program recommendations, SRS will initiate a Congressional Iine Item project to design, construct, operate the final treatment facility.

FY-22 The Conceptual Design Report (CDR) for this project will be completed.

FY-24 Congress will authorize the project.

FY-25 The design and construction activities will begin.

FY-27 Preparation for the startup activities will commence.

FY-29 Construction will be completed. Startup activities will begin.

FY-31 After all the readiness reviews are satisfactorily completed, the facility will start operations.

FY-33 Processing the spent fuels into the final disposition form will be completed. The flushing and cleanout activities will begin.

FY-35 The final disposition treatment facility will be placed into the $S \& M$ mode. 
EACIIITIES USED IN THIS CASE:

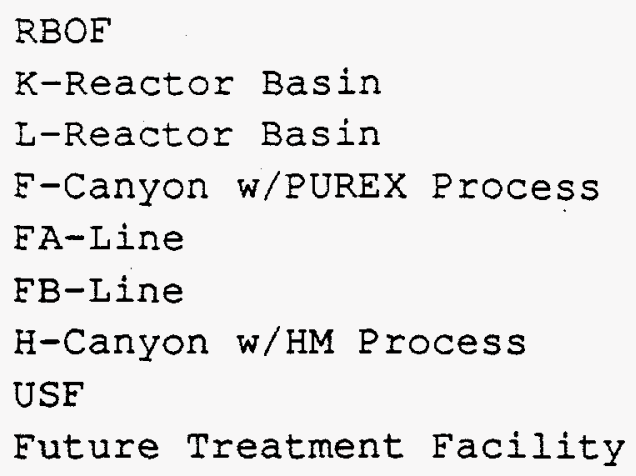

OPEN ISSUES :

Acceptable resolution of the EIS process for the interim wet storage of the current inventory of SRS spent fuels. This includes public acceptance of the interim storage in existing basins which do not meet current DOE or nuclear industry standards for spent fuel storage facilities.

Due to the corrosion of aluminum clad spent fuels in water, this case is not considered to be technically viable beyond the FY-10 time frame.

This scenario is an interim storage option only. Further treatment (processing) will be required to obtain a disposable waste form, but is not considered in this option. 

Technical Data Sumary Supporting tho INEL Spent Fuel EIS.
Document No. MMP-PLS-930182, Revision 2

March 22, 1924

\section{FIGURE 2}

FIOW CHART FOR CASE 1

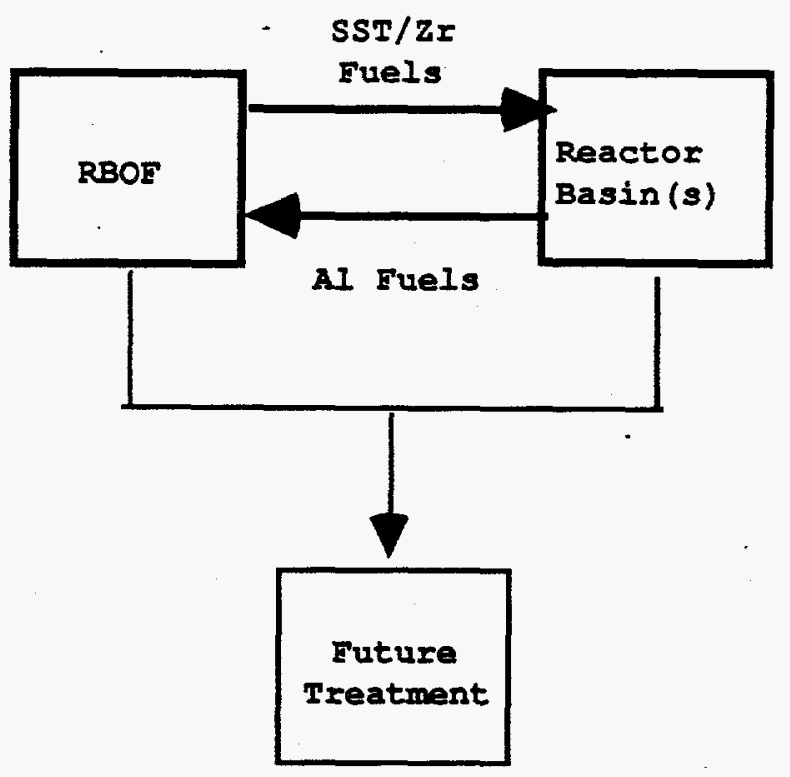


Section 4

Technical Data sumary supporting the INEI spent ruel EIS

Document No. NMP-PIS-930182, Revision 2

March $22, \quad 2994$

TABLE 1

PERSONNEL AND COST DATA FOR CASE 1

\begin{tabular}{|c|c|c|c|c|c|}
\hline \multirow[t]{2}{*}{ YEAR } & \multicolumn{2}{|c|}{ PERSONNEL } & \multicolumn{2}{|c|}{$\begin{array}{c}\text { FONDING } \\
\text { (\$M11110ns) } \\
\end{array}$} & \multirow[t]{2}{*}{$\begin{array}{c}\text { OTILITY COST } \\
\text { (\$MIIIIOns) }\end{array}$} \\
\hline & CARITAI & OPERATIONS & CAPITAL & OPERATIONS & \\
\hline 1994 & 100 & 4,960 & 10.0 & 374.0 & 28.0 \\
\hline 1995 & 90 & 4,770 & 9.0 & 367.0 & 28.0 \\
\hline 1996 & 80 & 4.670 & 8.0 & 367.0 & 28.0 \\
\hline 1997 & 70 & 4.100 & 7.0 & 330.0 & 28.0 \\
\hline 1998 & 60 & 3,530 & 6.0 & 289.0 & 22.0 \\
\hline 1999 & 60 & 2,780 & 6.0 & 233.0 & 22.0 \\
\hline 2000 & 60 & 2,610 & 6.0 & 224.0 & 22.0 \\
\hline 2001 & 60 & 2,610 & 6.0 & 229.0 & 22.0 \\
\hline 2002 & 60 & 2,610 & 7.0 & 234.0 & 22.0 \\
\hline 2003 & 50 & 2,610 & 7.0 & 240.0 & 23.0 \\
\hline 2004 & 60 & 2,610 & 7.0 & 245.0 & 23.0 \\
\hline 2005 & 60 & 2,610 & 7.0 & 250.0 & 23.0 \\
\hline 2006 & 60 & 2,610 & 7.0 & 256.0 & 23.0 \\
\hline 2007 & 60 & 2,610 & 7.0 & 261.0 & 23.0 \\
\hline 2008 & 60 & 2,610 & 7.0 & 267.0 & 23.0 \\
\hline 2009 & 60 & 2,610 & 8.0 & 273.0 & 24.0 \\
\hline 2010 & 60 & 2,610 & 8.0 & 279.0 & 24.0 \\
\hline 2011 & 60 & 2,650 & 8.0 & 289.0 & 24.0 \\
\hline 2012 & 60 & 2,650 & 8.0 & 296.0 & 24.0 \\
\hline 2013 & 60 & 2,720 & 8.0 & 309.0 & 24.0 \\
\hline 2014 & 60 & 2,720 & 8.0 & 316.0 & 25.0 \\
\hline 2015 & 60 & 2,780 & 9.0 & 330.0 & 25.0 \\
\hline 2016 & 60 & 2,780 & 9.0 & 337.0 & 25.0 \\
\hline 2017 & 60 & 2,850 & 9.0 & 393.0 & 25.0 \\
\hline 2018 & 60 & 2,850 & 9.0 & 400.0 & 25.0 \\
\hline 2019 & 60 & 2,850 & 9.0 & 418.0 & 26.0 \\
\hline 2020 & 60 & 2,920 & 10.0 & 445.0 & 26.0 \\
\hline 2021 & 60 & 2,910 & 10.0 & 453.0 & 26.0 \\
\hline 2022 & 60 & 2,590 & 10.0 & 412.0 & 26.0 \\
\hline 2023 & 60 & 2,590 & 10.0 & 420.0 & 26.0 \\
\hline 2024 & 60 & 2,640 & 11.0 & 439.0 & 27.0 \\
\hline 2025 & 60 & 2,640 & 11.0 & 449.0 & 27.0 \\
\hline 2026 & 550 & 2,640 & 111.0 & 458.0 & 30.0 \\
\hline 2027 & 1.030 & 2,640 & 211.0 & 468.0 & 30.0 \\
\hline 2028 & 1,490 & 2,690 & 312.0 & 488.0 & 30.0 \\
\hline 2029 & 1,460 & 2,740 & 312.0 & 508.0 & 30.0 \\
\hline 2030 & 510 & 2,940 & 112.0 & 558.0 & 30.0 \\
\hline 2031 & 60 & 2,690 & 12.0 & 589.0 & 40.0 \\
\hline 2032 & 60 & 3,040 & 13.0 & 599.0 & 40.0 \\
\hline 2033 & 60 & 3,040 & 13.0 & 612.0 & 40.0 \\
\hline 2034 & 60 & 3,040 & 13.0 & 626.0 & 40.0 \\
\hline 2035 & 1,000 & 3,040 & 313.0 & 640.0 & 35.0 \\
\hline
\end{tabular}


Technical Data Summary Supporting the INEL Spent Fuel EIS

Document No. NMP-PLS-930182, Revision 2

Narch $22, \quad 1994$

\section{OPTION 2 - DECENTRALIZATION}

SRS will manage its existing spent fuel inventory without any consideration for offsite shipments or receipts. Onsite consolidation and rearrangement of the spent fuels will be performed in the two storage cases. Alternative wet and dry storage cases will be considered, while the reprocessing case applies to only the existing SRS aluminum clad spent fuels.

SPENT FUEL INVENTORY DESCRIPTION:

Type 2 SRS reactor spent fuels (HEU/AI Clad) plus the Pu targets (DU/ Al clad) - $183.6 \mathrm{MTHM}$

Type 6a Research reactor SST clad (HEU/LEU) - 11.3 MTHM

Type 6b Research reactor $\mathrm{Zr}$ clad (HEU/LEU) - $11.8 \mathrm{MTHM}$ 
Saction 4

Technlcal Data Summary Supporting the INEI spent ruel eIS

Document Ho. MXP-PLS-930182, Revision 2

Varch 23, 1924

TABIE 2

WASTE AND EMISSIONS DATA FOR CASE 1

\begin{tabular}{|c|c|c|c|c|c|c|}
\hline \multirow[t]{2}{*}{ YEAR } & \multicolumn{5}{|c|}{ RASTE VOLOMES } & \multirow[t]{2}{*}{ IMISSIONS } \\
\hline & $\begin{array}{c}\text { CAEISTER } \\
\text { (qty.) }\end{array}$ & $\begin{array}{c}\text { SALTCRETE } \\
\text { (cu yds) }\end{array}$ & $\begin{array}{c}\mathrm{II} \\
(\mathrm{cu} f t)\end{array}$ & $\begin{array}{c}\text { SAXITARY } \\
\text { (Kgal) }\end{array}$ & $\begin{array}{c}\text { TRO } \\
\text { (cu yds) }\end{array}$ & \\
\hline 1994 & 0 & 0 & 45,000 & 60,720 & 57 & slight \\
\hline 1995 & 0 & 0 & 45,000 & 58,320 & 57 & slight \\
\hline 1996 & 5 & 1,500 & 59,000 & 57,000 & 60 & slight \\
\hline 1997 & 6 & 1,500 & 59,000 & 50,040 & 60 & slight \\
\hline 1998 & 0 & 0 & 45,000 & 43,080 & 57 & slight \\
\hline 1999 & 0 & 0 & 45,000 & 34,080 & 57 & slight \\
\hline 2000 & 0 & 0 & 20,000 & 32,040 & 57 & slight \\
\hline 2001 & 0 & 0 & 20,000 & 32,040 & 57 & slight \\
\hline 2002 & 0 & 0 & 20,000 & 32,040 & 57 & slight \\
\hline 2003 & 0 & 0 & 20,000 & 32,040 & 57 & slight \\
\hline 2004 & 0 & 0 & 20,000 & 32,040 & 57 & slight \\
\hline 2005 & 0 & 0 & 20,000 & 32,040 & 57 & slight \\
\hline 2006 & 0 & 0 & 20,000 & 32,040 & 57 & slight \\
\hline 2007 & 0 & 0 & 20,000 & 32,040 & 57 & slight \\
\hline 2008 & 0 & 0 & 20,000 & 32,040 & 57 & slight \\
\hline 2009 & 0 & 0 & 20,000 & 32,040 & 57 & slight \\
\hline 2010 & 0 & 0 & 20,000 & 32,040 & 57 & slight \\
\hline 2011 & 0 & 0 & 20,000 & 32,520 & 57 & slight \\
\hline 2012 & 0 & 0 & 20,000 & 32,520 & 57 & slight \\
\hline 2013 & 0 & 0 & 20,000 & 33,360 & 57 & slight \\
\hline 2014 & 0 & 0 & 20,000 & 33,360 & 57 & slight \\
\hline 2015 & 0 & 0 & 20,000 & 34,080 & 57 & slight \\
\hline 2016 & 0 & 0 & 20,000 & 34,080 & 57 & slight \\
\hline 2017 & 0 & 0 & 20,000 & 34,920 & 57 & slight \\
\hline 2018 & 0 & 0 & 20,000 & 34,920 & 57 & slight \\
\hline 2019 & 0 & 0 & 20,000 & 34,920 & 57 & slight \\
\hline 2020 & 0 & 0 & 20,000 & 35,760 & 57 & slight \\
\hline 2021 & 0 & 0 & 20,000 & 35,640 & 57 & slight \\
\hline 2022 & 0 & 0 & 20,000 & 31,800 & 57 & slight \\
\hline 2023 & 0 & 0 & 20,000 & 32,400 & 57 & slight \\
\hline 2024 & 0 & 0 & 20,000 & 32,400 & 57 & slight \\
\hline 2025 & 0 & 0 & 20,000 & 32,400 & 57 & slight \\
\hline 2026 & 0 & 0 & 20,000 & 38,280 & 57 & slight \\
\hline 2027 & 0 & 0 & 20,000 & 44,640 & 57 & slight \\
\hline 2028 & 0 & 0 & 20,000 & 50,760 & 57 & slight \\
\hline 2029 & 0 & 0 & 20,000 & 52,800 & 57 & slight \\
\hline 2030 & 24 & 6,500 & 114,000 & 42,480 & 57 & slight \\
\hline 2031 & 24 & 6,500 & 114,000 & 37,200 & 60 & slight \\
\hline 2032 & 24 & 6,500 & 114,000 & 37,080 & 60 & slight \\
\hline 2033 & 0 & 0 & 45,000 & 37,080 & 60 & slight \\
\hline 2034 & 0 & 0 & 45,000 & 37,080 & 57 & slight \\
\hline 2035 & 0 & 0 & 45,000 & 48,360 & 57 & slight \\
\hline
\end{tabular}


Technlcal Data summary supporting the INEL spent Fuel EIS

Document No. NMP-PLS-930182, Revision 2

Marab 22, 1294

DECENTRALIZATION

Case $2 a$ - Process all the SRS aluminum clad spent fuels and Pu targets to stabilize the sNM for vault storage. Provide interim storage for the special clad spent fuels in new dry storage facilities.

ACTIVITY DESCRIPTION:

The SRS separations facilities will be used to process the SRS aluminum clad spent fuel inventory to safe, stable, consolidated forms for storage in a product storage vault.

The F-Area separations facilities will be used to process the Pu targets. The Pu targets will be dissolved, then purified in the F-Canyon Facility. The resulting solutions will be processed in the FB-Line Facility to produce Pu metal, while the DU will be converted to oxide in the FA-Iine Facility.

The SRS aluminum clad spent fuels will be reprocessed in $\mathrm{H}$-Area using the HM process for aluminum clad fuels. The highly enriched uranium product (HEU) will be converted to an oxide in the Uranium Solidification Facility (USF).

New dry storage facilities will be constructed for the interim dry storage of the special clad spent fuels.

The sequence of events for this case is as follows:

$$
\text { E-Area }
$$

H-Area

FY-94 Initiate the EIS process to permit the processing of the Pu targets and solutions.

FY-95 The DOE will complete the EIS process by issuing the ROD to permit processing of the Al clad spent and the dry storage of the special clad fuels

FY-96 Begin processing the Pu targets and solutions.
Initiate the EIS process to permit: (1) the processing of the Al clad spent fuels and solutions, and (2) dry storage of the special clad spent fuels.

The DOE will complete the EIS process by issuing the ROD to permit processing of the $A l$ clad spent and the dry storage of the special clad fuels.

Begin processing of SRS aluminum clad fuel from the reactor basins. 


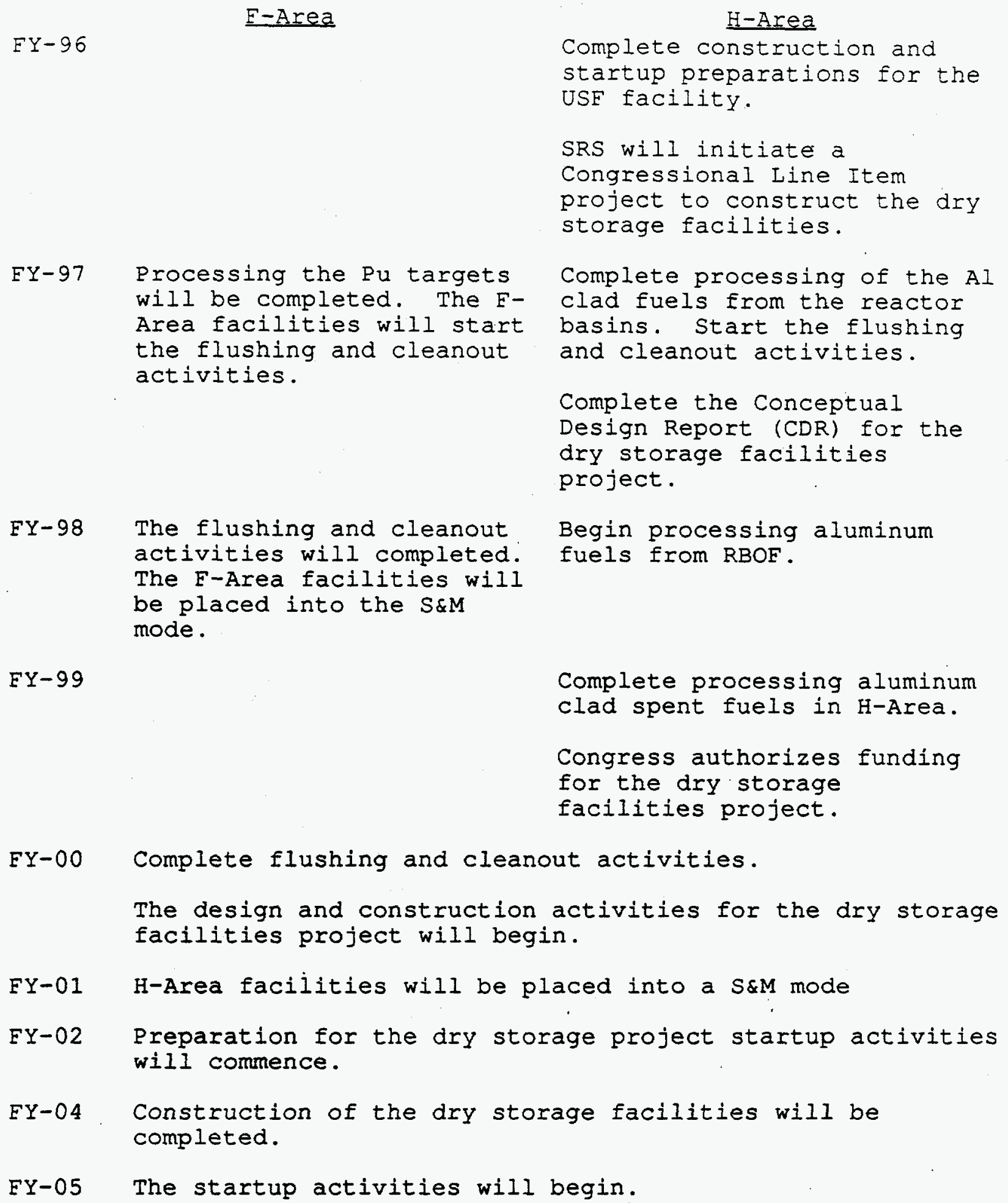


Technical Data Summary Supporting the INEL spent fuel EIS Document No. NMP-PLS-930182, Revision 2

March 22, 1294

FY-06 After all the readiness reviews are satisfactorily completed, the dry storage facilities will begin operations.

FY-08 All the special clad fuel will placed into dry storage. The dry storage facilities will be placed into the $S \& M$ mode which includes monitoring and examining activities.

FY-21 SRS will initiate the R\&D program necessary to obtain the final disposal of the SRS inventory of spent fuels.

EY-24 Based on the R\&D program recommendations, SRS will initiate a Congressional Line Item project to design, construct, and operate the final treatment facility.

FY-25 The CDR for this project will be completed.

FY-27 Congress will authorize the project.

FY-28 Design and construction activities will begin.

FY-30 Preparation for the startup activities will commence.

FY-32 Construction will be completed.

Startup activities will begin.

EY-33 After all the readiness reviews are satisfactorily completed, the facility will start operations.

FY-34 Processing the spent fuels into the final disposition form will be completed. The flushing and cleanout activities will begin.

FY-35 The facility will be placed into a S\&M mode. 


\section{EACILITIES USED IN THIS CASE:}

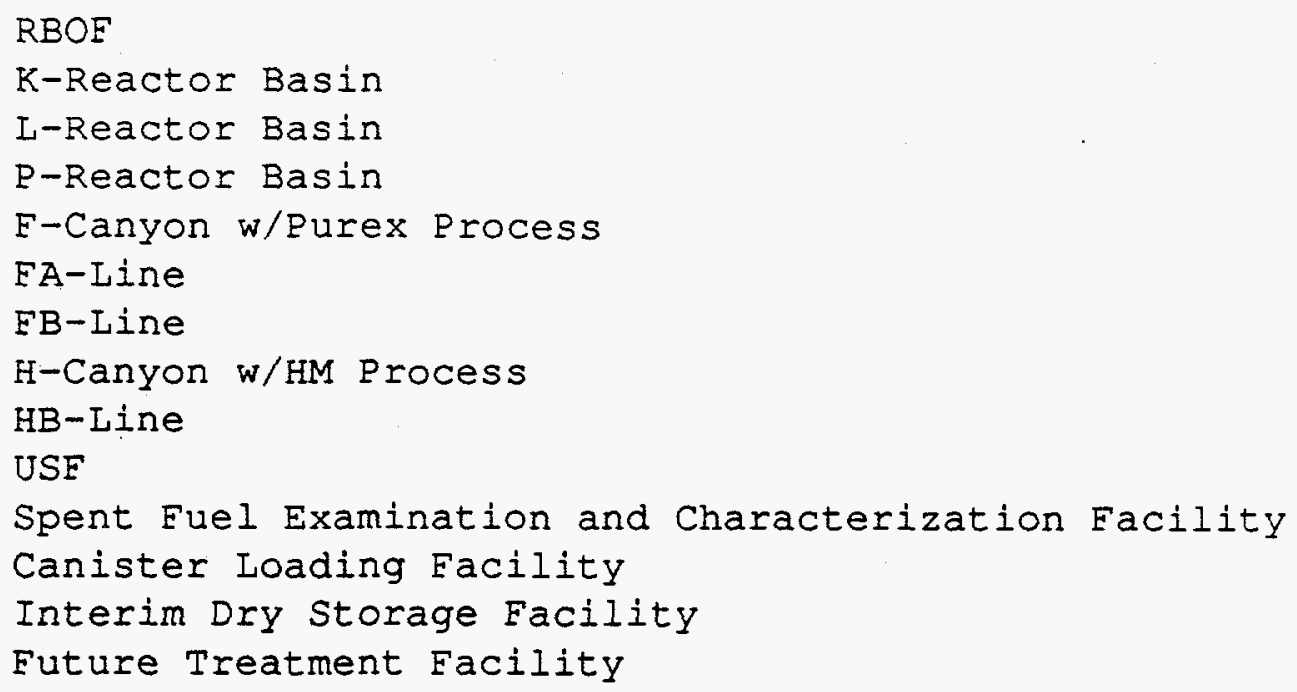

OPEN ISSUES :

Acceptable resolution of the EIS process to resume the processing operations in $F$ and $H$ Areas and the interim dry storage of spent fuels.

It is assumed that special scientific isotopes contained in the spent fuels will not be recovered.

Significant capital funding is required to provide the necessary new facilities including the $D \& D$ of them.

Large annual operating budgets are required for the facilities including an R\&D program for the future treatment facility. 
Section

Technical Data Summary Supporting the INEL spent fuel EIS

Document No. MMP-PLS-930182, Revision 2

March 22, 1994

\section{EIGURE 3}

FLOW CHART FOR CASE 2 a

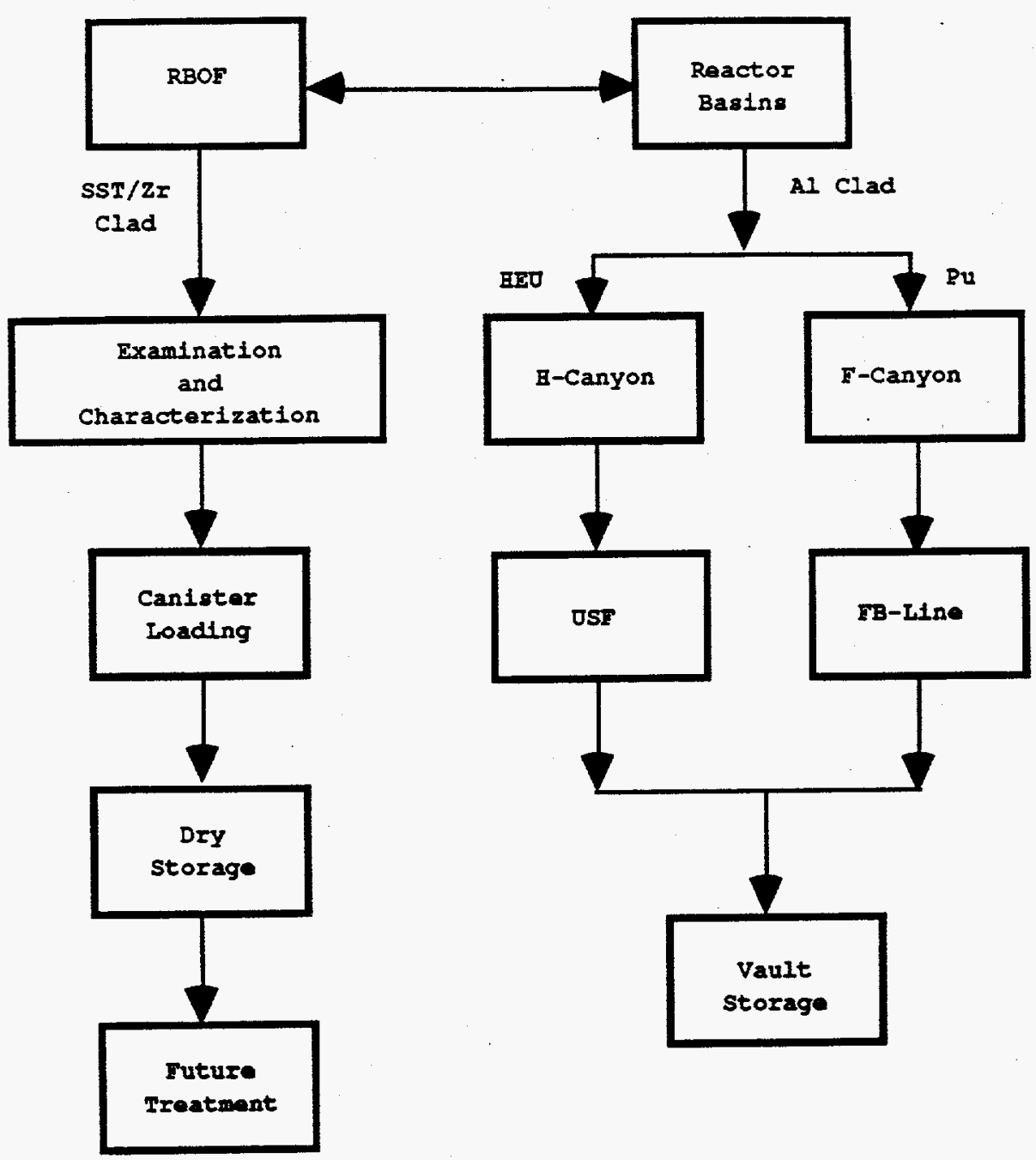


Section 4

Technical Data Summary Supporting the INEL spent ruel eIS

Document No. NMP-PLS-930182, Revision

Narch 22_ 1994

TABLE 3

COST DATA FOR CASE 2a

\begin{tabular}{|c|c|c|c|c|c|}
\hline YEAR & \multicolumn{2}{|c|}{ PERSONNEL } & \multicolumn{2}{|c|}{$\begin{array}{c}\text { FUNDING } \\
\text { (\$MIIIIOns) } \\
\end{array}$} & $\begin{array}{c}\text { OTILITY COST } \\
\text { (\$MIIIIOns) }\end{array}$ \\
\hline & CAPITAL & OPERATIONS & CAP ITAL & OPERATIONS & \\
\hline 1994 & 100 & 4,960 & 10.0 & 374.0 & 28.0 \\
\hline 1995 & 90 & 4,820 & 9.0 & 371.0 & 28.0 \\
\hline 1996 & 80 & 4,780 & 8.0 & 372.0 & 28.0 \\
\hline 1997 & 70 & 4,110 & 7.0 & 331.0 & 28.0 \\
\hline 1998 & 60 & 3,790 & 6.0 & 313.0 & 21.0 \\
\hline 1999 & 60 & 3,060 & 6.0 & 258.0 & 21.0 \\
\hline 2000 & 360 & 2,350 & 41.0 & 203.0 & 21.0 \\
\hline 2001 & 700 & 2,350 & 81.0 & 207.0 & 16.0 \\
\hline 2002 & 1.060 & 2,440 & 127.0 & 220.0 & 16.0 \\
\hline 2003 & 960 & 2,720 & 117.0 & 250.0 & 16.0 \\
\hline 2004 & 300 & 2,950 & 37.0 & 277.0 & 16.0 \\
\hline 2005 & 60 & 3,150 & 7.0 & 303.0 & 18.0 \\
\hline 2006 & 60 & 3,150 & 7.0 & 310.0 & 18.0 \\
\hline 2007 & 60 & 3,150 & 7.0 & 316.0 & 18.0 \\
\hline 2008 & 60 & 3,040 & 7.0 & 311.0 & 18.0 \\
\hline 2009 & 140 & 2,850 & 8.0 & 299.0 & 17.0 \\
\hline 2010 & 140 & 2,850 & 8.0 & 306.0 & 17.0 \\
\hline 2011 & 140 & 2,850 & 8.0 & 313.0 & 17.0 \\
\hline 2012 & 60 & 2,850 & 8.0 & 319.0 & 17.0 \\
\hline 2013 & 60 & 2.850 & 8.0 & 327.0 & 17.0 \\
\hline 2014 & 60 & 2,850 & 8.0 & 334.0 & 18.0 \\
\hline 2015 & 60 & 2,850 & 9.0 & 341.0 & 18.0 \\
\hline 2016 & 60 & 2,850 & 9.0 & 349.0 & 18.0 \\
\hline 2017 & 60 & 2.850 & 9.0 & 356.0 & 18.0 \\
\hline 2018 & 60 & 2,850 & 9.0 & 364.0 & 18.0 \\
\hline 2019 & 60 & 2,850 & 9.0 & 410.0 & 18.0 \\
\hline 2020 & 60 & 2,850 & 10.0 & 418.0 & 19.0 \\
\hline 2021 & 60 & 2,910 & 10.0 & 436.0 & 19.0 \\
\hline 2022 & 60 & 2.840 & 10.0 & 435.0 & 19.0 \\
\hline 2023 & 60 & 2.770 & 10.0 & 434.0 & 19.0 \\
\hline 2024 & 60 & 2,670 & 11.0 & 427.0 & 19.0 \\
\hline 2025 & 60 & 2,660 & 11.0 & 434.0 & 20.0 \\
\hline 2026 & 60 & 2,670 & 11.0 & 447.0 & 20.0 \\
\hline 2027 & 60 & 2,660 & 11.0 & 454.0 & 20.0 \\
\hline 2028 & 300 & 2.650 & 62.0 & 461.0 & 25.0 \\
\hline 2029 & 520 & 2,660 & 112.0 & 474.0 & 25.0 \\
\hline 2030 & 740 & 2.700 & 162.0 & 492.0 & 25.0 \\
\hline 2031 & 730 & 2,810 & 162.0 & 523.0 & 25.0 \\
\hline 2032 & 270 & 2.840 & 63.0 & 541.0 & 25.0 \\
\hline 2033 & 60 & 2,810 & 13.0 & 546.0 & 35.0 \\
\hline 2034 & 60 & 2,790 & 13.0 & 555.0 & 35.0 \\
\hline 2035 & 870 & 2,720 & 208.0 & 553.0 & 35.0 \\
\hline
\end{tabular}


Section 4

Technical Data Summary Supporting the INEL spent Fuel EIS

Document No. NMP-PLS-930182, Revision 2

Narch 22, 2924

TABLE 4

WASTE AND EMISSIONS DATA FOR CASE 2 a

\begin{tabular}{|c|c|c|c|c|c|c|}
\hline YEAR & \multicolumn{5}{|c|}{ MASTE VOLOMES } & EMISSIONS \\
\hline & $\begin{array}{c}\text { CANISTER } \\
\text { (Gty.) }\end{array}$ & $\begin{array}{c}\text { SALTCRETE } \\
\text { (cu yds) }\end{array}$ & $\begin{array}{c}\mathrm{LI} \\
(\mathrm{cu} f t)\end{array}$ & $\begin{array}{c}\text { SANI TARY } \\
\text { (Kgal) }\end{array}$ & $\begin{array}{c}\text { TRO } \\
\text { (cu yds) }\end{array}$ & \\
\hline 1994 & 0 & 0 & 45,000 & 60,720 & 57 & slight \\
\hline 1995 & 0 & 0 & 45,000 & 58,920 & 57 & slight \\
\hline 1996 & 16 & 4,839 & 91,000 & 58,320 & 65 & slight \\
\hline 1997 & 17 & 4,839 & 91,000 & 50,160 & 65 & slight \\
\hline 1998 & 17 & 4,839 & 91,000 & 46,200 & 65 & slight \\
\hline 1999 & 17 & 4,839 & 91,000 & 37,440 & 65 & slight \\
\hline 2000 & 0 & 0 & 45,000 & 32,520 & 65 & slight \\
\hline 2001 & 0 & 0 & 20,000 & 36,600 & 57 & slight \\
\hline 2002 & 0 & 0 & 20,000 & 42,000 & 20 & slight \\
\hline 2003 & 0 & 0 & 20,000 & 44,160 & 20 & slight \\
\hline 2004 & 0 & 0 & 20,000 & 39,000 & 20 & slight \\
\hline 2005 & 0 & 0 & 20,000 & 38,520 & 20 & slight \\
\hline 2006 & 0 & 0 & 20,000 & 38,520 & 20 & slight \\
\hline 2007 & 0 & 0 & 20,000 & 38,520 & 20 & slight \\
\hline 2008 & 0 & 0 & 20,000 & 37,200 & 20 & slight \\
\hline 2009 & 0 & 0 & 20,000 & 35,880 & 20 & slight \\
\hline 2010 & 0 & 0 & 20,000 & 35,880 & 20 & slight \\
\hline 2011 & 0 & 0 & 20,000 & 35,880 & 20 & slight \\
\hline 2012 & 0 & 0 & 20,000 & 34,920 & 20 & slight \\
\hline 2013 & 0 & 0 & 20,000 & 34,920 & 20 & slight \\
\hline 2014 & 0 & 0 & 20,000 & 34,920 & 20 & slight \\
\hline 2015 & 0 & 0 & 20,000 & 34,920 & 20 & slight \\
\hline 2016 & 0 & 0 & 20,000 & 34,920 & 20 & slight \\
\hline 2017 & 0 & 0 & 20,000 & 34,920 & 20 & slight \\
\hline 2018 & 0 & 0 & 20,000 & 34,920 & 20 & slight \\
\hline 2019 & 0 & 0 & 20,000 & 34,920 & 20 & slight \\
\hline 2020 & 0 & 0 & 20,000 & 34,920 & 20 & slight \\
\hline 2021 & 0 & 0 & 20,000 & 35,640 & 20 & slight \\
\hline 2022 & 0 & 0 & 20,000 & 34,800 & 20 & slight \\
\hline 2023 & 0 & 0 & 20,000 & 33,960 & 20 & slight \\
\hline 2024 & 0 & 0 & 20,000 & 32,760 & 20 & slight \\
\hline 2025 & 0 & 0 & 20,000 & 32,640 & 20 & slight \\
\hline 2026 & 0 & 0 & 20,000 & 32,760 & 20 & slight \\
\hline 2027 & 0 & 0 & 20,000 & 32,640 & 20 & slight \\
\hline 2028 & 0 & 0 & 20,000 & 35,400 & 20 & slight \\
\hline 2029 & 0 & 0 & 20,000 & 38,160 & 20 & slight \\
\hline 2030 & 0 & 0 & 20,000 & 41,280 & 20 & slight \\
\hline 2031 & 0 & 0 & 20,000 & 42,480 & 20 & slight \\
\hline 2032 & 0 & 0 & 20,000 & 37,320 & 40 & slight \\
\hline 2033 & 7 & 900 & 65,000 & 34,440 & 45 & slight \\
\hline 2034 & 8 & 900 & 65,000 & 34,200 & 57 & slight \\
\hline 2035 & 0 & 0 & 20,000 & 43,080 & 20 & slight \\
\hline
\end{tabular}




\section{OPTION 2 - DECENTRAIIZATION \\ Case 2b - Provides for the interim wet storage of the existing sRs spent fuel inventory. Additional capabilities to monitor, examine, characterize, and repackage the spent fuels are provided.}

\section{ACTIVITY DESCRIPTION:}

The spent fuels are rearranged as in case 1 to provide temporary wet storage while new, complying facilities are constructed. The new wet storage facilities will meet all the DOE and NRC requirements for SNF and SNM storage.

Included in the new storage facilities are the capabilities to examine and characterize the spent fuels. All the spent fuels will be encapsulated in a stainless steel canister prior to placement in the pool.

This case will process the solutions presently stored in the canyon buildings as well as any materials as required for safety.

The sequence of events for this case are as follows:

FY-94 The DOE will initiate the EIS process to support: (1) temporary storage of spent fuels in one reactor basin and RBOF; (2) interim wet storage in new facilities; and (3) processing the solution inventory.

FY-95 The DOE will complete the EIS process by issuing the ROD permitting the proposed activities.

FY-96 SRS will initiate a Congressional Line Item Project for authorization in FY-00 to provide replacement wet storage facilities.

SRS will initiate a program to rearrange the spent fuels to reduce the potential for corrosion damage to the spent fuels, especially the aluminum clad ones. The program will start with the renovation of a reactor basin to improve water quality.

SRS will start processing the solutions and other materials as required for safety. 
FY-97 At the completion of the program to renovate the selected reactor basin, SRS will relocate the SST/Zr clad spent fuels in the SRS inventory from RBOF to that basin. As the SST/Zr assemblies are transferred to the selected reactor, these positions in RBOF will be backfilled with aluminum clad fuels from the other reactor basins.

Processing the solutions and other materials will be completed. The flushing and cleanout activities SRS chemical separation facilities will start.

The CDR for the replacement wet storage project will be completed.

FY-98 All aluminum clad spent fuels will be consolidated in RBOF; all SST/Zr fuels will be stored in an renovated reactor basin. The temporary wet storage facilities go to a S\&M mode for a 10-15 year period.

The separation facilities will be placed into a S\&M mode.

FY-99 The replacement spent fuel wet storage facilities project will be authorized.

FY-00 Design and construction of the replacement wet storage facilities will begin.

FY-02 Preparation for the startup activities will commence.

FY-04 Construction will be completed.

Startup activities will begin.

FY-06 After all readiness reviews have been satisfactorily completed, the facility operations will begin.

The aluminum clad spent fuels will be characterized, then repackaged into stainless steel containers prior to transfer to the new facility

FY-10 Transfer of the SNF to the new facility will be completed.

All the basins will be placed into the S\&M mode. For the new facilities, the $S \& M$ mode will include monitoring, examination and repackaging activities. 
FY-21 SRS will initiate the R\&D program necessary to obtain the final disposition of the SRS spent fuel inventory.

FY-24 Based on the R\&D program recommendations, SRS will initiate a Congressional Line Item project to design, construct, and operate the final disposition treatment facility.

FY-25 The CDR for this project will be completed.

FY-28 Congress will authorize the project.

FY-29 Design and construction activities will begin.

FY-27 Preparation for the project startup activities will commence.

FY-32 Construction will be completed.

Startup activities will begin.

FY-33 After all the readiness reviews are satisfactorily completed, the facility will start operations.

FY-34 Processing the spent fuels into the final disposition form will be completed. The flushing and cleanout activities will begin.

FY-35 The facility will be placed into the S\&M mode.

FACILITIES USED IN THIS CASE:

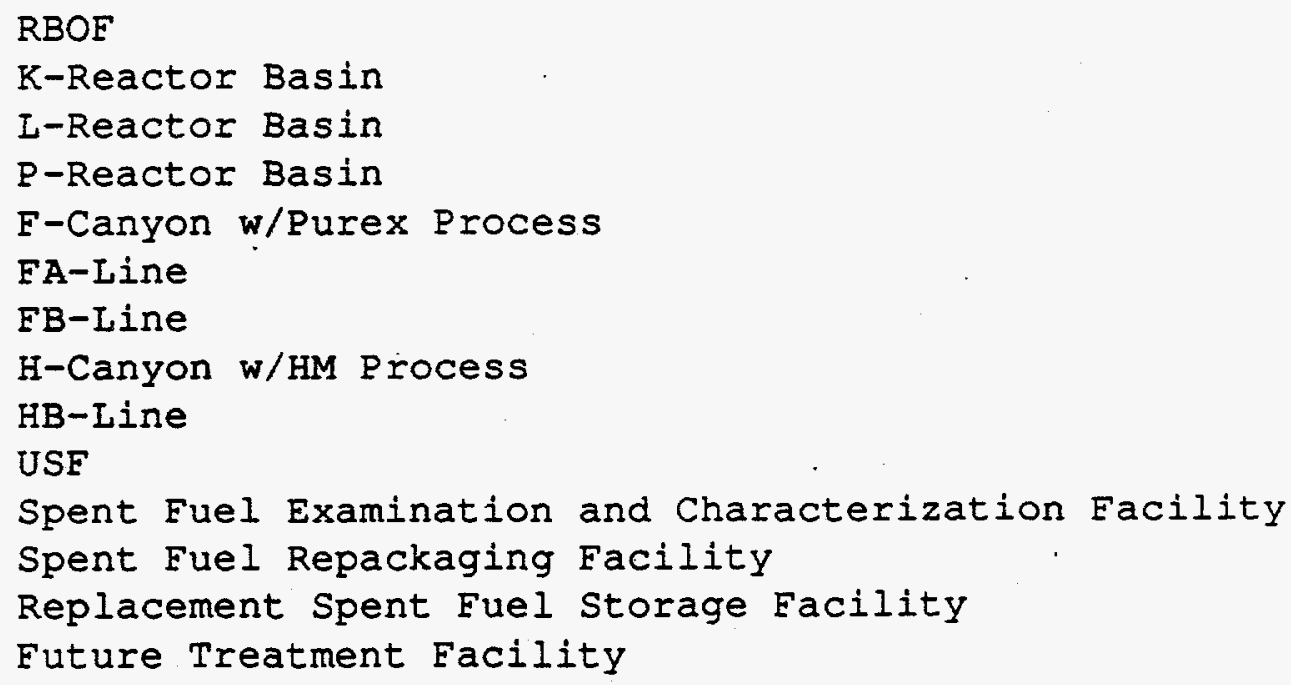


Section

Technical Data Sumary supporting the INEL spent Fuel EIS

Document No. NMP-PLS-930182, Revision 2

March 22,1294

\section{OPEN ISSUES :}

Acceptable resolution of the EIS process for the interim wet storage of the SRS spent fuel inventory and for the processing of the solutions and other materials as required for safety.

Wet storage of the SRS spent fuel inventory is an interim action. No disposition technology exists except some type of future treatment. The encapsulation necessary to contain aluminum clad spent fuels through the interim wet storage period makes future treatment more complex and costly.

Large capital expenditures are required to design, construct, operate, then $D \& D$ all the new facilities.

Large annual budgets are required to maintain the facilities, both new and old. 
Section 4

Technical Data Summary Supporting the INEL spent Fuel EIS

Document No. NMP-PLS-930182, Revision 2

March 22, 2924

\section{FIGURE 4}

FLOW CHART FOR CASE 2b

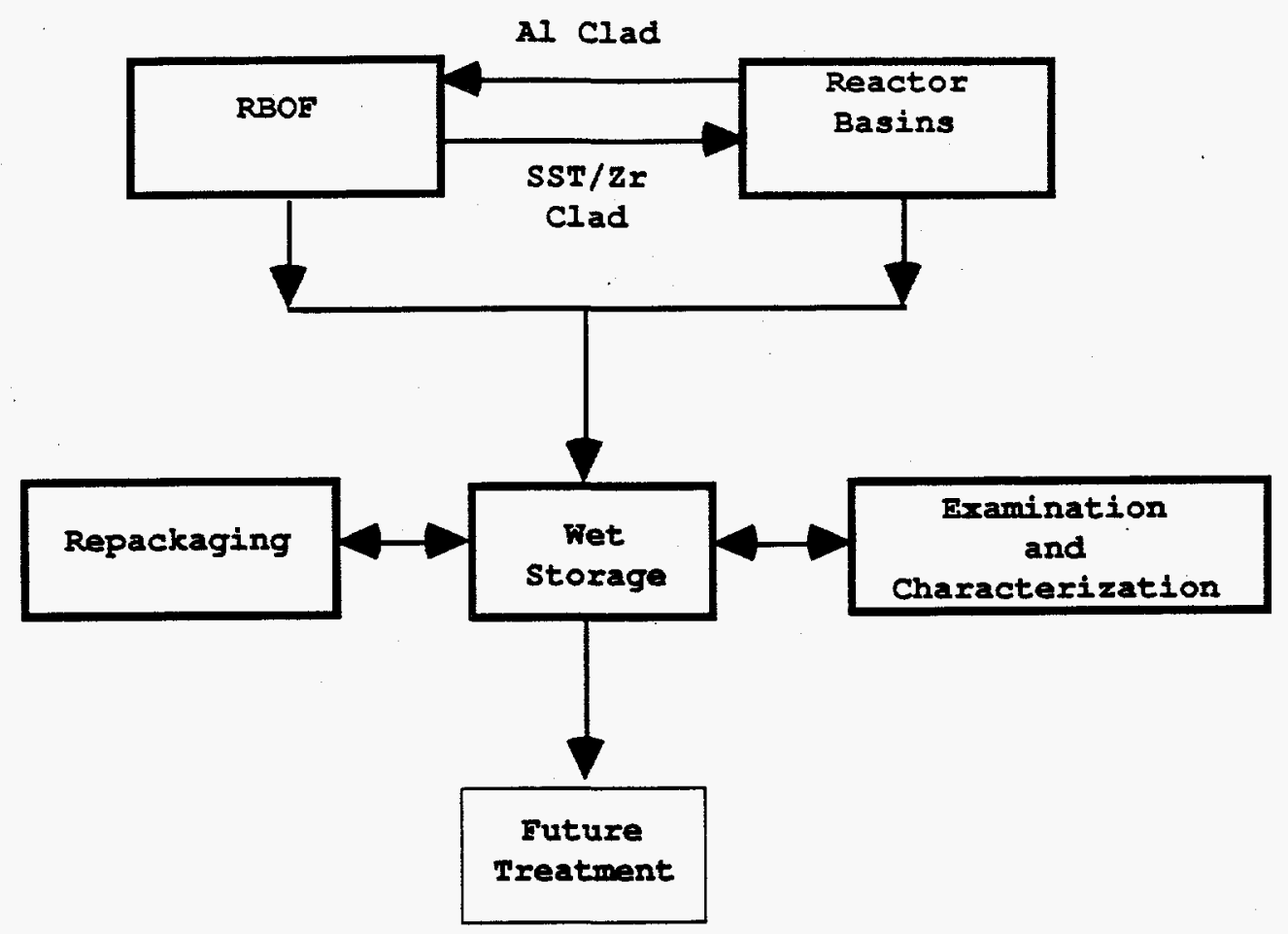


Section 4

Technical Data Summary supporting the INEL spent Fuel eIs

Document No. NMP-PLS-930182, Reviston 2

March 22, 1929

TABLE 5

PERSONNEL AND COST DATA FOR CASE 2b

\begin{tabular}{|c|c|c|c|c|c|}
\hline \multirow[t]{2}{*}{ YEAR } & \multicolumn{2}{|c|}{ PERSONNEL } & \multicolumn{2}{|c|}{$\begin{array}{c}\text { FONDING } \\
\text { (\$M1IIIOns) } \\
\end{array}$} & $\begin{array}{c}\text { OTILITY COSTS } \\
\text { (\$MIIIIONS) }\end{array}$ \\
\hline & CAPITAL & OPERATIONS & CAPITAI & OPERATIONS & \\
\hline 1994 & 100 & 4,960 & .10 .0 & 374.0 & 28.0 \\
\hline 1995 & 90 & 4.800 & 9.0 & 371.0 & 28.0 \\
\hline 1996 & 80 & 4,730 & 8.0 & 372.0 & 28.0 \\
\hline 1997 & 70 & 4,110 & 7.0 & 331.0 & 28.0 \\
\hline 1998 & 60 & 3,790 & 6.0 & 313.0 & 21.0 \\
\hline 1999 & 60 & 3,060 & 6.0 & 258.0 & 21.0 \\
\hline 2000 & 450 & 2,350 & 51.0 & 203.0 & 22.0 \\
\hline 2001 & 790 & 2,350 & 91.0 & 207.0 & 22.0 \\
\hline 2002 & 1,150 & 2,450 & 137.0 & 220.0 & 22.0 \\
\hline 2003 & 1,040 & 2.730 & 127.0 & 251.0 & 22.0 \\
\hline 2004 & 380 & 2,960 & 47.0 & 278.0 & 22.0 \\
\hline 2005 & 60 & 3.170 & 7.0 & 305.0 & 23.0 \\
\hline 2006 & 60 & 3,170 & 7.0 & 311.0 & 23.0 \\
\hline 2007 & 60 & 3,170 & 7.0 & 318.0 & 23.0 \\
\hline 2008 & 60 & 3,050 & 7.0 & 313.0 & 23.0 \\
\hline 2009 & 140 & 2,870 & 20.0 & 301.0 & 23.0 \\
\hline 2010 & 140 & 2,870 & 20.0 & 307.0 & 24.0 \\
\hline 2011 & 140 & 2,870 & 20.0 & 314.0 & 24.0 \\
\hline 2012 & 60 & 2.870 & 8.0 & 321.0 & 24.0 \\
\hline 2013 & 60 & 2,870 & 8.0 & 328.0 & 24.0 \\
\hline 2014 & 60 & 2,870 & 8.0 & 335.0 & 24.0 \\
\hline .2015 & 60 & 2,870 & 9.0 & 343.0 & 25.0 \\
\hline 2016 & 60 & 2,870 & 9.0 & 350.0 & 25.0 \\
\hline 2017 & 60 & 2,870 & 9.0 & 358.0 & 25.0 \\
\hline 2018 & 60 & 2.870 & 9.0 & 366.0 & 25.0 \\
\hline 2019 & 60 & 2,870 & 9.0 & 410.0 & 25.0 \\
\hline 2020 & 60 & 2,870 & 10.0 & 418.0 & 26.0 \\
\hline 2021 & 60 & 2,930 & 10.0 & 436.0 & 26.0 \\
\hline 2022 & 60 & 2.850 & 10.0 & 435.0 & 26.0 \\
\hline 2023 & 60 & 2,790 & 10.0 & 434.0 & 26.0 \\
\hline 2024 & 60 & 2,690 & 11.0 & 427.0 & 26.0 \\
\hline 2025 & 60 & 2,670 & 11.0 & 434.0 & 27.0 \\
\hline 2026 & 60 & 2,690 & 11.0 & 447.0 & 27.0 \\
\hline 2027 & 60 & 2,670 & 11.0 & 454.0 & 27.0 \\
\hline 2028 & 300 & 2,660 & 62.0 & 461.0 & 29.0 \\
\hline 2029 & 520 & 2,670 & 112.0 & 474.0 & 30.0 \\
\hline 2030 & 740 & 2,710 & 162.0 & 492.0 & 30.0 \\
\hline 2031 & 730 & 2,820 & 162.0 & 523.0 & 30.0 \\
\hline 2032 & 270 & 2,860 & 63.0 & 541.0 & 30.0 \\
\hline 2033 & 60 & 2,820 & 13.0 & 546.0 & 35.0 \\
\hline 2034 & 60 & 2,800 & 13.0 & 555.0 & 35.0 \\
\hline 2035 & 940 & 2,740 & 224.0 & 553.0 & 35.0 \\
\hline
\end{tabular}


Saction 4

Tachnlcal Data Summary supporting the Ival spent Fuel EIS

Document No. NMP-RIS-930182, Revision 2

Narch 22. 1924

TABIE 6

WASTE AND EMISSIONS DATA FOR CASE 2b

\begin{tabular}{|c|c|c|c|c|c|c|}
\hline YEAR & \multicolumn{5}{|c|}{ WASTE VOLOMES } & EMISSIONS \\
\hline & $\begin{array}{c}\text { CANISTER } \\
\text { (qty.) }\end{array}$ & $\begin{array}{c}\text { SALTCRETE } \\
\text { (cu yds) }\end{array}$ & $\begin{array}{c}L L \\
(c u \quad f t)\end{array}$ & $\begin{array}{c}\text { SANITARY } \\
\text { (kgal) }\end{array}$ & $\begin{array}{c}\text { TRO - } \\
\text { (cu yds) }\end{array}$ & \\
\hline 1994 & 0 & 0 & 45,000 & 60,720 & 57 & slight \\
\hline 1995 & 0 & 0 & 45,000 & 58,680 & 57 & slight \\
\hline 1996 & 5 & 1,500 & 59,000 & 57,720 & 60 & slight \\
\hline 1997 & 6 & 1,500 & 59,000 & 50,160 & 60 & slight \\
\hline 1998 & 0 & 0 & 45,000 & 46,200 & 57 & sight \\
\hline 1999 & 0 & 0 & 45,000 & 37,440 & 57 & slight \\
\hline 2000 & 0 & 0 & 20,000 & 33,600 & 57 & slight \\
\hline 2001 & 0 & 0 & 20,000 & 37,680 & 57 & slight \\
\hline 2002 & 0 & 0 & 20,000 & 43,200 & 57 & slight \\
\hline 2003 & 0 & 0 & 20,000 & 45,240 & 57 & slight \\
\hline 2004 & 0 & 0 & 20,000 & 40,080 & 57 & slight \\
\hline 2005 & 0 & 0 & 20,000 & 38,760 & 57 & slight \\
\hline 2006 & 0 & 0 & 20,000 & 38,760 & 57 & slight \\
\hline 2007 & 0 & 0 & 20,000 & 38,760 & 57 & slight \\
\hline 2008 & 0 & 0 & 20,000 & 37,320 & 57 & slight \\
\hline 2009 & 0 & 0 & 20,000 & 36,120 & 57 & slight \\
\hline 2010 & 0 & 0 & 20,000 & 36,120 & 57 & slight \\
\hline 2011 & 0 & 0 & 20,000 & 36,120 & 57 & slight \\
\hline 2012 & 0 & 0 & 20,000 & 35,160 & 57 & slight \\
\hline 2013 & 0 & 0 & 20,000 & 35,160 & 57 & slight \\
\hline 2014 & 0 & 0 & 20,000 & 35,160 & 57 & slight \\
\hline 2015 & 0 & 0 & 20,000 & 35,160 & 57 & slight \\
\hline 2016 & 0 & 0 & 20,000 & 35,160 & 57 & slight \\
\hline 2017 & 0 & 0 & 20,000 & 35,160 & 57 & slight \\
\hline 2018 & 0 & 0 & 20,000 & 35,160 & 57 & slight \\
\hline 2019 & 0 & 0 & 20,000 & 35,160 & 57 & slight \\
\hline 2020 & 0 & 0 & 20,000 & 35,160 & 57 & slight \\
\hline 2021 & 0 & 0 & 20,000 & 35,880 & 57 & slight \\
\hline 2022 & 0 & 0 & 20,000 & 34,920 & 57 & slight \\
\hline 2023 & 0 & 0 & 20,000 & 34,200 & 57 & slight \\
\hline 2024 & 0 & 0 & 20,000 & 33,000 & 57 & slight \\
\hline 2025 & 0 & 0 & 20,000 & 32,760 & 57 & slight \\
\hline 2026 & 0 & 0 & 20,000 & 33,000 & 57 & slight \\
\hline 2027 & 0 & 0 & 20,000 & 32,760 & 57 & slight \\
\hline 2028 & 0 & 0 & 20,000 & 35,520 & 57 & slight \\
\hline 2029 & 0 & 0 & 20,000 & 38,280 & 57 & slight \\
\hline 2030 & 24 & 6,500 & 114,000 & 41,400 & 57 & slight \\
\hline 2031 & 24 & 6,500 & 114,000 & 42,600 & 60 & slight \\
\hline 2032 & 24 & 6,500 & 114,000 & 37,560 & 60 & slight \\
\hline 2033 & 0 & 0 & 45,000 & 34,560 & 60 & slight \\
\hline 2034 & 0 & 0 & 45,000 & 34,320 & $57 \%$ & slight \\
\hline 2035 & 0 & 0 & 45,000 & 44,160 & 57 & slight \\
\hline
\end{tabular}




\section{ORTION 2 - DECENTRALIZATION}

Case 2c - Provides interim dry storage for the existing SRS spent fuel inventory. This case will develop the technology necessary to dry store the spent fuels for the storage period. Capabilities to monitor, examine, characterize, and package the spent fuels are included.

ACTIVITY DESCRIPTION:

SRS will rearrange the spent fuels as described in Case 1 to provide acceptable storage conditions to minimize failure of the aluminum clad spent fuels prior to placement in a dry storage facility. Placement in a dry storage repository requires an extensive R\&D program to determine the characterization, examination and monitoring parameters required to meet all the DOE and NRC dry storage regulations.

The sequence of events in this scenario is as follows:

FY-94 The DOE will initiate the EIS process required to support: (1) temporary storage of spent fuels in existing facilities; (2) interim storage in a new dry storage facilities; and(3) process the solution inventory and other materials as required for safety.

SRS will begin research efforts and preconceptual studies leading toward dry storage of the SRS spent fuel inventory.

FY-95 The DOE will complete the EIS process by issuing the ROD permitting the proposed activities.

FY-96 SRS will initiate a Congressional Line Item project to provide interim dry storage facilities.

SRS will initiate a program which will relocate all the aluminum clad spent fuels currently stored in the reactor basin to RBOF. This extensive program will renovate the selected reactor basin to improve water quality.

SRS will begin processing the solution inventories and other materials as required for safety. 
FY-97 At the completion of the program to renovate the reactor basin, SRS will relocate the SST/Zr clad spent fuels in the SRS inventory from RBOF to the selected reactor basin. As the SST/Zr clad spent fuels are transferred to the renovated reactor basin, these positions in RBOF will be backfilled with aluminum clad spent fuels from the other two reactor basins.

The CDR for the dry storage facilities project will be completed.

Processing the solutions and other materials will be completed. The flushing and cleanout activities will begin.

FY-98 All aluminum fuels will be consolidated in RBOF; all SST/Zr spent fuels will be stored in an renovated reactor basin.

The existing basins will be placed into a S\&M mode until the new facilities are ready for operations.

The chemical separation facilities will be placed into a $S \& M$ mode.

FY-99 The dry storage facilities project will be authorized.

FY-0O The design and construction activities will begin.

FY-02 Preparation for the startup activities will commence.

FY-04 Construction will be completed.

Startup activities will begin.

FY-06 After all readiness reviews are satisfactorily completed, the facilities will begin operations.

FY-10 AlI the SNF will be transferred into the dry storage facilities. All the dry storage facilities will be placed into an S\&M mode which includes regular examination, analysis and monitoring of the SNE. The existing basins will be placed into a S\&M mode.

FY-21 SRS will initiate the research and development (R\&D) program necessary to obtain the final disposal of the SRS inventory of spent fuels. 
FY-24 Based on the R\&D program recommendations, SRS will initiate a Congressional Line Item project to design, construct, and operate the final disposition treatment facility.

FY-25 The CDR for this project will be completed.

FY-27 Congress will authorize the project.

EY-28 Design and construction activities will begin.

FY-30 Preparation for the startup activities will commence.

FY-32 Construction will be completed.

Startup activities will begin.

FY-33 After all the readiness reviews are satisfactorily completed, the facility will start operations.

FY-34 Processing the spent fuels into the final disposition form will be completed. The flushing and cleanout activities will commence.

FY-35 The facility will be placed into the S\&M mode.

FACILITIES USED IN THIS CASE:

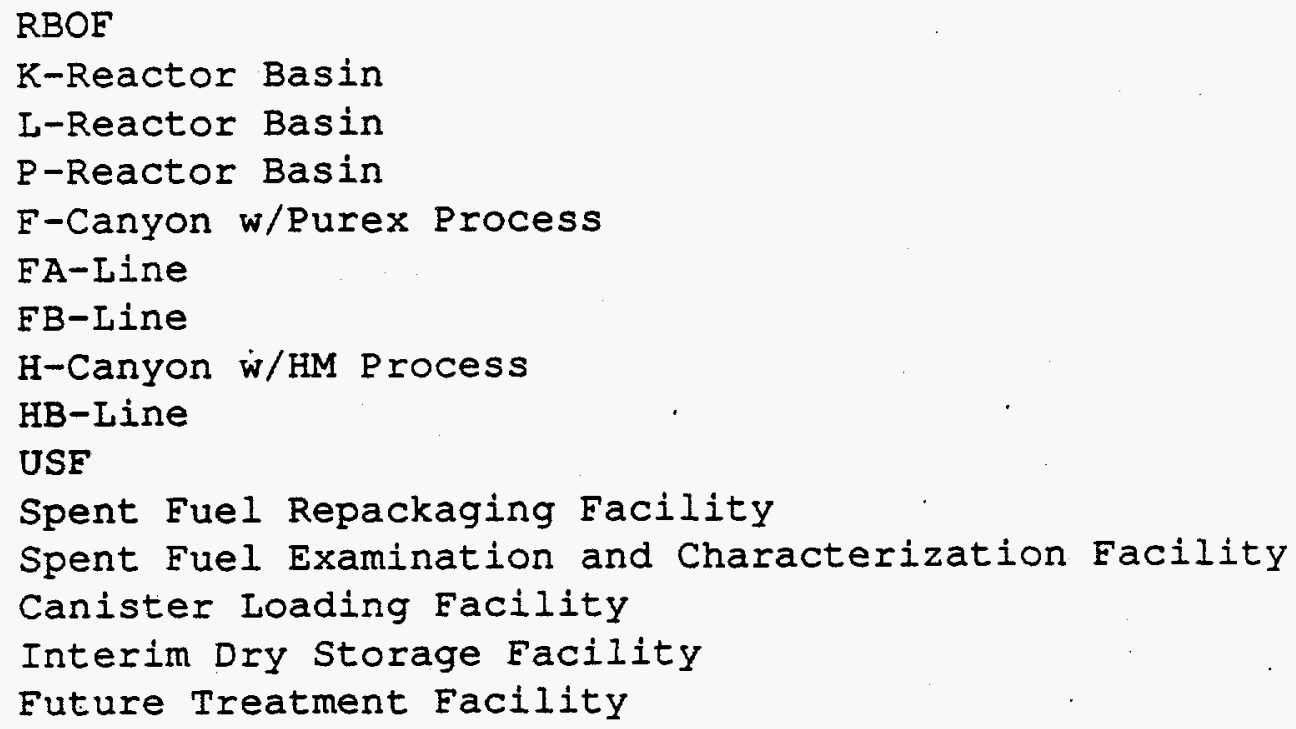


Section

Technical Data Summary Supporting the INEL Spent Fuel EIS

Document No. NMP-PIS-930182, Revision 2

March $22, \quad 1924$

\section{OPEN ISSUES:}

Acceptable resolution of the EIS process permitting the interim storage of the existing SRS spent fuel inventory and the processing of the solutions.

Dry storage of HEU aluminum clad spent fuels for an extended period is an unproven technology. Although commercial dry storage technology has been in use for some time, there are key parameters which will require development before HEU aluminum clad spent fuels can be stored in this manner (e.g., inspection capability, criticality control, radiation exposure).

Dry storage of the spent fuels is only an interim action. No disposition technology exists except future treatment. The encapsulation of the spent fuels required by the dry storage technology makes future treatment options more difficult and expensive.

Large capital expenditures are required to design, construct, operate, then $D \& D$ the new facilities.

Large annular budgets are required to operate the facilities. 
Technical Data Summary supporting the INEL Spent Fuel EIS

Document No. NMP-PIS-930182, Revision 2

varch 22. 1994

\section{FIGURE 5}

ELOW CHART FOR CASE $2 \mathrm{C}$

Al Clad

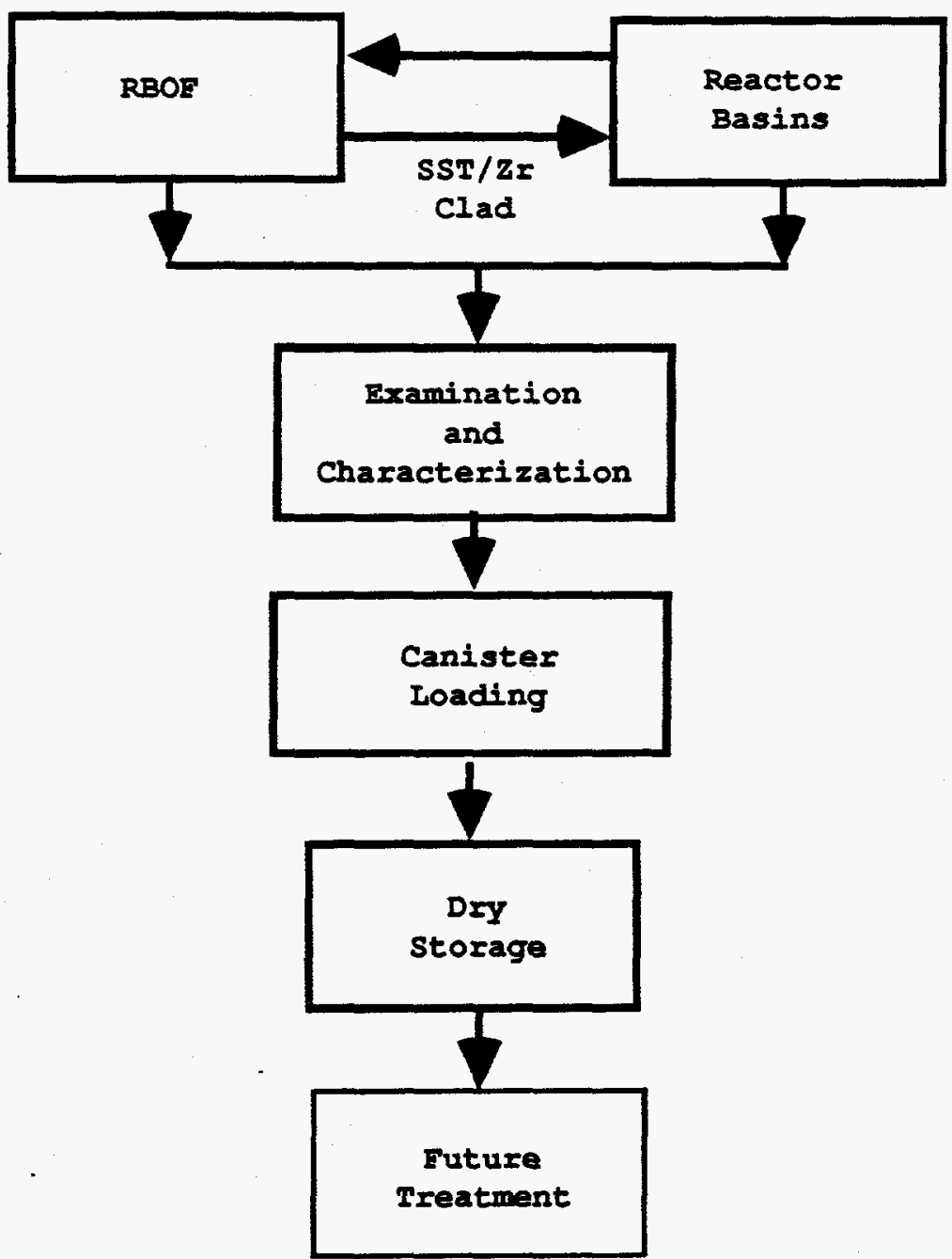


Section 4

Technical Data Summary Supporting the INal spent Fuel IIS

Document No. MMP-PLS-930182, Revision 2

March 22, 1994

TABLE 7

PERSONNEL AND COST DATA FOR CASE 2C

\begin{tabular}{|c|c|c|c|c|c|}
\hline YEAR & \multicolumn{2}{|c|}{ PERSONNEI } & \multicolumn{2}{|c|}{$\begin{array}{c}\text { FONDING } \\
\text { (\$Millions) }\end{array}$} & $\begin{array}{l}\text { OTILITY COST } \\
\text { (SMIIIIOns) }\end{array}$ \\
\hline & CAPITAL & ORERATIONS & CAPITAI & OPERATIONS & \\
\hline 1994 & 100 & 4,960 & 10.0 & 374.0 & 28.0 \\
\hline 1995 & 90 & 4,800 & 9.0 & 371.0 & 28.0 \\
\hline 1996 & 80 & 4,730 & 8.0 & 372.0 & 28.0 \\
\hline 1997 & 70 & 4,110 & 7.0 & 331.0 & 28.0 \\
\hline 1998 & 60 & 3,790 & 6.0 & 313.0 & 21.0 \\
\hline 1999 & 60 & 3,060 & 6.0 & 258.0 & 21.0 \\
\hline 2000 & 450 & 2,350 & 51.0 & 203.0 & 22.0 \\
\hline 2001 & 790 & 2,350 & 91.0 & 207.0 & 22.0 \\
\hline 2002 & 1,150 & 2,450 & 137.0 & 220.0 & 22.0 \\
\hline 2003 & 1,040 & 2,720 & 127.0 & 251.0 & 22.0 \\
\hline 2004 & 380 & 2,960 & 47.0 & 278.0 & 22.0 \\
\hline 2005 & 60 & 3,170 & 7.0 & 305.0 & 23.0 \\
\hline 2006 & 60 & 3,170 & 7.0 & 311.0 & 23.0 \\
\hline 2007 & 60 & 3,170 & 7.0 & 318.0 & 23.0 \\
\hline 2008 & 60 & 3,050 & 7.0 & 313.0 & 23.0 \\
\hline 2009 & 140 & 2,870 & 20.0 & 301.0 & 23.0 \\
\hline 2010 & 140 & 2,870 & 20.0 & 307.0 & 24.0 \\
\hline 2011 & 140 & 2,870 & 20.0 & 314.0 & 24.0 \\
\hline 2012 & 60 & 2,870 & 8.0 & 321.0 & 24.0 \\
\hline 2013 & 60 & 2,870 & 8.0 & 328.0 & 24.0 \\
\hline 2014 & 60 & 2,870 & 8.0 & 335.0 & 24.0 \\
\hline 2015 & 60 & 2,870 & 9.0 & 343.0 & 25.0 \\
\hline 2016 & 60 & 2,870 & 9.0 & 350.0 & 25.0 \\
\hline 2017 & 60 & 2,870 & 9.0 & 358.0 & 25.0 \\
\hline 2018 & 60 & 2,870 & 9.0 & 366.0 & 25.0 \\
\hline 2019 & 60 & 2,870 & 9.0 & 410.0 & 25.0 \\
\hline 2020 & 60 & 2,870 & 10.0 & 418.0 & 26.0 \\
\hline 2021 & 60 & 2,920 & 10.0 & 436.0 & 26.0 \\
\hline 2022 & 60 & 2,850 & 10.0 & 435.0 & 26.0 \\
\hline 2023 & 60 & 2,790 & 10.0 & 434.0 & 26.0 \\
\hline 2024 & 60 & 2,690 & 11.0 & 427.0 & 26.0 \\
\hline 2025 & 60 & 2,670 & 11.0 & 434.0 & 27.0 \\
\hline 2026 & 60 & 2,690 & 11.0 & 447.0 & 27.0 \\
\hline 2027 & 60 & 2,670 & 11.0 & 454.0 & 27.0 \\
\hline 2028 & 300 & 2,660 & 62.0 & 461.0 & 29.0 \\
\hline 2029 & 520 & 2,670 & 112.0 & 474.0 & 30.0 \\
\hline 2030 & 740 & 2,710 & 162.0 & 492.0 & 30.0 \\
\hline 2031 & 730 & 2,820 & 162.0 & 523.0 & 30.0 \\
\hline 2032 & 270 & 2,860 & 63.0 & 541.0 & 30.0 \\
\hline 2033 & 60 & 2,820 & 13.0 & 546.0 & 35.0 \\
\hline 2034 & 60 & 2,800 & 13.0 & 555.0 & 35.0 \\
\hline 2035 & 940 & 2,740 & 224.0 & 553.0 & 35.0 \\
\hline
\end{tabular}


Section 4

Technical Data Sumary Supporting the INEI spent Fuel EIS

Document No. NMP-PLS-930182, Revision 2

March 22. 2994

TABLE 8

WASTE AND EMISSIONS DATA FOR CASE 2C

\begin{tabular}{|c|c|c|c|c|c|c|}
\hline YEAR & \multicolumn{5}{|c|}{ WASTE VOLUMES } & EMISSIONS \\
\hline & $\begin{array}{c}\text { CANISTER } \\
(\text { aty.) }\end{array}$ & $\begin{array}{c}\text { SAITCRETE } \\
\text { (cu yds) }\end{array}$ & $\begin{array}{c}\mathbf{L} \mathbf{L} \\
(\mathrm{cu} f t)\end{array}$ & $\begin{array}{c}\text { SANITARY } \\
\text { (Kgal) }\end{array}$ & $\begin{array}{c}\text { TRO. } \\
\text { (cu yds) }\end{array}$ & \\
\hline 1994 & 0 & 0 & 45,000 & $60,720^{\circ}$ & 57 & Slight \\
\hline 1995 & 0 & 0 & 45,000 & 58,680 & 57 & slight \\
\hline 1996 & 5 & 1,500 & 59,000 & 57,720 & 60 & Slight \\
\hline 1997 & 6 & 1,500 & 59,000 & 50,160 & 60 & Slight \\
\hline 1998 & 0 & 0 & 45,000 & 46,200 & 57 & Slight \\
\hline 1999 & 0 & 0 & 45,000 & 37,440 & 57 & Slight \\
\hline 2000 & 0 & 0 & 20,000 & 33,600 & 57 & Slight \\
\hline 2001 & 0 & 0 & 20,000 & 37,680 & 57 & Slight \\
\hline 2002 & 0 & 0 & 20,000 & 43,200 & 57 & Slight \\
\hline 2003 & 0 & 0 & 20,000 & 45,120 & 57 & Slight \\
\hline 2004 & 0 & 0 & 20,000 & 40,080 & 57 & Slight \\
\hline 2005 & 0 & 0 & 20,000 & 38,760 & 57 & Slight \\
\hline 2006 & 0 & 0 & 20,000 & 38,760 & 57 & Slight \\
\hline 2007 & 0 & 0 & 20,000 & 38,760 & 57 & Slight \\
\hline 2008 & 0 & 0 & 20,000 & 37,320 & 57 & Slight \\
\hline 2009 & 0 & 0 & 20,000 & 36,120 & 57 & Slight \\
\hline 2010 & 0 & 0 & 20,000 & 36,120 & 57 & slight \\
\hline 2011 & 0 & 0 & 20,000 & 36,120 & 57 & pight \\
\hline 2012 & 0 & 0 & 20,000 & 35,160 & 57 & Slight \\
\hline 2013 & 0 & 0 & 20,000 & 35,160 & 57 & Slight \\
\hline 2014 & 0 & 0 & 20,000 & 35,160 & 57 & Slight \\
\hline 2015 & 0 & 0 & 20,000 & 35,160 & 57 & Slight \\
\hline 2016 & 0 & 0 & 20,000 & 35,160 & 57 & sfight \\
\hline 2017 & 0 & 0 & 20,000 & 35,160 & 57 & Sllight \\
\hline 2018 & 0 & 0 & 20,000 & 35,160 & 57 & sllight \\
\hline 2019 & 0 & 0 & 20,000 & 35,160 & 57 & sllght \\
\hline 2020 & 0 & 0 & 20,000 & 35,160 & 57 & slight \\
\hline 2021 & 0 & 0 & 20,000 & 35,760 & 57 & Slight \\
\hline 2022 & 0 & 0 & 20,000 & 34,920 & 57 & Slight \\
\hline 2023 & 0 & 0 & 20,000 & 34,200 & 57 & Slilght \\
\hline 2024 & 0 & 0 & 20,000 & 33,000 & 57 & S1 foht \\
\hline 2025 & 0 & 0 & 20,000 & 32,760 & 57 & Slifght \\
\hline 2026 & 0 & 0 & 20,000 & 33,000 & 57 & Slight \\
\hline 2027 & 0 & 0 & 20,000 & 32,760 & 57 & slight \\
\hline 2028 & 0 & 0 & 20,000 & 35,520 & 57 & Elight \\
\hline 2029 & 0 & 0 & 20,000 & 38,280 & 57 & Slight \\
\hline 2030 & 0 & 0 & 20,000 & 41,400 & 57 & Slight \\
\hline 2031 & 0 & 0 & 20,000 & 42,600 & 60 & slight \\
\hline 2032 & 0 & 0 & 20,000 & 37,560 & 60 & Slight \\
\hline 2033 & 24 & 6,500 & 114,000 & 34,560 & 60 & Slight \\
\hline 2034 & 24 & 6,500 & 114,000 & 34,320 & 57 & Slight \\
\hline 2035 & 24 & 6,500 & 114,000 & 44,160 & 57 & Slight \\
\hline
\end{tabular}




\section{OPTION 3 - RIANNING BASIS}

SRS will manage its existing spent fuel inventory and the planned offsite receipts. Alternative wet and dry storage as well as processing options are considered. The rearrangement of the sRs spent fuel inventory will be performed as part of the two storage cases.

SPENT FUEL INVENTORY DESCRIPTION:

Current Inventories

Type 2 SRS reactor spent fuels (HEU/Al clad) including the Pu targets (DU/Al clad) - $183.6 \mathrm{MTHM}$

Type 6a Research reactor SST clad (HEU/LEU) - 11.3 MTHM

Type 6b Research reactor $\mathrm{Zr}$ clad (HEU/LEU) - 11.8 MTHM

Planned Receipts

Type 2 Aluminum clad research reactor fuels from university and foreign sites (HEU/LEU) - 11.9 MTHM 
Section 4

Technlcal Data Sumary Supporting the INEL spent Fuel EIS

Document No. NMP-PLS-930182, Revision 2

Warch $22, \quad 1924$

Case $3 a$ - SRS will process the SRS aluminum clad spent fuel inventory and the $P u$ targets to stabilize the SNM for vault storage. The special clad spent fuels in the existing sRs inventory will placed into new dry storage facilities along with all the planned receipts.

ACTIVITY DESCRIPTION:

SRS will process the existing SRS aluminum clad inventories to safe, stable, and consolidated forms for storage in a product vault.

The Pu targets will be processed in the F-Area facilities using the PUREX Process. The Pu bearing solution will be processed to metal in FB-Iine; while the DU bearing one will be converted to an oxide in the FA-Line facility.

The spent fuels will be processed in the H-Canyon using the HM Process. The resulting HEU solutions will be converted to an oxide in the USF.

A Congressional Line Item project will be developed to provide dry storage facilities for the special clad and RR spent fuels.

The activities required for this case are as follows:

E-Area

FY-94 DOE will initiate the EIS process permitting the processing of the $\mathrm{Pu}$ targets.

EY-95 The DOE will complete the EIS process by issuing the ROD permitting the proposed activities.

FY-96 SRS will start processing the Pu targets and solutions.
H-Area

DOE will initiate the EIS process permitting the processing of the spent fuels.

The DOE will complete the EIS process by issuing the ROD permitting the proposed activities.

SRS will start processing the aluminum clad spent fuel inventory. 
E-Area

$E Y-96$

FY-97 Processing the Pu targets will be completed. The flushing and cleanout activities will begin.

FY-98 F-Area facilities will be placed into the $S \& M$ mode.

$F Y-99$ FY-00 The design and construction activities for the dry storage
facilities will begin.

FY-01 USE will complete its mission. USF will start flushing and cleanout activities.

FY-02 Preparation for the startup activities for the dry storage facilities will begin.

H-Area facilities will be placed into the S\&M mode.

FY-04 The construction of the dry storage facilities will be completed. Startup activities will begin.

Shipments of the $R R$ fuels can resume. 
Technical Data Summary Supporting the INEL spent Fuel EIS

Document No. NMP-PLS-930182, Revision 2

March $22 \quad 1294$

EY-06. After all the readiness reviews are completed, the dry storage facilities will begin operations.

FY-07 All the RR spent fuels will be received at SRS

EY-10 Transfer of the special clad spent fuels to dry storage have been completed. The basins and dry storage facilities will be in the S\&M mode. For the dry storage facilities, this includes some examination, analysis, and monitoring activities.

FY-21 SRS will initiate the R\&D program necessary to develop the final disposition of the SRS spent fuel inventory.

FY-23 Based on the R\&D program recommendations, SRS will initiate a Congressional Line Item project to design, construct, and operate the final disposition treatment facility.

FY-24 The CDR for the treatment facility project will be completed.

FY-27 Congress will authorize the project.

FY-28 The design and construction activities will begin.

FY-27 Preparation for the startup activities will commence.

FY-29 Construction will be completed. Startup activities will begin.

FY-33 After all the readiness reviews are satisfactorily completed, the facility will start operations.

FY-34 Processing the spent fuels into the final disposition form will be completed. The flushing and cleanout activities will begin..

FY-35 The treatment facility will be placed into the S\&M mode or made available for other programs. 
Technical Data sumary Supporting the INEI spent Fuel EIS

Document No. NMP-PLS-930182, Revision 2

March 22, 2924

FACILITIES USED IN THIS CASE:

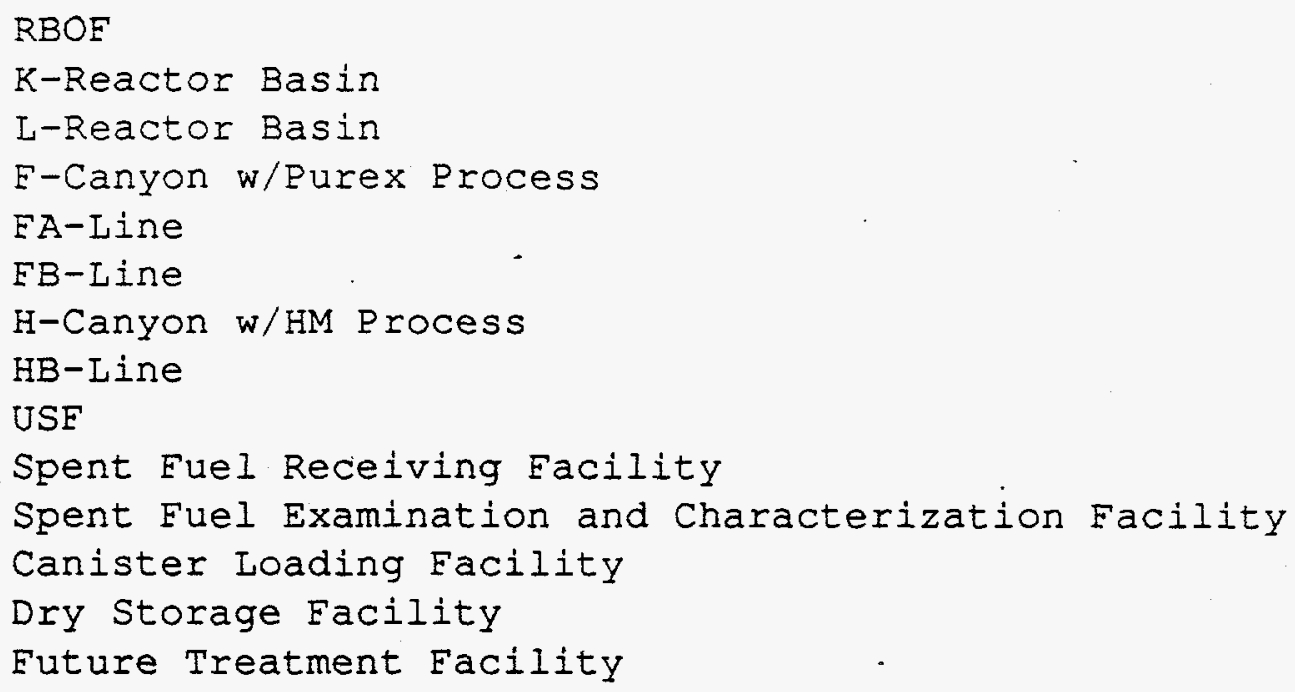

OPEN ISSUES :

Acceptable resolution of the EIS process permitting the reprocessing operations in SRS chemical separations facilities plus the interim dry storage of spent fuels.

Large capital expenditures are required to design, construct operate, then D\&D the new facilities.

Large annual budgets are required to operate the facilities. 
Section 4

Technical Data Sumary supporting the rNal spent ruel EIS

Document No. NMP-PLS-930182, Revision 2

March 22, 1924

\section{EIGURE 6}

ELOW CHART EOR CASE 3 a

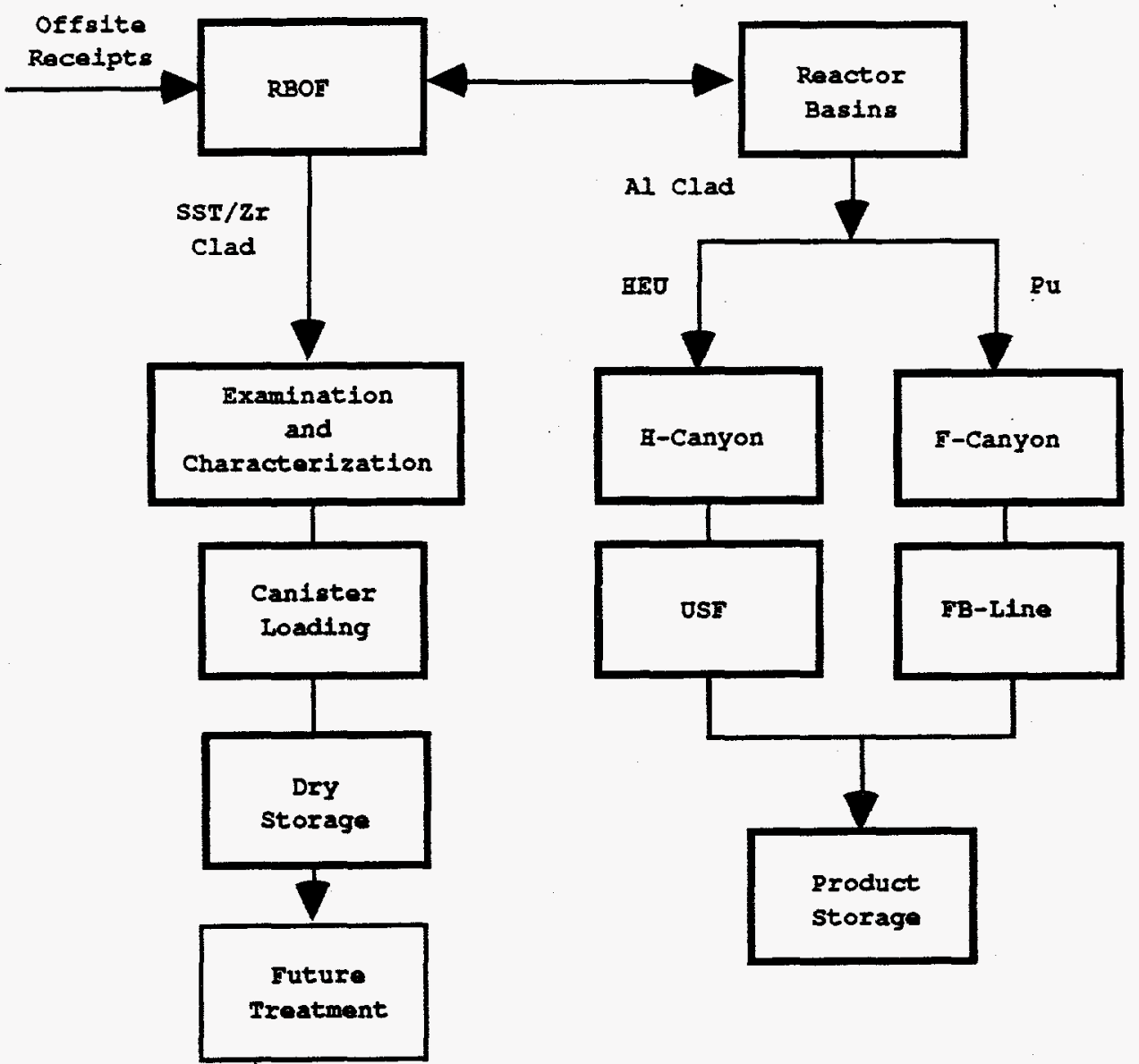


Section 4

Technical Data sumary supporting the INEL Spent Fuel EIS

Document No. MMP-PLS-930182, Revision 2

March 22, 1924

TABLE 9

PERSONNEL AND COST DATA FOR CASE 3 a

\begin{tabular}{|c|c|c|c|c|c|}
\hline \multirow[t]{2}{*}{ YEAR } & \multicolumn{2}{|c|}{ RERSONNEI } & \multicolumn{2}{|c|}{$\begin{array}{c}\text { FUNDING } \\
\text { (\$MIIIIOns) }\end{array}$} & \multirow[t]{2}{*}{$\begin{array}{c}\text { OTILITY COST } \\
\text { (SMIIIIOns) }\end{array}$} \\
\hline & CAPITAL & OPERATIONS & CAPITAL & OPERATIONS & \\
\hline 1994 & 100 & 4,960 & .10 .0 & 374.0 & 28.0 \\
\hline 1995 & 90 & 4,870 & 9.0 & 374.0 & 28.0 \\
\hline 1996 & 80 & 4,800 & 8.0 & 378.0 & 28.0 \\
\hline 1997 & 70 & 4,170 & 7.0 & 336.0 & 28.0 \\
\hline 1998 & 60 & 3,860 & 6.0 & 319.0 & 21.0 \\
\hline 1999 & 60 & 3,410 & 6.0 & 290.0 & 21.0 \\
\hline 2000 & 360 & 3,180 & 41.0 & 278.0 & 22.0 \\
\hline 2001 & 700 & 3,190 & 81.0 & 284.0 & 22.0 \\
\hline 2002 & 1,060 & 3,210 & 127.0 & 293.0 & 22.0 \\
\hline 2003 & 960 & 3,490 & 117.0 & 324.0 & 22.0 \\
\hline 2004 & 300 & 3,720 & 37.0 & 353.0 & 22.0 \\
\hline 2005 & 60 & 3,950 & 7.0 & 383.0 & 23.0 \\
\hline 2006 & 60 & 3,860 & 7.0 & 381.0 & 23.0 \\
\hline 2007 & 60 & 3,490 & 7.0 & 350.0 & 23.0 \\
\hline 2008 & 60 & 3,100 & 7.0 & 318.0 & 23.0 \\
\hline 2009 & 60 & 3,010 & 8.0 & 316.0 & 19.0 \\
\hline 2010 & 140 & 2,850 & 20.0 & 306.0 & 19.0 \\
\hline 2011 & 140 & 2,850 & 20.0 & 313.0 & 19.0 \\
\hline 2012 & 140 & 3,850 & 20.0 & 61.2 & 19.0 \\
\hline 2013 & 60 & 2,850 & 8.0 & 327.0 & 20.0 \\
\hline 2014 & 60 & 2,850 & 8.0 & 334.0 & 20.0 \\
\hline 2015 & 60 & 2,850 & 9.0 & 341.0 & 20.0 \\
\hline 2016 & 60 & 2,850 & 9.0 & 349.0 & 20.0 \\
\hline 2017 & 60 & 2.850 & 9.0 & 356.0 & 21.0 \\
\hline 2018 & 60 & 2,850 & 9.0 & 364.0 & 21.0 \\
\hline 2019 & 60 & 2,850 & 9.0 & 410.0 & 21.0 \\
\hline 2020 & 60 & 2,850 & 10.0 & 418.0 & 21.0 \\
\hline 2021 & 60 & 2,910 & 10.0 & 436.0 & 22.0 \\
\hline 2022 & 60 & 2,840 & 10.0 & 435.0 & 22.0 \\
\hline 2023 & 60 & 2.780 & 10.0 & 434.0 & 22.0 \\
\hline 2024 & 60 & 2,670 & 11.0 & 427.0 & 22.0 \\
\hline 2025 & 60 & 2,660 & 10.0 & 434.0 & 23.0 \\
\hline 2026 & 60 & 2,670 & 11.0 & 447.0 & 23.0 \\
\hline 2027 & 60 & 2,660 & 11.0 & 454.0 & 23.0 \\
\hline 2028 & 300 & 2,650 & 62.0 & 461.0 & 23.0 \\
\hline 2029 & 520 & 2,660 & 112.0 & 474.0 & 24.0 \\
\hline 2030 & 740 & 2,700 & 162.0 & 492.0 & 24.0 \\
\hline 2031 & 730 & 2,810 & 162.0 & 523.0 & 24.0 \\
\hline 2032 & 270 & 2,840 & 63.0 & 541.0 & 28.0 \\
\hline 2033 & 60 & 2.810 & 13.0 & 546.0 & 35.0 \\
\hline 2034 & 60 & 2,790 & 13.0 & 555.0 & 35.0 \\
\hline 2035 & 870 & 2.720 & 208.0 & 2,720 & 35.0 \\
\hline
\end{tabular}


Section 4

Technical Data sumary supporting the INEL spent Fuel EIS

Document No. NMP-PIS-930182, Revision 2

March 22, 1294

TABLE 10

WASTE AND EMISSIONS DATA FOR CASE 3a

\begin{tabular}{|c|c|c|c|c|c|c|}
\hline YEAR & \multicolumn{5}{|c|}{ NASTE VOLDMES } & EMISSIONS \\
\hline & $\begin{array}{c}\text { CANISTER } \\
\text { (Gty.) }\end{array}$ & $\begin{array}{c}\text { SALTCRETE } \\
\text { (cu yds) }\end{array}$ & $\begin{array}{c}I L \\
(c u f t)\end{array}$ & $\begin{array}{c}\text { SANITARY } \\
\text { (Kgal) }\end{array}$ & $\begin{array}{c}\text { TRO } \\
\text { (cu yds) }\end{array}$ & \\
\hline 1994 & 0 & 0 & 45,000 & 60,720 & 57 & Slight \\
\hline 1995 & 0 & 0 & 45,000 & 59,520 & 57 & Slight \\
\hline 1996 & 16 & 4839 & 91,000 & 58,560 & 65 & Slight \\
\hline 1997 & 17 & 4839 & 91,000 & 50,880 & 65 & Slight \\
\hline 1998 & 17 & 4839 & 91,000 & 47,040 & 65 & Slight \\
\hline 1999 & -17 & $\theta 4839$ & 45,000 & 41,640 & 57 & Slight \\
\hline 2000 & 0 & 0 & 20,000 & 42,480 & 20 & Slight \\
\hline 2001 & 0 & 0 & 20,000 & 46,680 & 20 & Slight \\
\hline 2002 & 0 & 0 & 20,000 & 51,240 & 20 & Slight \\
\hline 2003 & 0 & 0 & 20,000 & 53,400 & 20 & Slight \\
\hline 2004 & 0 & 0 & 20,000 & 48,240 & 20 & Slight - \\
\hline 2005 & 0 & 0 & 20,000 & 48,120 & 20 & Slight \\
\hline 2006 & 0 & 0 & 20,000 & 47,040 & 20 & Slight \\
\hline 2007 & 0 & $\overline{0}$ & 20,000 & 42,600 & 20 & Slight \\
\hline 2008 & 0 & 0 & 20,000 & 37,920 & 20 & Slight \\
\hline 2009 & 0 & 0 & 20,000 & 36,840 & 20 & Slight \\
\hline 2010 & 0 & 0 & 20,000 & 35,880 & 20 & Slight \\
\hline 2011 & 0 & 0 & 20,000 & 35,880 & 20 & Slight \\
\hline 2012 & 0 & 0 & 20,000 & 47,880 & 20 & Slight \\
\hline 2013 & 0 & 0 & 20,000 & 34,920 & 20 & Slight \\
\hline 2014 & 0 & 0 & 20,000 & 34,920 & 20 & Slight \\
\hline 2015 & 0 & 0 & 20,000 & 34,920 & 20 & Slight \\
\hline 2016 & 0 & 0 & 20,000 & 34,920 & 20 & Slight \\
\hline 2017 & 0 & 0 & 20,000 & 34,920 & 20 & Slight \\
\hline 2018 & 0 & 0 & 20,000 & 34,920 & 20 & Slight \\
\hline 2019 & 0 & 0 & 20,000 & 34,920 & 20 & Slight \\
\hline 2020 & 0 & 0 & 20,000 & 34,920 & 20 & Slight \\
\hline 2021 & 0 & 0 & 20,000 & 35,640 & 20 & slight \\
\hline 2022 & 0 & 0 & 20,000 & 34,800 & 20 & Slight \\
\hline 2023 & 0 & 0 & 20,000 & 34,080 & 20 & Slight \\
\hline 2024 & 0 & 0 & 20,000 & 32,760 & 20 & slight \\
\hline 2025 & 0 & 0 & 20,000 & 32,640 & 20 & Slight \\
\hline 2026 & 0 & 0 & 20,000 & 32,760 & 20 & Slight \\
\hline 2027 & 0 & 0 & 20,000 & 32,640 & 20 & Slight \\
\hline 2028 & 0 & 0 & 20,000 & 35.400 & 20 & Slight \\
\hline 2029 & 0 & 0 & 20,000 & 38,160 & 20 & Slight \\
\hline 2030 & 0 & 0 & 20,000 & 41,280 & 20 & Slight \\
\hline 2031 & 0 & 0 & 20,000 & 42,480 & 20 & Slight \\
\hline 2032 & 0 & 0 & 20,000 & 37,320 & 40 & Slight \\
\hline 2033 & 7 & 900 & 65,000 & 34,440 & 45 & Slight \\
\hline 2034 & 8 & 900 & 65,000 & 34,200 & 57 & Slight \\
\hline 2035 & 0 & 0 & 20,000 & 43,080 & 20 & Slight \\
\hline
\end{tabular}




\section{OPTION 3 - PLANNING BASIS}
Case $3 b$ - Provides for the interim wet storage of the existing SRS spent fuel inventory plus the planned receipts of research reactor spent fuels. Additional capabilities to examine, analyze, characterize, and repackage the spent fuels is provided.

ACTIVITY DESCRIPTION:

The existing SRS spent fuel inventory is rearranged as in Case 1 to provide interim wet storage capability while new, complying facilities are constructed. The new wet storage facilities will meet all DOE and NRC requirements for SNF and SNM storage.

Included in these new storage facilities are the capabilities to monitor, examine, and characterize the spent fuels. All the spent fuels will be encapsulated in a stainless steel canister prior to placement in the pool.

Receipt of the RR spent fuels is delayed until the SRS spent fuels are relocated in the new wet storage facility.

The separations facilities will process the solution inventories and other materials as required for safety.

FY-94 The DOE will initiate the EIS process to support: (1) temporary storage of spent fuels in a reactor basin(s) and RBOF; (2) interim storage in new wet storage facilities; and (3) processing the solution inventory.

FY-95 The DOE will complete the EIS process by issuing the ROD permitting the proposed activities.

FY-96 SRS will embark on an extensive program to relocate the aluminum-clad spent fuels to RBOE and the special clad spent fuels to an improved reactor basin.

SRS will initiate a Congressional Iine Item project to construct new, fully complying wet storage facilities.

SRS can begin a limited receipt of $R R$ spent fuels.

SRS will begin processing the solution inventory along with any other materials as required for safety. 
FY-97 The CDR for the new wet storage facilities project will be completed.

Processing the solution inventory and other materials will be completed. The flushing and cleanout activities will begin.

FY-98 The relocation program will be completed.

The separation facilities will be placed into a S\&M mode.

EY-99 Congress will authorize the new wet storage facilities project.

FY-00 The design and construction activities will begin.

FY-02 Preparations for the startup activities can begin.

FY-04 Construction of the new wet storage facilities will be completed. The startup activities can begin.

FY-06 After all the readiness reviews are satisfactorily completed the new wet storage facilities can begin operations.

Shipments of the RR spent fuels to SRS can resume.

FY-10 Receipt of RR spent fuels will be complete.

FY-12 All the spent fuels will be placed into wet storage. The facilities will be placed into S\&M mode which will include some examination, analysis, and repackaging activities.

FY-18 SRS will initiate the R\&D program necessary to develop the final disposition of the SRS spent fuel inventory.

FY-20 Based on the R\&D program recommendations, SRS will initiate a Congressional Iine Item project to design, construct, and operate the final disposition treatment facility.

EY-22 The CDR for this project will be completed.

FY-24 Congress will authorize the project. 
EY-26 Design and construction activities will begin.

EY-28 Preparation for the startup activities will commence.

EY-30 Construction will be completed.

Startup activities will begin.

FY-32 After all the readiness reviews are satisfactorily completed, the facility will start operations.

FY-34 Processing the spent fuels into the final disposition form will be completed.

FY-35 The facility will be placed into a S\&M mode.

FACILITIES USED IN THIS CASE:

RBOF

K-Reactor Basin

I-Reactor Basin

P-Reactor Basin

Spent Fuel Receiving Facility

Spent Fuel Examination and Characterization Facility

Repackaging Facility

Interim Wet Storage Facility

Future Treatment Eacility

\section{OPEN ISSUES :}

Acceptable resolution of the EIS process which will permit the interim storage of spent fuels and the processing of the solutions.

Wet storage of spent fuels is an interim action. No disposition technology exists except some type of future processing. The encapsulation necessary to contain aluminum clad spent fuels through interim wet storage period makes future processing more complex and costly.

Return of RR spent fuels, including HEU fuels, will be delayed.

Large capital expenditures for the design, construction, then D\&D of the new facilities are required.

Large annual budgets are required to operate the facilities. 
Section 4

Technical Data Summary Supporting the INEI Spent Fuel EIS

Document No. NMP-PLS-930182, Revision

March $22, \quad 1924$

\section{FIGURE 7}

FIOW CHART FOR CASE $3 \mathrm{~b}$

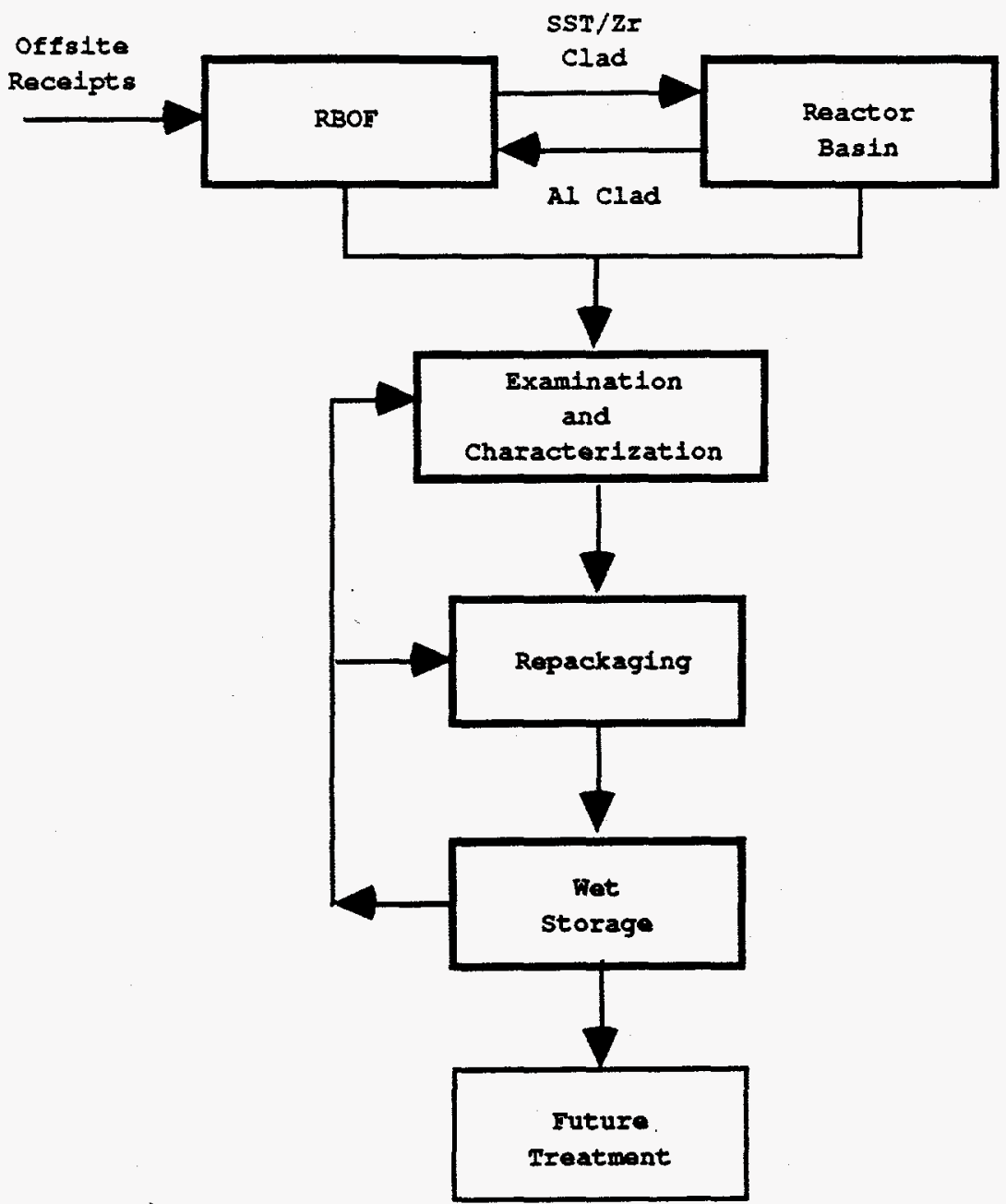


Section 4

Technical Data Summary supporting the INEL spent Fuel EIS

Document No. NMP-PLS-930182, Revision 2

March 22_ 1994

TABLE 11

PERSONNEL AND COST DATA FOR CASE 3b

\begin{tabular}{|c|c|c|c|c|c|}
\hline YEAR & \multicolumn{2}{|c|}{ PERSONNEL } & \multicolumn{2}{|c|}{$\begin{array}{c}\text { FONDING } \\
(\$ M 111 \text { IOna) }\end{array}$} & $\begin{array}{l}\text { OTIIITY COST } \\
\text { (\$MIIIIONS) }\end{array}$ \\
\hline & CAPITAI & OPERATIONS & CAPITAL & OPERATIONS & \\
\hline 1994 & 100 & 4,964 & 10.0 & 374.0 & 28.0 \\
\hline 1995 & 90 & 4,700 & 9.0 & 361.0 & 28.0 \\
\hline 1996 & 80 & 4.210 & 8.0 & 332.0 & 28.0 \\
\hline 1997 & 70 & 3,790 & 7.0 & 307.0 & 28.0 \\
\hline 1998 & 60 & 3,090 & 6.0 & 255.0 & 19.0 \\
\hline 1999 & 60 & 2,530 & 6.0 & 213.0 & 19.0 \\
\hline 2000 & 410 & 2,410 & 46.0 & 208.0 & 19.0 \\
\hline 2001 & 830 & 2,410 & 96.0 & 212.0 & 20.0 \\
\hline 2002 & 1,320 & 2,520 & 157.0 & 226.0 & 20.0 \\
\hline 2003 & 1,210 & 2,820 & 147.0 & 259.0 & 20.0 \\
\hline 2004 & 460 & 3,080 & 57.0 & 289.0 & 20.0 \\
\hline 2005 & 60 & 3,360 & 7.0 & 332.0 & 21.0 \\
\hline 2006 & 60 & 3,360 & 7.0 & 329.0 & 21.0 \\
\hline 2007 & 60 & 3,360 & 7.0 & 337.0 & 21.0 \\
\hline 2008 & 60 & 3,310 & 7.0 & 339.0 & 21.0 \\
\hline 2009 & 60 & 3,210 & 8.0 & 336.0 & 22.0 \\
\hline 2010 & 60 & 3,210 & 8.0 & 344.0 & 22.0 \\
\hline 2011 & 60 & 3,210 & 8.0 & 351.0 & 22.0 \\
\hline 2012 & 60 & 3,310 & 8.0 & 359.0 & 22.0 \\
\hline 2013 & 60 & 3,210 & 8.0 & 367.0 & 22.0 \\
\hline 2014 & 60 & 3,210 & 8.0 & 375.0 & 22.0 \\
\hline 2015 & 60 & 3,210 & 9.0 & 383.0 & 23.0 \\
\hline 2016 & 130 & 3,130 & 21.0 & 382.0 & 23.0 \\
\hline 2017 & 130 & 3,150 & 21.0 & 393.0 & 23.0 \\
\hline 2018 & 130 & 3,200 & 21.0 & 409.0 & 23.0 \\
\hline 2019 & 60 & 3,220 & 9.0 & 420.0 & 23.0 \\
\hline 2020 & 60 & 3,280 & 10.0 & 436.0 & 24.0 \\
\hline 2021 & 60 & 3,210 & 10.0 & 437.0 & 24.0 \\
\hline 2022 & 60 & 3,080 & 10.0 & 429.0 & 24.0 \\
\hline 20.23 & 60 & 3,060 & 10.0 & 436.0 & 24.0 \\
\hline 2024 & 60 & 3,080 & 11.0 & 447.0 & 25.0 \\
\hline 2025 & 60 & 3,060 & 11.0 & 454.0 & 25.0 \\
\hline 2026 & 300 & 3,050 & 61.0 & 464.0 & 26.0 \\
\hline 2027 & 540 & 3,050 & 111.0 & 464.0 & 26.0 \\
\hline 2028 & 770 & 3,050 & 162.0 & 484.0 & 26.0 \\
\hline 2029 & 760 & 3,110 & 162.0 & 504.0 & 26.0 \\
\hline 2030 & 280 & 3,120 & 62.0 & 517.0 & 28.0 \\
\hline 2031 & 60 & 3.130 & 12.0 & 530.0 & 33.0 \\
\hline 2032 & 60 & 3,200 & 13.0 & 553.0 & 33.0 \\
\hline 2033 & 60 & 3,170 & 13.0 & 561.0 & 35.0 \\
\hline 2034 & 60 & 3,150 & 13.0 & 570.0 & 35.0 \\
\hline 2035 & 1,030 & 3.050 & 246.0 & 563.0 & 35.0 \\
\hline
\end{tabular}


Section 4

Technical Data sumary supporting the INEL spent guel EIS

Document No. NMP-PLS-930182, Revision 2

March 22,1994

TABLE 12

WASTE AND EMISSIONS DATA FOR CASE 3b

\begin{tabular}{|c|c|c|c|c|c|c|}
\hline YEAR & \multicolumn{5}{|c|}{ WASTE VOLOMES } & EMISSIONS \\
\hline & $\begin{array}{c}\text { CANISTER } \\
\text { (aty.) }\end{array}$ & $\begin{array}{c}\text { SALTCRETE } \\
\text { (cu yds) }\end{array}$ & $\begin{array}{c}\text { II } \\
\text { (cu ft) }\end{array}$ & $\begin{array}{c}\text { SAN I TARY } \\
\text { (Kgal) }\end{array}$ & $\begin{array}{c}\text { TRO - } \\
\text { (cu yds) }\end{array}$ & \\
\hline 1994 & 0 & 0 & 45,000 & 60,768 & 57 & Slight \\
\hline 1995 & 0 & 0 & 45,000 & 57,480 & 57 & Slight \\
\hline 1996 & 5 & 1,500 & 59,000 & 51,480 & 60 & Slight \\
\hline 1997 & 6 & 1,500 & 59,000 & 46,320 & 60 & Slight \\
\hline 1998 & 0 & 0 & 45,000 & 37,800 & 57 & Slight \\
\hline 1999 & 0 & 0 & 20,000 & 31,080 & 20 & Slight \\
\hline 2000 & 0 & 0 & 20,000 & 33,840 & 20 & slight \\
\hline 2001 & 0 & 0 & 20,000 & 38,880 & 20 & Slight \\
\hline 2002 & 0 & 0 & 20,000 & 46,080 & 20 & Slight \\
\hline 2003 & 0 & 0 & 20,000 & 48,360 & 20 & Slight \\
\hline 2004 & 0 & 0 & 20,000 & 42,480 & 20 & Slight \\
\hline 2005 & 0 & 0 & 20,000 & 41.040 & 20 & slight \\
\hline 2006 & 0 & 0 & 20,000 & 41,040 & 20 & Slight \\
\hline 2007 & 0 & 0 & 20,000 & 41,040 & 20 & Slight \\
\hline 2008 & 0 & 0 & 20,000 & 40,440 & 20 & Slight \\
\hline 2009 & 0 & 0 & 20,000 & 39,240 & 20 & Slight \\
\hline 2010 & 0 & 0 & 20.000 & 39,240 & 20 & Slight \\
\hline 2011 & 0 & 0 & 20,000 & 39,240 & 20 & Slight \\
\hline 2012 & 0 & 0 & 20,000 & 40,440 & 20 & Slight \\
\hline 2013 & 0 & 0 & 20,000 & 39,240 & 20 & Slight \\
\hline 2014 & 0 & 0 & 20,000 & 39,240 & 20 & Slight \\
\hline 2015 & 0 & 0 & 20,000 & 39,240 & 20 & Slight \\
\hline 2016 & 0 & 0 & 20,000 & 39,120 & 20 & Slight \\
\hline 2017 & 0 & 0 & 20,000 & 39,360 & 20 & Slight \\
\hline 2018 & 0 & 0 & 20,000 & 39,960 & 20 & Slight \\
\hline 2019 & 0 & 0 & 20,000 & 39,360 & 20 & slight \\
\hline 2020 & 0 & 0 & 20,000 & 40,080 & 20 & SIight \\
\hline 2021 & 0 & 0 & 20,000 & 39,240 & 20 & Slight \\
\hline 2022 & 0 & 0 & 20,000 & 37,680 & 20 & Slight \\
\hline 2023 & 0 & 0 & 20,000 & 37,440 & 20 & slight \\
\hline 2024 & 0 & 0 & 20,000 & 37,680 & 20 & Slight \\
\hline 2025 & 0 & 0 & 20,000 & 37,440 & 20 & Slight \\
\hline 2026 & 0 & 0 & 20,000 & 40,200 & 20 & Slight \\
\hline 2027 & 0 & 0 & 20,000 & 43,080 & 20 & Slight \\
\hline 2028 & 0 & 0 & 20,000 & 45,840 & 20 & Slight \\
\hline 2029 & 0 & 0 & 20,000 & 46,440 & 20 & Slight \\
\hline 2030 & 0 & 0 & 20,000 & 40,800 & 20 & Slight \\
\hline 2031 & 0 & 0 & 20,000 & 38,280 & 20 & Slight \\
\hline 2032 & 24 & 6,500 & 114,000 & 39,120 & 60 & Slight \\
\hline 2033 & 24 & 6,500 & 114,000 & 38,760 & 60 & Slight \\
\hline 2034 & 24 & 6,500 & 114,000 & 38,520 & 60 & slight \\
\hline 2035 & 0 & 0 & 20,000 & 48,960 & 20 & Slight \\
\hline
\end{tabular}




\section{OPTION 3 - PLANNING BASIS}

Case 3c - Provides for the interim dry storage of the SRS spent fuel inventory and the planned receipts of research reactor spent fuels. It develops technology necessary to dry store the spent fuels during the interim storage period. Capabilities to monitor, examine, characterize, and package the spent fuels are provided.

ACTIVITY DESCRIPTION:

SRS proceeds with the spent fuel rearrangement plan described in Case 1 to provide acceptable storage conditions which will minimize the possible failure of the aluminum clad spent fuels prior to interim dry storage.

Placement in a dry storage repository requires an extensive R\&D program which will determine how the spent fuels should be characterized, sampled and examined during the storage period.

SRS will process the solution inventory plus any other materials as required for safety.

The sequence of events in this scenario is as follows:

FY-94 The DOE will initiate the EIS process to support: (1) temporary storage of the spent fuels in one reactor basin and RBOF; (2) interim storage in new dry storage facilities; and (3) processing the solution inventory and other materials for safety.

SRS will begin the R\&D program and preconceptual studies leading toward the Dry Storage Facilities Line Item Project.

FY-95 The DOE will complete the EIS process by issuing a ROD permitting the proposed activities

FY-96 SRS will initiate a Congressional Iine Item project to provide the dry storage facilities.

SRS will embark on an extensive program to renovate a selected reactor basin to improve the water quality. 
SRS will start processing the solution inventory and other materials as required for safety.

SRS can receive some limited offsite shipments.

FY-97 The CDR for the dry storage facilities will be completed.

At the completion of the program to renovate the selected reactor basin, SRS will transfer the SST/Zr clad spent fuels to the selected reactor basin. These positions in RBOF will be backfilled with aluminum clad spent fuels from the other two reactor basins.

EY-98. The rearrangement program will be completed.

The processing of the solution inventory and other materials will be completed.

FY-99 Congress will authorize the dry storage facilities project.

FY-00 The design and construction activities will start.

FY-02 The preparation for the startup activities will begin.

FY-04 Construction will be completed; startup activities can begin. Shipments of the RR spent fuels can resume.

FY-06 After all the readiness reviews are satisfactorily completed the dry storage facilities can begin operations.

FY-07 Receipt of all RR spent fuels will be complete.

FY-10 All the spent fuels will be placed into dry storage. The facilities will be placed into a S\&M mode which will include some monitoring, examination, analysis, and repackaging activities. 
Section 4

Technical Data Sumary supporting the INEL Spent Fuel EIS

Document No. NMP-PLS-930182, Revision 2

varch 22, 1924

EY-21 SRS will initiate the R\&D program necessary to develop the final disposition of the SRS spent fuel inventory.

FY-24 Based on the R\&D program recommendations, SRS will initiate a Congressional Iine Item project to design, construct, and operate the final treatment facility.

FY-25 The CDR for this project will be completed.

EY-27 Congress will authorize the project.

FY-28 The project design and construction activities will begin.

FY-30 Preparation for the startup activities will commence.

FY-32 Construction will be completed.

Startup activities will begin.

FY-33 After all the readiness reviews are satisfactorily completed, the facility will start operations.

FY-34 Processing the spent fuels into the final disposition form will be completed.

EY-35. The facility will be placed into the S\&M mode or made available for other programs.

EACILITIES USED IN THIS CASE:

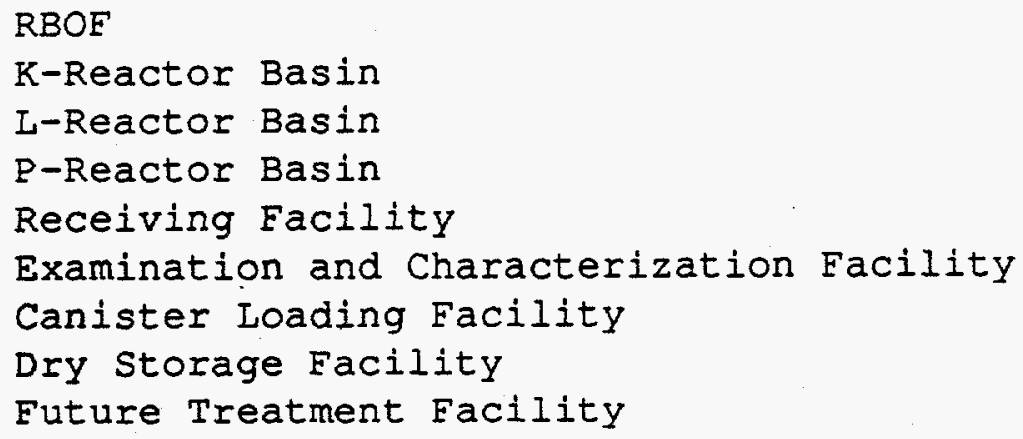


Section 4

Technical Data Summary supporting the INEL spent Fuel eIS

Document No. MMP-PLS-930182, Revision 2

March 22,2924

OPEN ISSUES :

Acceptable resolution of the EIS process which will permit the interim dry storage of the planned spent fuel inventory and the processing of the solutions and other materials as required for safety.

Wet storage of spent fuels is an interim action. No disposition technology exists except some type of future processing. The encapsulation which is necessary to contain the spent fuels through interim dry storage period makes future processing more complex and costly.

The return of the $R R$ spent fuels will be delayed.

Large capital expenditures for the design, construction, then the $D \& D$ of the new facilities are required.

Large annual budgets are required to operate the facilities. 
Section 4

Technical Data Summary supporting the INEL Spent Fuel EIS

Document No. NMP-PLS-930182, Revision 2

March 22, 1294

\section{FIGURE 8}

FLOW CHART FOR CASE $3 C$

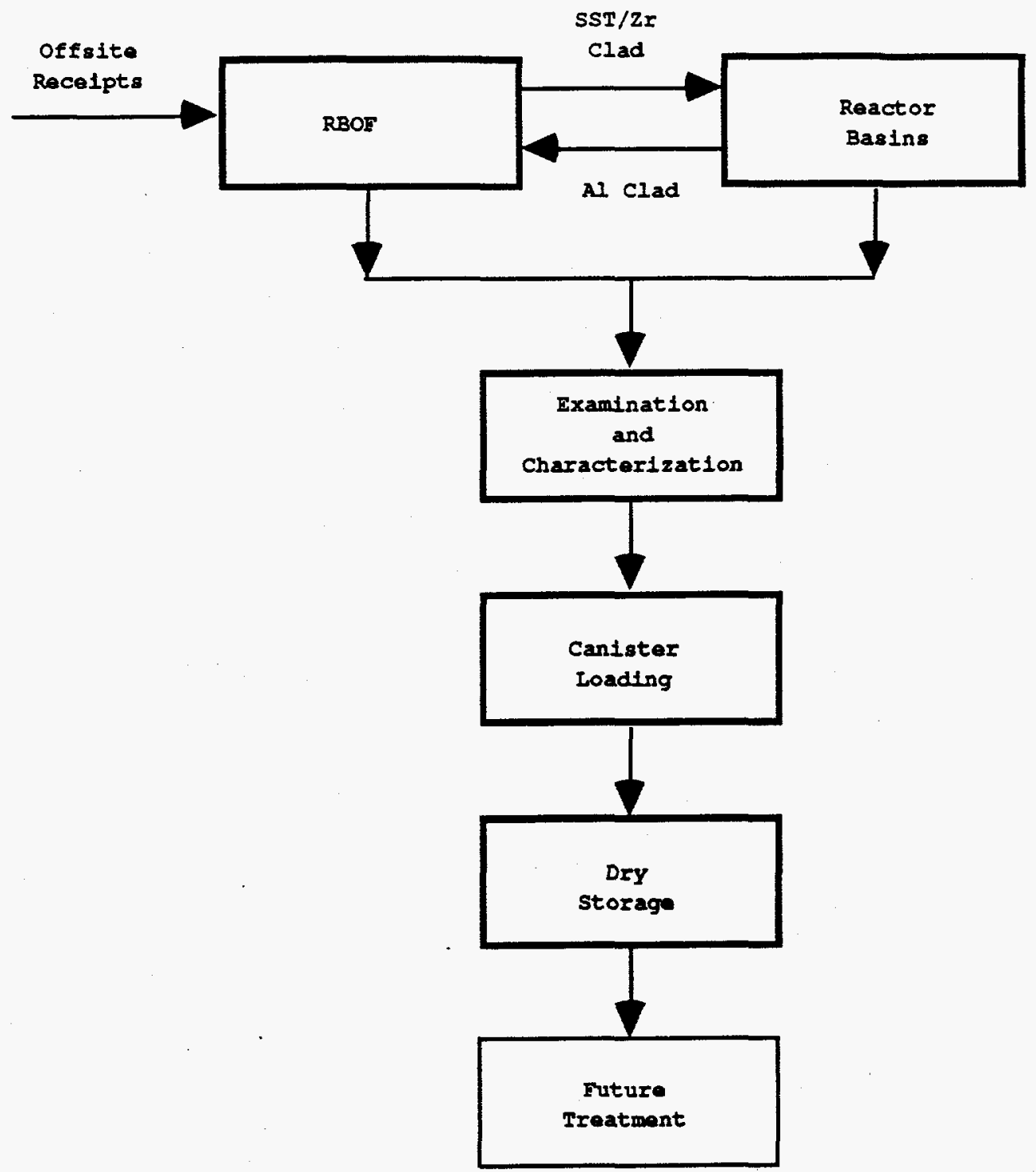


Section 4

Technical Data Sumary supporting the INEL spent Fuel EIS

Document No. NMP-PLS-930182, Revision 2

March 22, 1994

TABLE 13

PERSOMNEL AND COST DATA FOR CASE $3 C$

\begin{tabular}{|c|c|c|c|c|c|}
\hline \multirow[t]{2}{*}{ YEAR } & \multicolumn{2}{|c|}{ PERSONNEL } & \multicolumn{2}{|c|}{$\begin{array}{c}\text { FONDING } \\
\text { (\$M111LOAs) } \\
\end{array}$} & $\begin{array}{c}\text { OTILITY COST } \\
\text { (SMIIIIOns) }\end{array}$ \\
\hline & CAPITAI & OPERATIONS & CARITAI & ORERATIONS & \\
\hline 1994 & 100 & 4,960 & 10.0 & 374.0 & 28.0 \\
\hline 1995 & 90 & 4.820 & 9.0 & 371.0 & 28.0 \\
\hline 1996 & 80 & 4,730 & 8.0 & 372.0 & 28.0 \\
\hline 1997 & 70 & 4,110 & 7.0 & 331.0 & 28.0 \\
\hline 1998 & 60 & 3,790 & 6.0 & 313.0 & 19.0 \\
\hline 1999 & 60 & 3,060 & 6.0 & 258.0 & 19.0 \\
\hline 2000 & 450 & 2,350 & 51.0 & 203.0 & 19.0 \\
\hline 2001 & 790 & 2,350 & 91.0 & 207.0 & 20.0 \\
\hline 2002 & 1.150 & 2,450 & 137.0 & 220.0 & 20.0 \\
\hline 2003 & 1.040 & 2.730 & 127.0 & 251.0 & 20.0 \\
\hline 2004 & 380 & 2,960 & 47.0 & 278.0 & 20.0 \\
\hline 2005 & 60 & 3,170 & 7.0 & 305.0 & 21.0 \\
\hline 2006 & 70 & 3,170 & 7.0 & 311.0 & 21.0 \\
\hline 2007 & 60 & 3,170 & 7.0 & 318.0 & 21.0 \\
\hline 2008 & 60 & 3,150 & 7.0 & 323.0 & 21.0 \\
\hline 2009 & 60 & 3,120 & 8.0 & 327.0 & 22.0 \\
\hline 2010 & 60 & 3,020 & 8.0 & 324.0 & 22.0 \\
\hline 2011 & 140 & 2,880 & 20.0 & 315.0 & 22.0 \\
\hline 2012 & 140 & 2,880 & 20.0 & 322.0 & 22.0 \\
\hline 2013 & 130 & 2.880 & 20.0 & 329.0 & 22.0 \\
\hline 2014 & 60 & 2,880 & 8.0 & 336.0 & 22.0 \\
\hline 2015 & 60 & 2,880 & 9.0 & 344.0 & 23.0 \\
\hline 2016 & 60 & 2,880 & 9.0 & 351.0 & 23.0 \\
\hline 2017 & 60 & 2,880 & 9.0 & 359.0 & 23.0 \\
\hline 2018 & 60 & 2,880 & 9.0 & 367.0 & 23.0 \\
\hline 2019 & 60 & 2,880 & 9.0 & 410.0 & 23.0 \\
\hline 2020 & 60 & 2,880 & 10.0 & 418.0 & 24.0 \\
\hline 2021 & 60 & 2,940 & 10.0 & 436.0 & 24.0 \\
\hline 2022 & 60 & 2,860 & 10.0 & 435.0 & 24.0 \\
\hline 2023 & 60 & 2,790 & 10.0 & 434.0 & 24.0 \\
\hline 2024 & 60 & 2,700 & 11.0 & 427.0 & 25.0 \\
\hline 2025 & 60 & 2,680 & 11.0 & 434.0 & 25.0 \\
\hline 2026 & 60 & 2,700 & 11.0 & 447.0 & 26.0 \\
\hline 2027 & 60 & 2,680 & 11.0 & 454.0 & 26.0 \\
\hline 2028 & 290 & 2,670 & 62.0 & 461.0 & 26.0 \\
\hline 2029 & 520 & 2,580 & 112.0 & 474.0 & 26.0 \\
\hline 2030 & 740 & 2.720 & 162.0 & 492.0 & 28.0 \\
\hline 2031 & 730 & 2,830 & 162.0 & 523.0 & 33.0 \\
\hline 2032 & 270 & 2,870 & 63.0 & 541.0 & 33.0 \\
\hline 2033 & 60 & 2.830 & 13.0 & 546.0 & 35.0 \\
\hline 2034 & 60 & 2,810 & 13.0 & 555.0 & 35.0 \\
\hline 2035 & 940 & 2,750 & 224.0 & 553.0 & 35.0 \\
\hline
\end{tabular}


Section 4

Technical Data Summary supporting the INEL spent Fuel EIS

Document No. NMP-PLS-930182, Revision 2

March 22 - 1294

TABLE 14

WASTE AND EMISSIONS DATA FOR CASE 3C

\begin{tabular}{|c|c|c|c|c|c|c|}
\hline YEAR & \multicolumn{5}{|c|}{ WASTE VOLOMES } & EMISSIONS \\
\hline & $\begin{array}{c}\text { CANISTER } \\
\text { (qty.) }\end{array}$ & $\begin{array}{c}\text { SALTCRETE } \\
\text { (cu yds) }\end{array}$ & $\begin{array}{c}I I \\
(c u f t)\end{array}$ & $\begin{array}{c}\text { SANITARY } \\
\text { (KgaI) }\end{array}$ & $\begin{array}{c}\text { TRO } \\
\text { (cu yds) }\end{array}$ & \\
\hline 1994 & 0 & 0 & 45,000 & 60,768 & 57 & Slight \\
\hline 1995 & 0 & 0 & 45,000 & 57,480 & 57 & Slight \\
\hline 1996 & 5 & 1,500 & 59,000 & 51,480 & 60 & Slight \\
\hline 1997 & 6 & 1,500 & 59,000 & 46,320 & 60 & Slight \\
\hline 1998 & 0 & 0 & 45,000 & 37,800 & 57 & Slight \\
\hline 1999 & 0 & 0 & 20,000 & 31,080 & 20 & Slight \\
\hline 2000 & 0 & 0 & 20,000 & 33,840 & 20 & Slight \\
\hline 2001 & 0 & 0 & 20,000 & 38,880 & 20 & Slight \\
\hline 2002 & 0 & 0 & 20,000 & 46,080 & 20 & Slight \\
\hline 2003 & 0 & 0 & 20,000 & 48,360 & 20 & Slight \\
\hline 2004 & 0 & 0 & 20,000 & 42,480 & 20 & Slight \\
\hline 2005 & 0 & 0 & 20,000 & 41,040 & 20 & Slight \\
\hline 2006 & 0 & 0 & 20,000 & 41,040 & 20 & Slight \\
\hline 2007 & 0 & 0 & 20,000 & 41,040 & 20 & Slight \\
\hline 2008 & 0 & 0 & 20,000 & 40,440 & 20 & Slight \\
\hline 2009 & 0 & 0 & 20,000 & 39,240 & 20 & Slight \\
\hline 2010 & 0 & 0 & 20,000 & 39,240 & 20 & Slight \\
\hline 2011 & 0 & 0 & 20,000 & 39,240 & 20 & Slight \\
\hline 2012 & 0 & 0 & 20,000 & 40,440 & 20 & Slight \\
\hline 2013 & 0 & 0 & 20,000 & 39,240 & 20 & Slight \\
\hline 2014 & 0 & 0 & 20,000 & 39,240 & 20 & Slight \\
\hline 2015 & 0 & 0 & 20,000 & 39,240 & 20 & Slight \\
\hline 2016 & 0 & 0 & 20,000 & 39,120 & 20 & Slight \\
\hline 2017 & 0 & 0 & 20,000 & 39,360 & 20 & Slight \\
\hline 2018 & 0 & 0 & 20,000 & 39,960 & 20 & Slight \\
\hline 2019 & 0 & 0 & 20,000 & 39,360 & 20 & Slight \\
\hline 2020 & 0 & 0 & 20,000 & 40,080 & 20 & Slight \\
\hline 2021 & 0 & 0 & 20,000 & 39,240 & 20 & Slight \\
\hline 2022 & 0 & 0 & 20,000 & 37,680 & 20 & Slight \\
\hline 2023 & 0 & 0 & 20,000 & 37,440 & 20 & Slight \\
\hline 2024 & 0 & 0 & 20,000 & 37,680 & 20 & Slight \\
\hline 2025 & 0 & 0 & 20,000 & 37,440 & 20 & Slight \\
\hline 2026 & 0 & 0 & 20,000 & 40,200 & 20 & Slight \\
\hline 2027 & 0 & 0 & 20,000 & 43,080 & 20 & Slight \\
\hline 2028 & 0 & 0 & 20,000 & 45,840 & 20 & slight \\
\hline 2029 & 0 & 0 & 20,000 & 46,440 & 20 & Slight \\
\hline 2030 & 0 & 0 & 20,000 & 40,800 & 20 & slight \\
\hline 2031 & 0 & 0 & 20,000 & 38,280 & 20 & Slight \\
\hline 2032 & 24 & 6,500 & 114,000 & 39,120 & 60 & Slight \\
\hline 2033 & 24 & 5,500 & 114,000 & 38,760 & 60 & Slight \\
\hline 2034 & 24 & 6,500 & 114,000 & 38,520 & 60 & Slight \\
\hline 2035 & 0 & 0 & 20,000 & 48,960 & 20 & slight \\
\hline
\end{tabular}




\section{OPTION 4 - REGIONALIZATION}

SRS will manage the entire DOE inventory of aluminum clad spent fuels. The SRS SST/Zr clad spent fuels will be shipped to another DOE site for disposition.

\section{SPENT FUEL INVENTORY DESCRIPTION:}

\section{Current Inventories}

Type 2 SRS reactor spent fuels (HEU/AI Clad) including the $\mathrm{Pu}$ targets (DU/Al clad) - $183.6 \mathrm{MTHM}$

Planned Receipts

Type 2 All the aluminum clad spent fuels from university and foreign research reactors as well as the other DOE sites - 19.4 MTHM

\section{Rlanned Shipments}

Type 6a Research reactor SST clad - 11.3 MTHM

Type $6 \mathrm{~b}$ Research reactor $\mathrm{Zr}$ clad - $11.8 \mathrm{MTHM}$ 
Case 4a - Process the existing SRS aluminum clad spent fuels and the $P u$ targets to stabilize the SNM for vault storage. All the receipts of spent fuels will be placed into dry storage. The sRs special clad spent fuels will be shipped to another DOE site for disposition.

ACTIVITY DESCRIPTION:

The SRS separation facilities will be used to process the SRS aluminum clad inventory to safe, stable, and consolidated forms for storage in a product vault.

The Pu targets will be processed in the F-Area facilities using the PUREX Process. The targets will be dissolved in the F-Canyon facility, then the resulting solution transferred to FB-Line for conversion to metal. The resulting DU bearing solution will be converted to oxide in the FA-Line facility.

The existing SRS spent fuel inventory will be processed in $\mathrm{H}-$ Canyon using the HM Process. The HEU bearing solution will be converted to an oxide in the USF. No other SNM will be recovered from the spent fuels.

All the offsite aluminum clad fuels will be stored in new interim dry storage facilities. The receipt of these spent fuels may be delayed until the new facilities are ready.

All the SRS special clad spent fuels will be shipped to another DOE site for disposition. 
Section 4

Technical Data Summary supporting the rNel spent Fuel EIS

Document No. MMP-RIS-930182, Revision 2

March 22, 1924

The activities required for this case are as follows:

E-Area

FY-94 The DOE will initiate the EIS process to permit the reprocessing of the $\mathrm{Pu}$ targets and solutions.

E-Area
FY-94 The DOE will initiate the
EIS process to permit the
reprocessing of the Pu
targets and solutions.

FY-95 DOE will complete the EIS process by issuing the ROD permitting the proposed activities.

FY-96 SRS will start reprocessing the Pu targets and solutions,
The DOE will initiate the EIS process permitting: (1) processing of the aluminum clad spent fuels; (2) transfer of special clad spent fuels to other sites; (3) shipment of the SRS special clad inventory to another site; and (4) interim dry storage of the remaining spent fuel inventory.

SRS will initiate the $R \& D$ program necessary to dry store the RR aluminum clad spent fuels.

DOE will complete the EIS process by issuing the ROD permitting the proposed activities.

Processing the existing SRS aluminum clad spent fuel inventory will begin.

SRS will initiate a Congressional Line Item project to construct the dry storage facilities for the aluminum clad spent fuels from the research reactors and other DOE sites.

Provide more staffing in RBOF to increase fuel handling capability. SRS will start the transfers of the special clad spent fuel inventory to another DOE site. 
FY-97 Reprocessing the Pu targets

will be completed. The

flushing and cleanout

activities will commence.

FY-98 The flushing and cleanout activities will be completed. The F-Area facilities will be placed into the $S \& M$ mode.

H-Canyon completes processing the spent fuels; but processing continues in USF. The H-Canyon and HB-Line facilities will initiate a flushing and cleanout program to achieve a $S \& M$ mode.

Some limited shipments from the research reactors and other DOE sites can be accommodated as space in the storage basins permits.

Congress will authorize the dry storage facilities project.

Processing in the USF will be completed. The flushing and cleanout activities will start.

All H-Area facilities will be in a $S \& M$ mode.

The design and construction activities for the dry storage facilities project will begin.

FY-01 Transfers of the special clad spent fuels to another DOE site will be completed

FY-02 The preparation for the startup activities of the dry storage facilities will commence.

FY-04 Construction of the dry storage facilities will be completed; startup activities will begin. Shipments of the aluminum clad spent fuels from the research reactors and other DOE sites can resume. 
FY-06 After all the readiness reviews are satisfactorily completed, the dry storage facilities will begin operations.

FY-07 All the aluminum clad spent fuels from the research reactors and other DOE sites will be received at SRS.

FY-10 All the spent fuels will be placed into dry storage. The facilities will be placed into a S\&M mode which will include some examination, analysis, and repackaging activities.

FY-21 SRS will initiate the R\&D program necessary to develop the final disposition of the SRS spent fuel inventory.

EY-24 Based on the R\&D program recommendations, SRS will initiate a Congressional line Item project to design, construct, and operate the final treatment facility.

FY-25 The CDR for this project will be completed.

FY-27 Congress will authorize the project.

FY-28 The project design and construction activities will begin.

FY-30 Preparation for the startup activities will commence.

FY-32 Construction will be completed.

Startup activities will begin.

FY-33 After all the readiness reviews are satisfactorily completed, the facility will start operations.

FY-34 Processing the spent fuels into the final disposition form will be completed.

FY-35 The facility will be placed into a S\&M mode. 
Technical Data Summary Supporting the INEL spent Fuel eIS Document No. NMP-PLS-930182, Revision 2

March 22, 1294

FACILITIES USED IN THIS CASE:

RBOF

K-Reactor Basin

L-Reactor Basin

F-Canyon w/PUREX Process

FA-Iine

FB-LIne

H-Canyon w/HM Process

USE

Spent Fuel Receiving Facility

Spent Fuel Examination and Characterization Facility

Canister Loading Facility

Dry Storage Facility

Future Treatment Facility

OPEN ISSUES :

Acceptable resolution of the EIS process to permit the proposed activities.

Any special scientific isotopes contained in spent fuels will not be recovered.

Dry storage of spent fuels is an interim action. No disposition technology exists except some type of future processing. The encapsulation which is necessary to contain the spent fuels through interim dry storage period makes future processing more complex and costly.

The return of the RR spent fuels will be delayed.

Large capital expenditures for the design, construction, then the $D \& D$ of the new facilities are required.

Large annual budgets are required to operate the facilities. 
Section 4

Technical Data summary supporting the INEL spent Fuel EIS Document No. NMP-PLS-930182, Revision 2

March 22, 1924

\section{FIGURE 9}

FLOW CHART FOR CASE 4 a

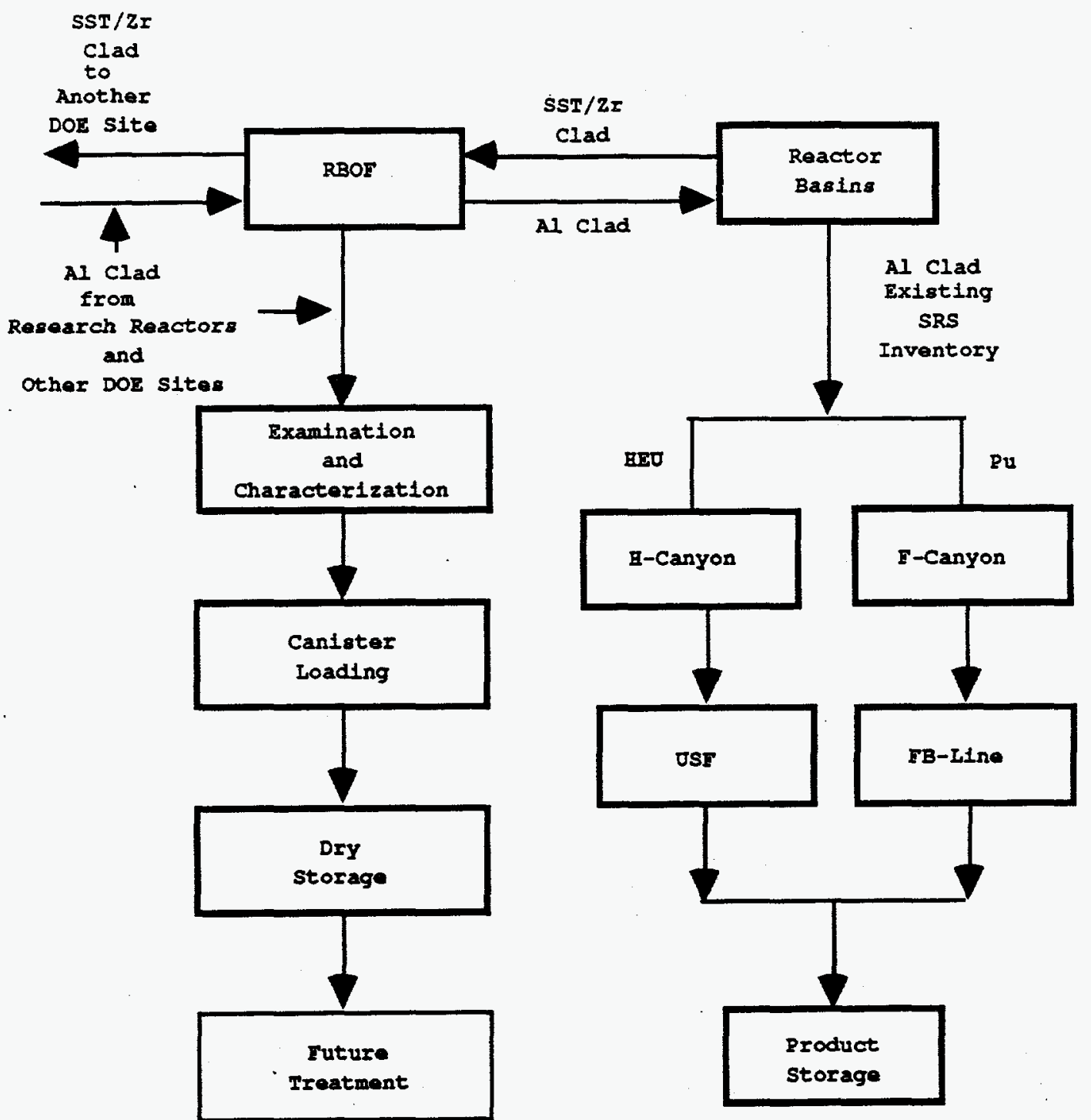


Section

Technical Data Sumary Supporting the INEI spent Euel EIS

Document No. NMP-PLS-930182, Revision 2

Narch 22, 1294

TABLE 15

PERSONNEL AND COST DATA FOR CASE 4 a

\begin{tabular}{|c|c|c|c|c|c|}
\hline YEAR & \multicolumn{2}{|c|}{ PERSONNEL } & \multicolumn{2}{|c|}{$\begin{array}{c}\text { FUNDING } \\
(\$ M 111 \text { IOns) }\end{array}$} & $\begin{array}{c}\text { OTIIITY COST } \\
\text { (\$MIIIIOnS) }\end{array}$ \\
\hline & CAPITAI & OPERATIONS & CAPITAL & OPERATIONS & \\
\hline 1994 & 100 & 4,960 & 10.0 & 374.0 & 28.0 \\
\hline 1995 & 90 & 4,820 & 9.0 & 371.0 & 28.0 \\
\hline 1996 & 80 & 4,730 & 8.0 & 372.0 & 28.0 \\
\hline 1997 & 70 & 4.110 & 7.0 & 331.0 & 28.0 \\
\hline 1998 & 60 & 3,790 & 6.0 & 313.0 & 19.0 \\
\hline 1999 & 60 & 3,060 & 6.0 & 258.0 & 19.0 \\
\hline 2000 & 360 & 2,350 & 41.0 & 203.0 & 19.0 \\
\hline 2001 & 700 & 2,350 & 81.0 & 207.0 & 20.0 \\
\hline 2002 & 1,060 & 2,440 & 127.0 & 220.0 & 20.0 \\
\hline 2003 & 960 & 2,720 & 117.0 & 250.0 & 20.0 \\
\hline 2004 & 300 & 2,950 & 37.0 & 277.0 & 20.0 \\
\hline 2005 & 60 & 3,150 & 7.0 & 303.0 & 21.0 \\
\hline 2006 & 60 & 3,150 & 7.0 & 310.0 & 21.0 \\
\hline 2007 & 60 & 3,150 & 7.0 & 316.0 & 21.0 \\
\hline 2008 & 60 & 3,130 & 7.0 & 321.0 & 21.0 \\
\hline 2009 & 60 & 3,100 & 8.0 & 325.0 & 22.0 \\
\hline 2010 & 60 & 3,010 & 8.0 & 323.0 & 22.0 \\
\hline 2011 & 140 & 2,860 & 20.0 & 314.0 & 22.0 \\
\hline 2012 & 140 & 2,860 & 20.0 & 321.0 & 22.0 \\
\hline 2013 & 130 & 2,860 & 20.0 & 328.0 & 22.0 \\
\hline 2014 & 60 & 2,860 & 8.0 & 335.0 & 22.0 \\
\hline 2015 & 60 & 2,860 & 9.0 & 342.0 & 23.0 \\
\hline 2016 & 60 & 2,860 & 9.0 & 350.0 & 23.0 \\
\hline 2017 & 60 & 2,860 & 9.0 & 357.0 & 23.0 \\
\hline 2018 & 60 & 2,860 & 9.0 & 365.0 & 23.0 \\
\hline 2019 & 60 & 2,860 & 9.0 & 410.0 & 23.0 \\
\hline 2020 & 60 & 2,860 & 10.0 & 418.0 & 24.0 \\
\hline 2021 & 60 & 2,920 & 10.0 & 436.0 & 24.0 \\
\hline 2022 & 60 & 2.850 & 10.0 & 435.0 & 24.0 \\
\hline 2023 & 60 & 2,780 & 10.0 & 434.0 & 24.0 \\
\hline 2024 & 60 & 2,680 & 11.0 & 427.0 & 25.0 \\
\hline 2025 & 60 & 2,670 & 11.0 & 434.0 & 25.0 \\
\hline 2026 & 60 & 2,680 & 11.0 & 447.0 & 26.0 \\
\hline 2027 & 60 & 2,670 & 11.0 & 454.0 & 26.0 \\
\hline 2028 & 290 & 2,650 & 62.0 & 461.0 & 26.0 \\
\hline 2029 & 520 & 2,670 & 112.0 & 474.0 & 26.0 \\
\hline 2030 & 740 & 2,710 & 162.0 & 492.0 & 28.0 \\
\hline 2031 & 730 & 2,820 & 162.0 & 523.0 & 33.0 \\
\hline 2032 & 270 & 2,850 & 63.0 & 541.0 & 33.0 \\
\hline 2033 & 60 & 2,820 & 13.0 & 546.0 & 35.0 \\
\hline 2034 & 60 & 2,800 & 13.0 & 555.0 & 35.0 \\
\hline 2035 & 940 & 2,730 & 224.0 & 553.0 & 35.0 \\
\hline
\end{tabular}


saction 4

Technical Data summary supporting the INJI spent ruel eIs

Document No. NMP-PIS-930182, Revision 2

Narch 22. $\quad 1924$

TABLE 16

WASTE AND EMISSIONS DATA FOR CASE 4 a

\begin{tabular}{|c|c|c|c|c|c|c|}
\hline YEAR & \multicolumn{5}{|c|}{ WASTE VOLOMES } & EMISSIONS \\
\hline & $\begin{array}{c}\text { CANISTER } \\
(\text { qty, })\end{array}$ & $\begin{array}{c}\text { SALTCRETE } \\
\text { (cu yds) }\end{array}$ & $\begin{array}{c}I I \\
(\mathrm{cu} f t)\end{array}$ & $\begin{array}{c}\text { SANITARY } \\
\text { (Kgal) }\end{array}$ & $\begin{array}{c}\text { TRO } \\
\text { (cu yds) }\end{array}$ & \\
\hline 1994 & 0 & 0 & 45,000 & 60,720 & 57 & Slight \\
\hline 1995 & 0 & 0 & 45,000 & 58,920 & 57 & Slight \\
\hline 1996 & 22 & 6,452 & 107,000 & 57,720 & 60 & Slight \\
\hline 1997 & 22 & 6,452 & 107,000 & 50,160 & 60 & Slight \\
\hline 1998 & 23 & 6,452 & 107,000 & 46,200 & 60 & Slight \\
\hline 1999 & 0 & 0 & 45,000 & 37,440 & 20 & Slight \\
\hline 2000 & 0 & 0 & 20,000 & 32,520 & 20 & Slight \\
\hline 2001 & 0 & 0 & 20,000 & 36,600 & 20 & Slight \\
\hline 2002 & 0 & 0 & 20,000 & 42,000 & 20 & Slight \\
\hline 2003 & 0 & 0 & 20,000 & 44,160 & 20 & Slight \\
\hline 2004 & 0 & 0 & 20,000 & 39,000 & .20 & Slight \\
\hline 2005 & 0 & 0 & 20,000 & 38,520 & 20 & Slight \\
\hline 2006 & 0 & 0 & 20,000 & 38,520 & 20 & Slight \\
\hline 2007 & 0 & 0 & 20,000 & 38,520 & 20 & slight \\
\hline 2008 & 0 & 0 & 20,000 & 38,280 & 20 & Slight \\
\hline 2009 & 0 & 0 & 20,000 & 37,920 & 20 & slight \\
\hline 2010 & 0 & 0 & 20,000 & 36,840 & 20 & Slight \\
\hline 2011 & 0 & 0 & 20,000 & 36,000 & 20 & Slight \\
\hline 2012 & 0 & 0 & 20,000 & 36,000 & 20 & Slight \\
\hline 2013 & 0 & 0 & 20,000 & 35,880 & 20 & Slight \\
\hline 2014 & 0 & 0 & 20,000 & 35,040 & 20 & Slight \\
\hline 2015 & 0 & 0 & 20,000 & 35,040 & 20 & Slight \\
\hline 2016 & 0 & 0 & 20,000 & 35,040 & 20 & Slight \\
\hline 2017 & 0 & 0 & 20,000 & 35,040 & 20 & Slight \\
\hline 2018 & 0 & 0 & 20,000 & 35,040 & 20 & Slight \\
\hline 2019 & 0 & 0 & 20,000 & 35,040 & 20 & Slight \\
\hline 2020 & 0 & 0 & 20,000 & 35,040 & 20 & Slight \\
\hline 2021 & 0 & 0 & 20,000 & 35,760 & 20 & Slight \\
\hline 2022 & 0 & 0 & 20,000 & 34,920 & 20 & Slight \\
\hline 2023 & 0 & 0 & 20,000 & 34,080 & 20 & slight \\
\hline 2024 & 0 & 0 & 20,000 & 32,880 & 20 & Slight \\
\hline 2025 & 0 & 0 & 20,000 & 32,760 & 20 & SIight \\
\hline 2026 & 0 & 0 & 20,000 & 32,880 & 20 & Slight \\
\hline 2027 & 0 & 0 & 20,000 & 32,760 & 20 & Slight \\
\hline 2028 & 0 & 0 & 20,000 & 35,280 & 20 & Slight \\
\hline 2029 & 0 & 0 & 20,000 & 38,280 & 20 & Slight \\
\hline 2030 & 0 & 0 & 20,000 & 41,400 & 20 & Slight \\
\hline 2031 & 0 & 0 & 20,000 & 42,600 & 20 & Slight \\
\hline 2032 & 0 & 0 & 20,000 & 37,440 & 20 & Slight \\
\hline 2033 & 0 & 0 & 20,000 & 34,560 & 20 & Slight \\
\hline 2034 & 1 & 236 & 47,334 & 34,320 & 60 & Slight \\
\hline 2035 & 0 & 0 & 20,000 & 44,040 & 20 & Slight \\
\hline
\end{tabular}




\section{OPTION 4 - REGIONALIZATION}

Case 4b - Provides for the interim wet storage of the entire DOE aluminum clad spent fuel inventory. Additional capabilities to monitor, examine, characterize, and repackage the spent fuels are provided.

\section{ACTIVITY DESCRIPTION :}

The water quality in the reactor basins, despite a maintenance program is inadequate for storage of aluminum clad spent fuels. Therefore, the existing SRS spent fuel inventory will be rearranged as in Case 1 to provide temporary wet storage while the new, complying facilities are constructed.

The new wet storage facilities meet all DOE and NRC requirements for SNF and SNM storage. Included in this new storage facilities are the capabilities to examine and characterize spent fuels. All the spent fuels will be encapsulated in a stainless steel canister prior to placement in the new pool. Receipt of aluminum clad fuels from the research reactors and other DOE sites is delayed until the new wet storage facilities are available.

The existing SRS inventory of special clad spent fuels will be shipped to another DOE site for disposition.

The SRS chemical separations facilities will process their solution inventories and other materials as required for safety.

The activities required to fulfill this case are as follows:

FY-94 The DOE will initiate the EIS process to support: (1) temporary storage of spent fuels in a reactor basin and RBOF; (2) interim storage in new wet storage facilities; (3) shipment of the SRS special clad inventory to another site; and (4) processing the solution inventory and other materials as required for safety.

FY-95 The DOE will complete the EIS process by issuing the ROD permitting the proposed activities.

FY-96 SRS will embark on an extensive program to renovate a selected reactor basin to improve water quality.

SRS will initiate a Congressional Line Item project to provide the new wet storage facilities. 
FY-96 SRS will begin processing the solution inventories and other materials as required for safety.

FY-97 At the completion of the program to renovate the selected reactor basin, SRS will relocate the SST/Zr clad spent fuels in the SRS inventory from $R B O F$ to that reactor basin. As these positions in RBOF are emptied, they will be backfilled with aluminum clad spent fuels from the other reactor basins.

The CDR for the new wet storage facilities project will be completed.

FY-98. The rearrangement program will be completed.

Processing in the separation facilities will be completed. The flushing and cleanout activities will begin.

FY-99 Congress will authorize the new wet storage facilities project.

The separations facilities will be placed into a S\&M mode.

FY-00 The design and construction activities for the new wet storage facilities will begin.

FY-02 The preparation for the startup activities of the wet storage facilities will commence.

FY-04 Construction of the wet storage facilities will be completed; startup activities will begin. Shipments of aluminum clad spent fuels from the research reactors and other DOE sites can resume.

EY-06 After all the readiness reviews are satisfactorily completed, the wet storage facilities will begin operations.

EY-07 All the aluminum clad spent fuels from the research reactors and other DOE sites will be received at SRS. 
Technical Data Summary Supporting the INEL spent Fuel EIS

Document No. NMP-PIS-930182, Revision 2

March 22, 1924

EY-10 All the spent fuels will be placed into wet storage. The facilities will be placed into a S\&M mode which will include some monitoring, examination, analysis, and repackaging activities.

FY-21 SRS will initiate the R\&D program necessary to develop the final disposition of the SRS spent fuel inventory.

EY-24 Based on the R\&D program recommendations, SRS will initiate a Congressional Line Item project to design, construct, and operate the final disposition treatment facility.

FY-25 The CDR for this project will be completed.

FY-27. Congress will authorize the project.

FY-28 The project design and construction activities will begin.

FY-30 Preparation for the startup activities will commence.

FY-32 Construction will be completed.

Startup activities will begin.

EY-33. After all the readiness reviews are satisfactorily completed, the facility will start operations.

FY-34 Processing the spent fuels into the final disposition form will be completed.

FY-35 The facility will be placed into a S\&M mode.

\section{FACILITIES USED IN THIS CASE:}

RBOF

K-Reactor Basin

L-Reactor Basin

P-Reactor Basin

Spent Fuel Receiving Facility

Spent Fuel Examination and Characterization Facility

Repackaging Facility

Interim Wet Storage Facility

Future Treatment Facility 
Section 4

Technical Data Summary supporting the INEL Spent Fuel EIS

Document No. NMP-PLS-930182, Revision 2

March 22, 1994

\section{OPEN ISSUES :}

Acceptable resolution of EIS process which will permit the interim storage of the planned spent fuels inventory and the processing of the solutions and other materials as required for safety.

Wet storage of spent fuels is an interim action. No disposition technology exists except some type of future treatment. The encapsulation necessary to prevent failure of the aluminum clad spent fuel cladding through interim wet storage period makes future treatment more complex and costly.

Return of RR fuels will be delayed.

Large capital expenditures for the design, construction, then the $D \& D$ of the new facilities are required.

Large annual budgets are required to operate the facilities. 
Technical Data Summary Supporting the INEI Spent Fuel IIS

Document No. NMP-RLS-930182, Reviston 2

March 22. 1994

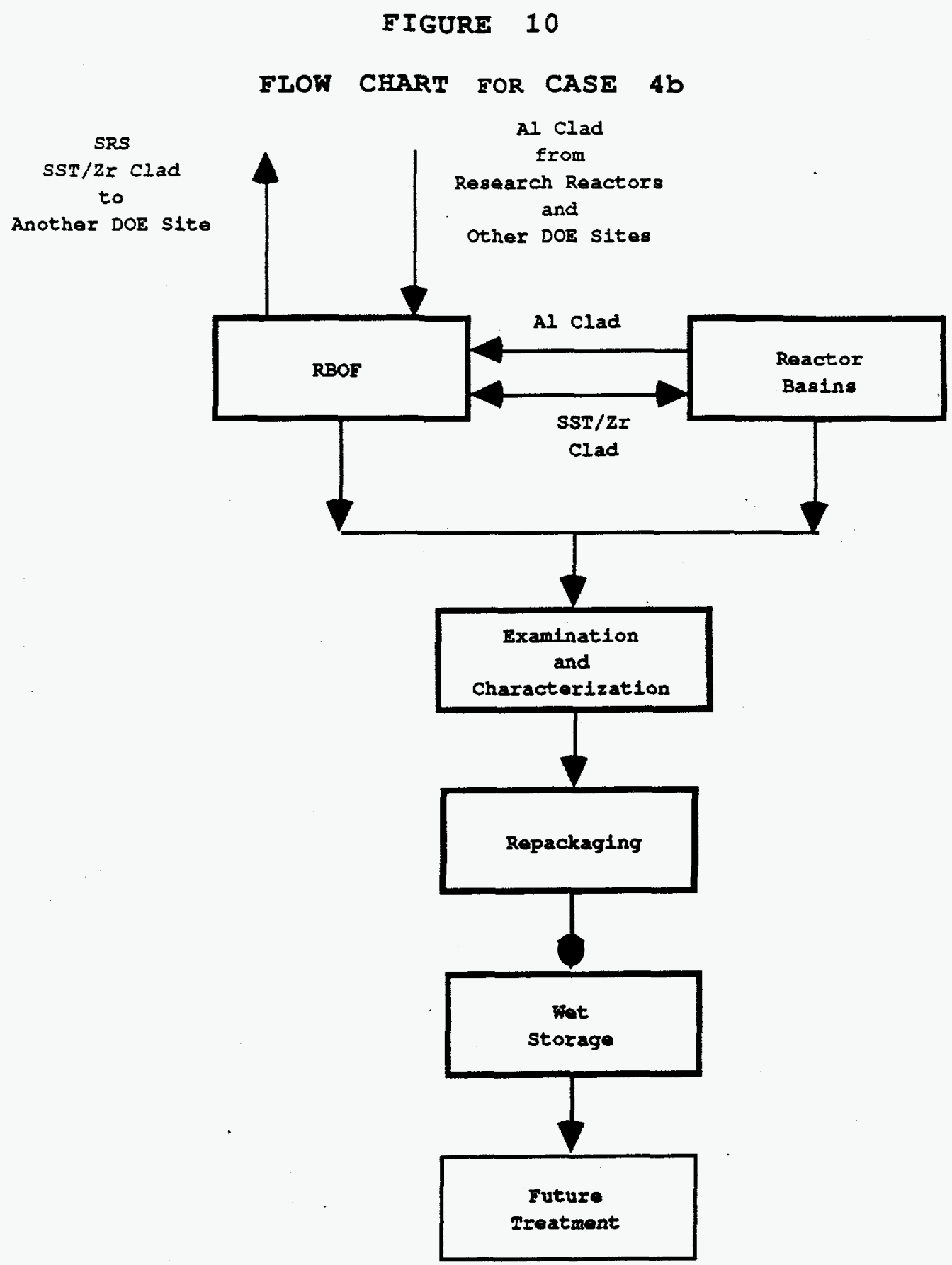


Section 4

Technical Data summary supporting the INEL spent guel EIs

Document No. NMP-PLS-930182, Revision 2

March 22, 1294

TABLE 17

PERSONNEI AND COST DATA FOR CASE 4b

\begin{tabular}{|c|c|c|c|c|c|}
\hline YEAR & \multicolumn{2}{|c|}{ PERSONNEI } & \multicolumn{2}{|c|}{$\begin{array}{c}\text { FONDING } \\
\text { (\$M11110ns) }\end{array}$} & $\begin{array}{l}\text { OTILITY COST } \\
\text { (\$Mill10ns) }\end{array}$ \\
\hline & CAPITAL & OPERATIONS & CAPITAI & OQERATIONS & \\
\hline 1994 & 100 & 4,960 & 10.0 & 374.0 & 28.0 \\
\hline 1995 & 90 & 4,700 & 9.0 & 361.0 & 28.0 \\
\hline 1996 & 80 & 4,210 & 8.0 & 332.0 & 28.0 \\
\hline 1997 & 70 & 3,790 & 7.0 & 307.0 & 28.0 \\
\hline 1998 & 60 & 3,120 & 6.0 & 257.0 & 19.0 \\
\hline 1999 & 60 & 2.530 & 6.0 & 213.0 & 19.0 \\
\hline 2000 & 410 & 2,410 & 46.0 & 208.0 & 19.0 \\
\hline 2001 & 830 & 2,410 & 96.0 & 212.0 & 20.0 \\
\hline 2002 & 1,320 & 2,520 & 157.0 & 226.0 & 20.0 \\
\hline 2003 & 1,210 & 2,820 & 147.0 & 259.0 & 20.0 \\
\hline 2004 & 460 & 3,080 & 57.0 & 289.0 & 20.0 \\
\hline 2005 & 60 & 3,360 & 7.0 & 322.0 & 21.0 \\
\hline 2006 & 60 & 3,360 & 7.0 & 329.0 & 21.0 \\
\hline 2007 & 60 & 3,360 & 7.0 & 337.0 & 21.0 \\
\hline 2008 & 60 & 3,310 & 7.0 & 339.0 & 21.0 \\
\hline 2009 & 60 & 3,210 & 8.0 & 336.0 & 22.0 \\
\hline 2010 & 60 & 3,210 & 8.0 & 344.0 & 22.0 \\
\hline 2011 & 60 & 3,210 & 8.0 & 351.0 & 22.0 \\
\hline 2012 & 60 & 3,210 & 8.0 & 359.0 & 22.0 \\
\hline 2013 & 60 & 3,210 & 8.0 & 367.0 & 22.0 \\
\hline 2014 & 60 & 3,210 & 8.0 & 375.0 & 22.0 \\
\hline 2015 & 60 & 3,210 & 9.0 & 383.0 & 23.0 \\
\hline 2016 & 130 & 3,130 & 21.0 & 382.0 & 23.0 \\
\hline 2017 & 130 & 3,140 & 21.0 & 393.0 & 23.0 \\
\hline 2018 & 130 & 3,200 & 21.0 & 409.0 & 23.0 \\
\hline 2019 & 60 & 3,220 & 9.0 & 420.0 & 23.0 \\
\hline 2020 & 60 & 3,270 & 10.0 & 436.0 & 24.0 \\
\hline 2021 & 60 & 3.210 & 10.0 & 437.0 & 24.0 \\
\hline 2022 & 60 & 3,080 & 10.0 & 429.0 & 24.0 \\
\hline 2023 & 60 & 3,060 & 10.0 & 436.0 & 24.0 \\
\hline 2024 & 60 & 3,080 & 11.0 & 447.0 & 25.0 \\
\hline 2025 & 60 & 3,060 & 11.0 & 454.0 & 25.0 \\
\hline 2026 & 300 & 3.050 & 61.0 & 464.0 & 26.0 \\
\hline 2027 & 540 & 3,050 & 11.0 & 474.0 & 26.0 \\
\hline 2028 & 770 & 3,050 & 162.0 & 484.0 & 26.0 \\
\hline 2029 & 760 & 3,110 & 162.0 & 504.0 & 26.0 \\
\hline 2030 & 280 & 3,120 & 62.0 & 517.0 & 28.0 \\
\hline 2031 & 60 & 3.130 & 12.0 & 530.0 & 33.0 \\
\hline 2032 & 60 & 3,200 & 13.0 & 553.0 & 33.0 \\
\hline 2033 & 60 & 3,170 & 13.0 & 561.0 & 35.0 \\
\hline 2034 & 60 & 3,150 & 13.0 & 570.0 & 35.0 \\
\hline 2035 & 1,030 & 3,050 & 246.0 & 563.0 & 35.0 \\
\hline
\end{tabular}


Section 4

Technical Data Summary Supporting the INEL Spent Fuel EIS

Document No. NMP-PIS-930182, Revision 2

March 22. 1294

TABIE 18

WASTE AND EMISSIONS DATA FOR CASE $4 \mathrm{~b}$

\begin{tabular}{|c|c|c|c|c|c|c|}
\hline YEAR & \multicolumn{5}{|c|}{ WASTE VOLOMES } & ENISSIONS \\
\hline & $\begin{array}{c}\text { CANISTER } \\
\text { (qty.) }\end{array}$ & $\begin{array}{c}\text { SALTCRETE } \\
\text { (cu yds) }\end{array}$ & $\begin{array}{c}\text { IL } \\
\text { (cu ft) }\end{array}$ & $\begin{array}{c}\text { SAN I TARY } \\
\text { (Kgal) }\end{array}$ & $\begin{array}{c}\text { TRU } \\
\text { (cu yds) }\end{array}$ & \\
\hline 1994 & 0 & 0 & 45,000 & 60,720 & 57 & slight \\
\hline 1995 & 0 & 0 & 45,000 & 57,480 & 57 & slight \\
\hline 1996 & 5 & 1,500 & 59,000 & 51,480 & 60 & slight \\
\hline 1997 & 6 & 1,500 & 59,000 & 46,320 & 60 & slight \\
\hline 1998 & 0 & 0 & 45,000 & 38,160 & 20 & slight \\
\hline 1999 & 0 & 0 & 20,000 & 31,080 & 20 & slight \\
\hline 2000 & 0 & 0 & 20,000 & 33,840 & 20 & slight \\
\hline 2001 & 0 & 0 & 20,000 & 38,880 & 20 & slight \\
\hline 2002 & 0 & 0 & 20,000 & 46,080 & 20 & slight \\
\hline 2003 & 0 & 0 & 20,000 & 48,360 & 20 & slight \\
\hline 2004 & 0 & 0 & 20,000 & 42,480 & 20 & slight \\
\hline 2005 & 0 & 0 & 20,000 & 41,040 & 20 & slight \\
\hline 2006 & 0 & 0 & 20,000 & 41,040 & 20 & slight \\
\hline 2007 & 0 & 0 & 20,000 & 41,040 & 20 & slight \\
\hline 2008 & 0 & 0 & 20,000 & 40,440 & 20 & slight \\
\hline 2009 & 0 & 0 & 20,000 & 39,240 & 20 & slight \\
\hline 2010 & 0 & 0 & 20,000 & 39,240 & 20 & slight \\
\hline 2011 & 0 & 0 & 20,000 & 39,240 & 20 & slight \\
\hline 2012 & 0 & 0 & 20,000 & 39,240 & 20 & slight \\
\hline 2013 & 0 & 0 & 20,000 & 39,240 & 20 & slight \\
\hline 2014 & 0 & 0 & 20,000 & 39,240 & 20 & slight \\
\hline 2015 & 0 & 0 & 20,000 & 39,240 & 20 & slight \\
\hline 2016 & 0 & 0 & 20,000 & 39,120 & 20 & slight \\
\hline 2017 & 0 & 0 & 20,000 & 39,240 & 20 & slight \\
\hline 2018 & 0 & 0 & 20,000 & 39,960 & 20 & slight \\
\hline 2019 & 0 & 0 & 20,000 & 39,360 & 20 & slight \\
\hline 2020 & 0 & 0 & 20,000 & 39,960 & 20 & slight \\
\hline 2021 & 0 & 0 & 20,000 & 39,240 & 20 & slight \\
\hline 2022 & 0 & 0 & 20,000 & 37,680 & 20 & slight \\
\hline 2023 & 0 & 0 & 20,000 & 37,440 & 20 & slight \\
\hline 2024 & 0 & 0 & 20,000 & 37,680 & 20 & slight \\
\hline 2025 & 0 & 0 & 20,000 & 37,440 & 20 & slight \\
\hline 2026 & 0 & 0 & 20,000 & 40,200 & 20 & slight \\
\hline 2027 & 0 & 0 & 20,000 & 43,080 & 20 & slight \\
\hline 2028 & 0 & 0 & 20,000 & 45,840 & 20 & slight \\
\hline 2029 & 0 & 0 & 20,000 & 46,440 & 20 & slight \\
\hline 2030 & 0 & 0 & 20,000 & 40,800 & 20 & slight \\
\hline 2031 & 0 & 0 & 20,000 & 38,280 & 20 & slight \\
\hline 2032 & 0 & 0 & 20,000 & 39,120 & 20 & slight \\
\hline 2033 & 23 & 8,296 & 82,605 & 38,760 & 80 & slight \\
\hline 2034 & 24 & 8,296 & 82,604 & 38,520 & 80 & slight \\
\hline 2035 & 0 & 0 & 20,000 & 48,960 & 20 & slight \\
\hline
\end{tabular}




\section{OPTION 4 - REGIONALIZATION \\ Case 4C - Provides interim dry storage for the entire DOE aluminum clad spent fuel inventory. SRS will develop the technology necessary to store the spent fuel during the storage period. Capabilities to monitor, examine, characterize, and package the spent fuels are provided.}

ACTIVITY DESCRIPTION:

The water quality in the reactor basins, despite a maintenance program, is inadequate even for the temporary wet storage of aluminum clad spent fuels. SRS will rearrange the spent fuels as described in case 1 to provide acceptable storage conditions to minimize failure of the aluminum clad spent fuels prior to dry storage.

Dry storage of aluminum clad spent fuels requires an extensive $R \& D$ program to develop the characterization, sampling, and examination parameters. Receipt of aluminum clad fuels from the research reactors and other DOE sites will be delayed until the new dry storage facilities are available.

The special clad spent fuels will be shipped to other DOE sites for disposition.

SRS will process the solution inventories and the other materials as required for safety.

The activities required for this case are as follows:

FY-94 The DOE will initiate the EIS process to support: (1) temporary storage of spent fuels in one reactor basin and RBOF; (2) interim storage in new dry storage facilities; (3) shipment of the SRS SST/Zr inventory to another site; and (4) processing the solution inventories and other materials as required for safety.

SRS will begin R\&D efforts and preconceptual studies for the dry storage facilities project.

FY-95 The DOE will complete the EIS process by issuing the ROD permitting the proposed activities.

FY-96 SRS initiate a Congressional Iine Item project to provide dry storage facilities for the existing SRS aluminum clad spent fuel inventory plus the aluminum clad spent fuels from research reactors and other DOE sites. 
FY-96 SRS will start processing the solution inventories and other materials as required for safety. SRS will embark on an extensive program to renovate a selected reactor basin to improve the water quality.

FY-97 At the completion of the program to renovate the selected reactor basin, SRS will relocate SST/Zr clad spent fuels in the SRS inventory from $R B O F$ to that reactor basin. As SST/Zr assemblies are transferred to the selected reactor basin, these positions in RBOF will be backfilled with $A l$ clad spent fuels from the other two reactor basins.

The CDR for the dry storage facilities project will be completed.

Processing the solution inventories will be completed. The separation facilities will start flushing and cleanout activities.

EY-98 The rearrangement program will be completed.

The separation facilities will be placed in a S\&M mode.

FY-99 Congress will authorize the dry storage facilities project.

FY-00 The design and construction activities for the new dry storage facilities will begin.

FY-02 The preparation for the startup activities of the dry storage facilities will commence.

FY-04 Construction of the wet storage facilities will be completed; startup activities will begin. Shipments of Al clad spent fuels from the research reactors and other DOE sites can resume.

FY-06 After all the readiness reviews are satisfactorily completed, the dry storage facilities will begin operations.

FY-07 All the Al clad spent fuels from the research reactors and other DOE sites will be received at SRS. 
FY-09 All the spent fuels will be placed into dry storage. The facilities will be placed into a S\&M mode which will include some monitoring, examination, analysis, and repackaging activities.

FY-16 SRS will initiate activities to D\&D the excess dry storage facilities.

FY-20 SRS will initiate the R\&D program necessary to obtain the final disposition of the SRS spent fuel inventory.

FY-22. Based on the R\&D program recommendations, SRS will initiate a Congressional Iine Item project to design, construct, and operate the final treatment facility.

FY-23 The CDR for this project will be completed.

FY-25 Congress will authorize the project.

FY-26 The project design and construction activities will begin.

FY-28 Preparation for the startup activities will commence.

FY-30 Construction will be completed.

Startup activities will begin.

EY-32 After all the readiness reviews are satisfactorily completed, the facility will start operations.

FY-34 Processing the spent fuels into the final disposition form will be completed.

FY-35 The facility will be placed into a S\&M mode.

\section{FACILITIES USED IN THIS CASE:}

RBOF

K-Reactor Basin

L-Reactor Basin

Spent Fuel Receiving Facility

Spent Fuel Examination and Characterization Facility

Canister Loading Facility

Interim Dry Storage Facility

Future Treatment Facility 
Technical Data Sumary Supporting the INEL Spent Fuel EIS

Document No. NMP-PLS-930182, Revision 2

March 22. 1924

OPEN ISSUES:

Acceptable resolution of the EIS process which will permit the interim dry storage of the planned spent fuel inventory and the processing of the solutions and the other materials as required for safety.

Dry storage of spent fuels is an interim action. No disposition technology exists except some type of future treatment. The encapsulation necessary to prevent failure of the Al clad spent fuels through interim wet storage period makes future treatment more complex and costly.

Return of the RR spent fuels will be delayed.

Large capital expenditures for the design, construction, then the $D \& D$ of the new facilities are required.

Large annual budgets are required to operate the facilities. 
Section 4

Technical Data sumary supporting the INEL spent Fuel EIS

Document No. NMP-PLS-930182, Revision

March 22. 1994

\section{FIGURE 11}

FLOW CHART FOR CASE $4 \mathrm{C}$

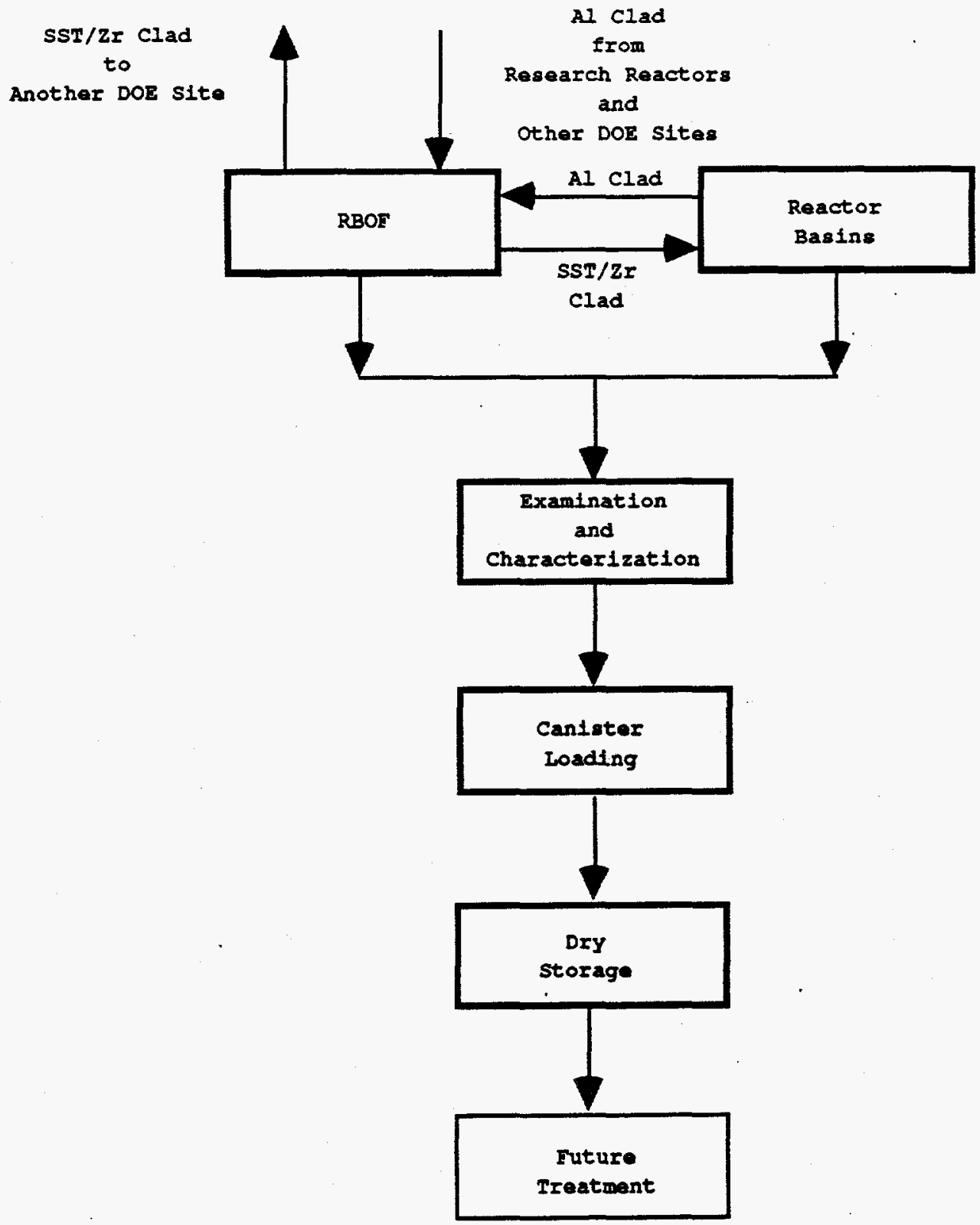


Section 4

Techntcal Data Summary Supporting the INEL spent Fuel EIS

Document No. NMP-PLS-930182, Revision 2

March 22, 2224

TABLE 19

PERSONNEL AND COST DATA FOR CASE $4 \mathrm{C}$

\begin{tabular}{|c|c|c|c|c|c|}
\hline \multirow[t]{2}{*}{ YEAR } & \multicolumn{2}{|c|}{ PERSONNEI } & \multicolumn{2}{|c|}{$\begin{array}{c}\text { FONDING } \\
\text { (\$MIIIIOns) }\end{array}$} & \multirow[t]{2}{*}{$\begin{array}{l}\text { OTIIITY COST } \\
\text { (\$MIIIIONS) }\end{array}$} \\
\hline & CAPITAL & OQERATIONS & CAP ITAL & ORERATIONS & \\
\hline 1994 & 100 & 4,960 & 10.0 & 374.0 & 28.0 \\
\hline 1995 & 90 & 4,700 & 9.0 & 361.0 & 28.0 \\
\hline 1996 & 80 & 4,210 & 8.0 & 332.0 & 28.0 \\
\hline 1997 & 70 & 3.790 & 7.0 & 307.0 & 28.0 \\
\hline 1998 & 60 & 3,120 & 6.0 & 257.0 & 19.0 \\
\hline 1999 & 60 & 2,530 & 6.0 & 213.0 & 19.0 \\
\hline 2000 & 410 & 2,410 & 46.0 & 208.0 & 19.0 \\
\hline 2001 & 830 & 2,410 & 96.0 & 212.0 & 20.0 \\
\hline 2002 & 1,320 & 2,520 & 157.0 & 226.0 & 20.0 \\
\hline 2003 & 1,210 & 2,820 & 147.0 & 259.0 & 20.0 \\
\hline 2004 & 460 & 3,080 & 57.0 & 289.0 & 20.0 \\
\hline 2005 & 60 & 3,360 & 7.0 & 322.0 & 21.0 \\
\hline 2006 & 60 & 3,360 & 7.0 & 329.0 & 21.0 \\
\hline 2007 & 60 & 3,360 & 7.0 & 337.0 & 21.0 \\
\hline 2008 & 60 & 3,310 & 7.0 & 339.0 & 21.0 \\
\hline 2009 & 60 & 3.210 & 8.0 & 336.0 & 22.0 \\
\hline 2010 & 60 & 3,210 & 8.0 & 344.0 & 22.0 \\
\hline 2011 & 60 & 3,210 & 8.0 & 351.0 & 22.0 \\
\hline 2012 & 60 & 3,210 & 8.0 & 359.0 & 22.0 \\
\hline 2013 & 60 & 3,210 & 8.0 & 367.0 & 22.0 \\
\hline 2014 & 60 & 3,210 & 8.0 & 375.0 & 22.0 \\
\hline 2015 & 60 & 3,210 & 9.0 & 383.0 & 23.0 \\
\hline 2016 & 130 & 3,130 & 21.0 & 382.0 & 23.0 \\
\hline 2017 & 130 & 3,150 & 21.0 & 393.0 & 23.0 \\
\hline 2018 & 130 & 3,200 & 21.0 & 409.0 & 23.0 \\
\hline 2019 & 60 & 3,220 & 9.0 & 420.0 & 23.0 \\
\hline 2020 & 60 & 3,270 & 10.0 & 436.0 & 24.0 \\
\hline 2021 & 60 & 3,210 & 10.0 & 437.0 & 24.0 \\
\hline 2022 & 60 & 3,080 & 10.0 & 429.0 & 24.0 \\
\hline 2023 & 60 & 3,060 & 10.0 & 436.0 & 24.0 \\
\hline 2024 & 60 & 3,080 & 11.0 & 447.0 & 25.0 \\
\hline 2025 & 60 & 3,060 & 11.0 & 454.0 & 25.0 \\
\hline 2026 & 300 & 3,050 & 61.0 & 464.0 & 26.0 \\
\hline 2027 & 540 & 3,050 & 111.0 & 474.0 & 26.0 \\
\hline 2028 & 770 & 3,050 & 162.0 & 484.0 & 26.0 \\
\hline 2029 & 760 & 3,110 & 162.0 & 504.0 & 26.0 \\
\hline 2030 & 280 & 3,120 & 62.0 & 517.0 & 28.0 \\
\hline 2031 & 60 & 3,130 & 12.0 & 530.0 & 33.0 \\
\hline 2032 & 60 & 3,200 & 13.0 & 553.0 & 33.0 \\
\hline 2033 & 60 & 3,170 & 13.0 & 561.0 & 35.0 \\
\hline 2034 & 60 & 3,150 & 13.0 & 570.0 & 35.0 \\
\hline 2035 & 1,030 & 3,050 & 246.0 & 563.0 & 35.0 \\
\hline
\end{tabular}


Section 4

Technical Data summary supporting the IrgI spent Fuel EIS

Document No. NMP-PIS-930182, Revision 2

Narch 22, 1924.

TABLE 20

WASTE AND EMISSIONS DATA FOR CASE 4C

\begin{tabular}{|c|c|c|c|c|c|c|}
\hline YEAR & \multicolumn{5}{|c|}{ FASTE VOLUMES } & EMISSIONS \\
\hline & $\begin{array}{c}\text { CANISTER } \\
\text { (gty.) }\end{array}$ & $\begin{array}{c}\text { SALTCRETE } \\
\text { (cu yas) }\end{array}$ & $\begin{array}{c}\mathbf{L} \mathbf{L} \\
(\mathrm{cu} \quad \mathrm{ft})\end{array}$ & $\begin{array}{c}\text { SANITARY } \\
\begin{array}{c}\text { (Kgal) } \\
\end{array}\end{array}$ & $\begin{array}{c}\text { TRO } \\
\text { (cu yds) }\end{array}$ & \\
\hline 1994 & 0 & 0 & 45,000 & 60,720 & 57 & Slight \\
\hline 1995 & 0 & 0 & 45,000 & 57,480 & 57 & Slight \\
\hline 1996 & 5 & 1,500 & 59,000 & 51,480 & 60 & Slight \\
\hline 1997 & 6 & 1,500 & 59,000 & 46,320 & 60 & Slight \\
\hline 1998 & 0 & 0 & 45,000 & 38,160 & 20 & Slight \\
\hline 1999 & 0 & 0 & 20,000 & 31,080 & 20 & Slight \\
\hline 2000 & 0 & 0 & 20,000 & 33,840 & 20 & Slight \\
\hline 2001 & 0 & 0 & 20,000 & 38,880 & 20 & Slight \\
\hline 2002 & 0 & 0 & 20,000 & 46,080 & 20 & Slight \\
\hline 2003 & 0 & 0 & 20,000 & 48,360 & 20 & Slight \\
\hline 2004 & 0 & 0 & 20,000 & 42,480 & 20 & Slight \\
\hline 2005 & 0 & 0 & 20,000 & 41,040 & 20 & Slight \\
\hline 2006 & 0 & 0 & 20,000 & 41,040 & 20 & Slight \\
\hline 2007 & 0 & 0 & 20,000 & 41,040 & 20 & Slight \\
\hline 2008 & 0 & 0 & 20,000 & 40,440 & 20 & slight \\
\hline 2009 & 0 & 0 & 20,000 & 39,240 & 20 & Slight \\
\hline 2010 & 0 & 0 & 20,000 & 39,240 & 20 & Slight \\
\hline 2011 & 0 & 0 & 20,000 & 39,240 & 20 & Slight \\
\hline 2012 & 0 & 0 & 20,000 & 39,240 & 20 & Slight \\
\hline 2013 & 0 & 0 & 20,000 & 39,240 & 20 & slight \\
\hline 2014 & 0 & 0 & 20,000 & 39,240 & 20 & Slight \\
\hline 2015 & 0 & 0 & 20,000 & 39,240 & 20 & slight \\
\hline 2016 & 0 & 0 & 20,000 & 39,120 & 20 & Slight \\
\hline 2017 & 0 & 0 & 20,000 & 39,360 & 20 & slight \\
\hline 2018 & 0 & 0 & 20,000 & 39,960 & 20 & slight \\
\hline 2019 & 0 & 0 & 20,000 & 39,360 & 20 & Slight \\
\hline 2020 & 0 & 0 & 20,000 & 39,960 & 20 & Slight \\
\hline 2021 & 0 & 0 & 20,000 & 39,240 & 20 & slight \\
\hline 2022 & 0 & 0 & 20,000 & 37,680 & 20 & Slight \\
\hline 2023 & 0 & 0 & 20,000 & 37,440 & 20 & Slight \\
\hline 2024 & 0 & 0 & 20,000 & 37,680 & 20 & Slight \\
\hline 2025 & 0 & 0 & 20,000 & 37,440 & 20 & Slight \\
\hline 2026 & 0 & 0 & 20,000 & 40,200 & 20 & slight \\
\hline 2027 & 0 & 0 & 20,000 & 43,080 & 20 & Slight \\
\hline 2028 & 0 & 0 & 20,000 & 45,840 & 20 & slight \\
\hline 2029 & 0 & 0 & 20,000 & 46,440 & 20 & slight \\
\hline 2030 & 0 & 0 & 20,000 & 40,800 & 20 & Slight \\
\hline 2031 & 0 & 0 & 20,000 & 38,280 & 20 & Slight \\
\hline 2032 & 0 & 0 & 20,000 & 39,120 & 20 & Slight \\
\hline 2033 & 23 & 8,296 & 82,605 & 38,760 & 80 & Slight \\
\hline 2034 & 24 & 8,296 & 82,604 & 38,520 & 80 & Slight \\
\hline 2035 & 0 & 0 & 20,000 & 48,960 & 20 & Slight \\
\hline
\end{tabular}


Section

Technical Data Summary supporting the INEL Spent Fuel EIS

Document No. NMP-PLS-930182, Revision 2

March 22,1994

\section{OPTION 5 - CENTRAIIZATION}

SRS will manage the entire DOE spent fuel inventory.

SPENT FUEL INVENTORY DESCRIPTION:

Current Inventories

Type 2 SRS reactor spent fuel (HEU/Al clad) including Pu targets (DU/Al clad) $-183.6 \mathrm{MTHM}$

Type 6a Research reactor SST Clad - 11.3 MTHM

Type 6b Research reactor $\mathrm{Zr}$ clad - 11.8 MTHM

Planned Receipts

Type 1 Naval reactor spent fuels - 19.7 MTHM

Type 2 Al clad research reactor spent fuels - 15.0 MTHM

Type 2 Al clad spent fuel from other DOE sources - 4.4 MTHM

Type 3 Hanford defense spent fuels - 2103.4 MTHM

Type 4 Graphite type spent fuels - 29.3 MTHM

Type 5 Commercial type spent fuels - 166.7 MTHM

Type $6 a$ Research reactor SST Clad spent fuels - 62.1 MTHM

Type $6 \mathrm{~b}$ Research reactor $\mathrm{Zr}$ clad spent fuels - 58.9 MTHM

Type 6c Other RR special clad spent fuels - 0.9 MTHM 
Technical Data Summary supporting the INEI spent ruel IIS

Document No. MMP-PLS-930182, Revision 2

March 22. 1994

\section{OPTION 5 - CENTRALIZATION}

Case 5a - SRS will process the current sRS Al clad spent fuel and Pu target inventory to stabilize the SNM for vault storage. The balance of the entire DOE spent fuel inventory will be placed into new dry storage facilities.

\section{ACTIVITY DESCRIPTION :}

The SRS separations facilities will be used to process the current SRS Al clad spent fuel and Pu target inventory to safe, stable, and consolidated forms for storage in a product vault.

The Pu targets will be processed in the F-Area facilities using the PUREX Process. The targets will be dissolved, the purified in the F-Canyon Facility. The resulting Pu bearing solutions will be converted to metal in FB-Line. The DU bearing solution will be converted to oxide in the FA-Line Facility.

The spent fuels will be processed in H-Canyon using the HM Process which was designed for aluminum clad fuels containing HEU. The HEU solutions will be converted to an oxide in the USF.

The SRS special clad spent fuel inventory along with all the other DOE spent fuel inventory will be stored in new dry storage facilities for the interim period.

The activities required to implement this case are as follows:

\section{E-Area}

FY-94 The DOE will initiate the EIS process to permit the processing of the Pu targets and solutions.
FY-95 The DOE will complete the EIS process by issuing the ROD permitting the proposed activities.

\section{H-Area}

The DOE will initiate the EIS process to support: (1) storage of the planned spent fuel inventory in new facilities at SRS; (2) process the SRS Al clad inventory; and (3) temporary storage of the remaining SRS inventory.

The DOE will complete the EIS process by issuing the ROD permitting the proposed activities. 


\section{E-Area}

$F Y-96$

SRS will start

the Pu targets and

solutions.

FY-96 SRS will start reprocessing
the Pu targets and
solutions.

FY-97 Reprocessing the Pu targets
will be completed. The
flushing and cleanout
activities will commence.

FY-98 The F-Area facilities will be placed into the S\&M mode.

FY -99

FY-00
H-Area will begin processing the spent fuels.

Complete the startup activities for the USF.

SRS can resume some limited receipts of spent fuels.

The CDR for the new dry storage facilities project will be completed.

Processing the spent fuels will be completed. USF will continue operations. HCanyon and HB-Line will start flushing and cleanout activities.

Congress will authorize the new dry storage facilities project.

Complete processing in USF. USF will start flushing and cleanout activities.

Design and construction activities for the new dry storage facilities project will commence.

H-Area facilities will be placed into the $S \& M$ mode.

FY-03 Preparations for the startup activities will commence.

EY-04 A fully integrated production plan for the new dry storage facilities will start into development in conjunction with a plan for full resumption of spent fuel shipments to SRS. 
EY-06 Construction of the new dry storage facilities will be completed. Startup activities will begin.

FY-08 After all the readiness reviews are satisfactorily completed, the dry storage facilities will begin operations. The spent fuel shipment plan will commence.

FY-14 SRS will initiate an R\&D program to develop the final disposition for the spent fuels.

FY-20 The dry storage operations will be completed. The facilities will be placed into a S\&M mode which will include some examination, repackaging and monitoring activities.

FY-16 Based on the results from the R\&D program, SRS will develop a Congressional Line Item project to provide the facilities necessary for the final disposition.

FY-17 The CDR for the final disposition project will be completed.

FY-20 Congress will authorize the final disposition project.

FY-21 Design and construction activities for the final disposition project will begin.

FY-23 Preparations for the startup activities will commence.

FY-25 The construction of the new dry facilities will be completed. Startup activities will begin.

D\&D activities for the excess dry storage facilities will begin.

FY-28 After satisfactory completion of the readiness reviews, the dry facilities will begin operations.

FY-33 The final treatment processing will be completed. Flushing and cleanout activities will start.

FY-35 The treatment facility and the remainder of the dry storage facilities will be placed into a S\&M mode. 


\section{EACILITIES INVOLVED IN THIS CASE:}

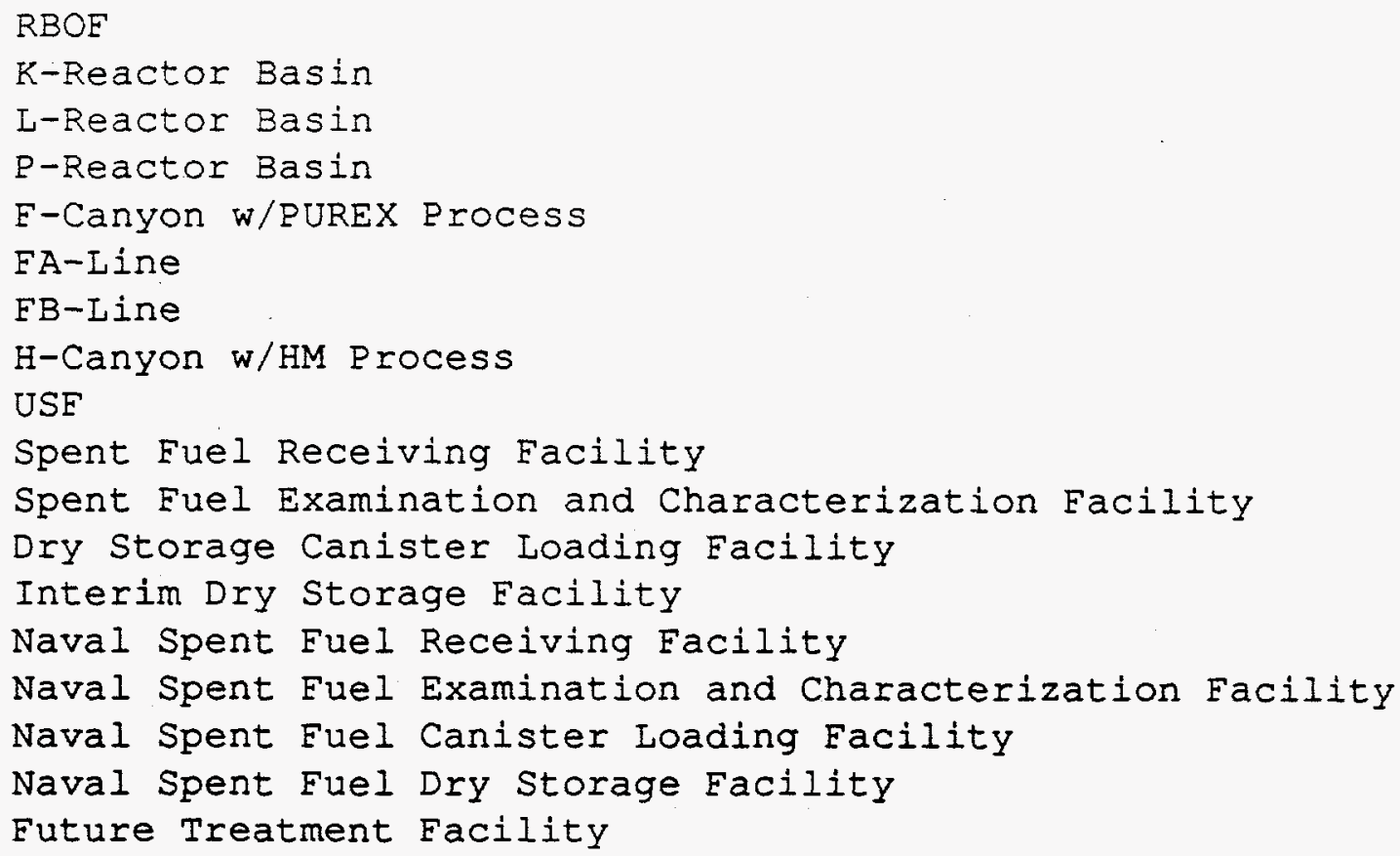

OPEN ISSUES :

Acceptable resolution of the EIS process which will permit the interim dry storage of the planned spent fuels inventory and processing the SRS Al clad inventory.

Fuel storage is an interim action. No disposition technology exists except some type of future treatment. The encapsulation necessary to prevent failure of the aluminum clad spent fuels through interim dry storage period makes future treatment more complex and costly.

Return of the $R R$ fuels would be significantly delayed.

Massive capital expenditures for the design, construction, then the $D \& D$ of the new facilities are required.

Massive annual budgets are required to operate the facilities at SRS and the other DOE sites.

Extensive shipping of the spent fuels is required.

The public willingness to store spent fuels without a technically developed disposition is not known at this time. 
Section 4

Technical Data Summary Supporting the INEL Spent Fuel EIS

Document No. MMP-PLS-930182, Revision 2

March 22, 2924

\section{FIGURE 12}

FLOW CHART FOR CASE 5a

SRS

Inventory
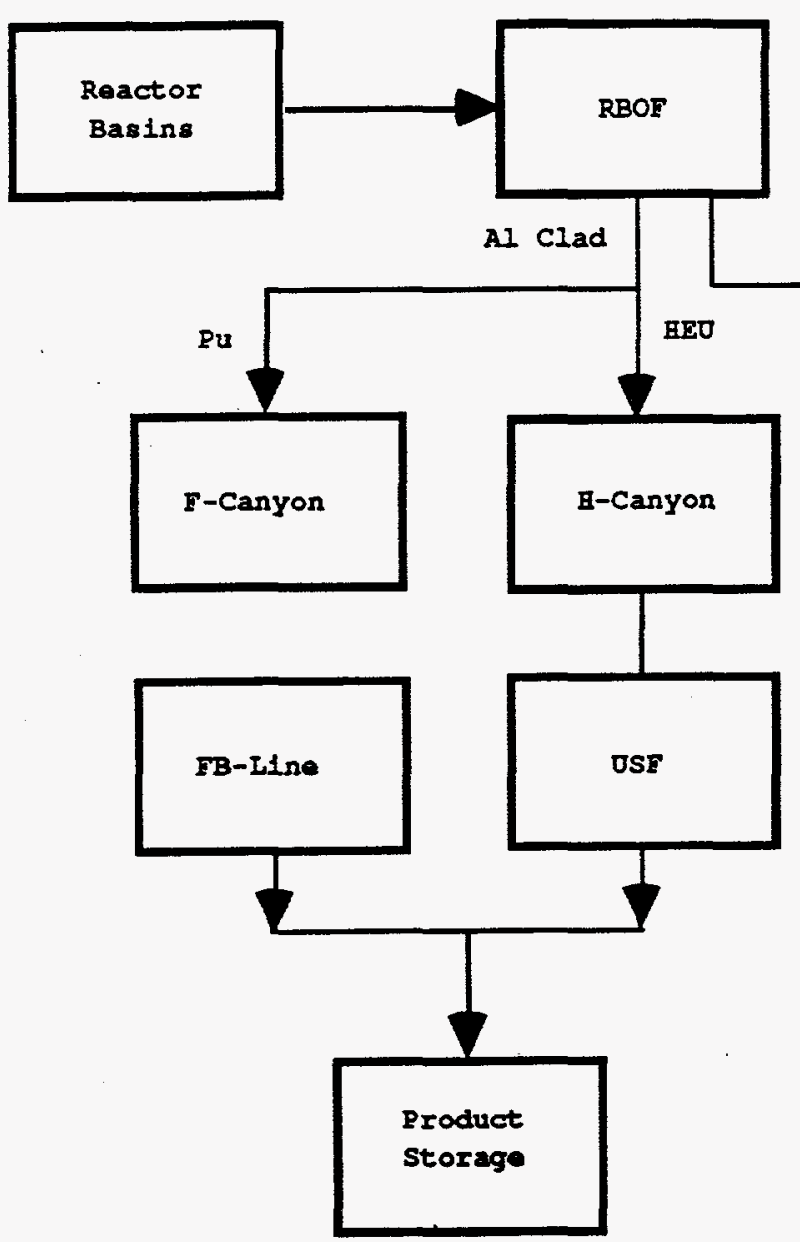

Al Clad
All Other DOE

Spent Fuels

Except Naval.

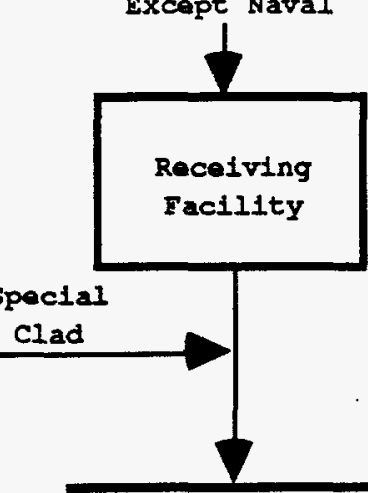

Examination

and

Charaterization

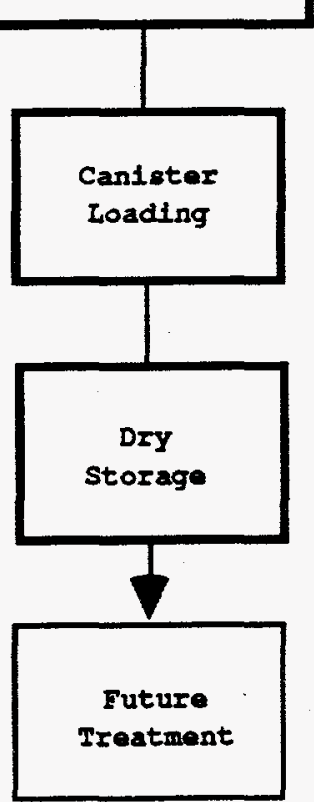

Naval

Fuels

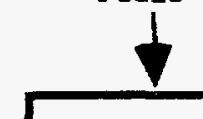

Receiving

Facility

Examination

and

Charaterization

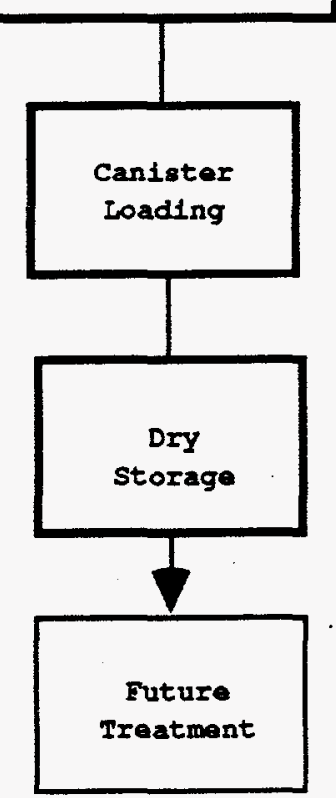


Technical Data summary supporting the INEI spent Fuel aIs

Document No. NMP-PLS-930182, Revision 2

March 22, 1294

TABLE 22

WASTE AND EMISSIONS DATA FOR CASE 5 a

\begin{tabular}{|c|c|c|c|c|c|c|}
\hline \multirow[t]{2}{*}{ YEAR } & \multicolumn{5}{|c|}{ WASTE VOLUMES } & \multirow[t]{2}{*}{ EMISSIONS } \\
\hline & $\begin{array}{c}\text { CANISTER } \\
\text { (qty.) }\end{array}$ & $\begin{array}{c}\text { SALTCRETE } \\
\text { (cu yds) }\end{array}$ & $\begin{array}{c}\mathrm{LI} \\
(\mathrm{cu} f \mathrm{ft})\end{array}$ & $\begin{array}{l}\text { SANITARY } \\
\text { (Kgal) }\end{array}$ & $\begin{array}{c}\text { TRO. } \\
\text { (cL yds) }\end{array}$ & \\
\hline 1994 & 0 & 0 & 45,000 & 60,720 & 57 & slighe \\
\hline 1995 & 0 & 0 & 45,000 & 58,920 & 57 & slight \\
\hline 1996 & 16 & 4.839 & 91,000 & 58,560 & 65 & slight \\
\hline 1997 & 17 & 4,839 & 91,000 & 51,000 & 65 & slight \\
\hline 1998 & 17 & 4.839 & 91,000 & 46,920 & 65 & sight \\
\hline 1999 & 17 & 4,839 & 91,000 & 38,880 & 65 & slight \\
\hline 2000 & 0 & 0 & 45,000 & 51,120 & 57 & slight \\
\hline 2001 & 0 & 0 & 20,000 & 72,720 & 20 & slight \\
\hline 2002 & 0 & 0 & 20,000 & 94,800 & 20 & slight \\
\hline 2003 & 0 & 0 & 20,000 & 101,880 & 20 & slight \\
\hline 2004 & 0 & 0 & 20.000 & 106.080 & 20 & slight \\
\hline 2005 & 0 & 0 & 20,000 & 88,560 & 20 & slight \\
\hline 2006 & 0 & 0 & 20,000 & 74,520 & 20 & slight \\
\hline 2007 & 0 & 0 & 20,000 & 56,520 & 20 & slight \\
\hline 2008 & 0 & 0 & 20,000 & 56,160 & 20 & slight \\
\hline 2009 & 0 & 0 & 20,000 & 55,920 & 20 & slight \\
\hline 2010 & 0 & 0 & 20,000 & 55,560 & 20 & slight \\
\hline 2011 & 0 & 0 & 20,000 & 55,560 & 20 & slight \\
\hline 2012 & 0 & 0 & 20,000 & 55,200 & 20 & slight \\
\hline 2013 & 0 & 0 & 20,000 & 54,720 & 20 & slight \\
\hline 2014 & 0 & 0 & 20.000 & 53,880 & 20 & slight \\
\hline 2015 & 0 & 0 & 20,000 & 53,880 . & 20 & slight \\
\hline 2016 & 0 & 0 & 20,000 & 53,880 & 20 & slight \\
\hline 2017 & 0 & 0 & 20,000 & 53,880 & 20 & slight \\
\hline 2018 & 0 & 0 & 20,000 & 53,880 & 20 & slight \\
\hline 2019 & 0 & 0 & 20,000 & 53,880 & 20 & slight \\
\hline 2020 & 0 & 0 & 20,000 & 53,880 & 20 & slight \\
\hline 2021 & 0 & 0 & 20,000 & 40,440 & 20 & slight \\
\hline 2022 & 0 & 0 & 20,000 & 40,440 & 20 & slight \\
\hline 2023 & 0 & 0 & 20,000 & 40,440 & 20 & slight \\
\hline 2024 & 0 & 0 & 20,000 & 40,440 & 20 & slight \\
\hline 2025 & 0 & 0 & 20,000 & 47,040 & 20 & slight \\
\hline 2026 & 0 & 0 & 20,000 & 47,880 & 20 & slight \\
\hline 2027 & 0 & 0 & 20,000 & 47.880 & 20 & slight \\
\hline 2028 & 29 & 5,978 & 104,198 & 47,880 & 60 & slight \\
\hline 2029 & 29 & 5,978 & 104,198 & 44,640 & 60 & slight \\
\hline 2030. & 29 & 5,978 & 104,198 & 44,640 & 60 & slight \\
\hline 2031 & 29 & 5,978 & 104,198 & 44,640 & 60 & slight \\
\hline 2032 & 29 & 5,978 & 104.198 & 44,640 & 60 & slight \\
\hline 2033 & 29 & 5,978 & 104,198 & 45,840 & 60 & slight \\
\hline 2034 & 0 & 0 & 20,000 & 49.440 & 20 & slight \\
\hline 2035 & 0 & 0 & 20,000 & 64,800 & 20 & slight \\
\hline
\end{tabular}


Section 4

Page 93 of 170

Technical Data summary supporting the INEI spent Fuel EIS

Document No. MMP-PLS-930182, Revision 2

March $22 \quad 1924$

FY-96 SRS will initiate a Congressional Line Item project to provide the new wet storage facilities.

SRS will embark on an activity to renovate a reactor basin as part of the rearrangement program for the current SRS spent fuel inventory.

SRS will begin processing the solution inventories.

FY-97 At the completion of the program to renovate a selected reactor basin, SRS will relocate the SST/Zr spent fuels in the SRS inventory from RBOF to that reactor basin. As SST/Zr assemblies are transferred to the selected reactor basin, these positions in RBOF will be backfilled with aluminum clad spent fuels from the other two reactor basins.

The CDR for the new wet storage facilities project will be completed.

FY-98 The rearrangement program will be completed.

FY-99 Congress will authorize the new wet storage facilities project.

FY-00 Design and construction activities for the new wet storage facilities will commence.

FY-03 Preparations for the startup activities will commence.

FY-04 A fully integrated production plan for the new wet storage facilities will start into development in conjunction with a plan for full resumption of spent fuel shipments to SRS.

FY-06 Construction of the new wet storage facilities will be completed. Startup activities will begin.

FY-08 After all the readiness reviews are satisfactorily completed, the wet storage facilities will begin operations. The spent fuel shipment plan will commence. 
Section 4

Technical Data summary Supporting the INEL spent Fuel EIS

Document No. NMP-PIS-930182, Revision 2

March 22, 2924

FY-14 SRS will initiate an R\&D program to develop the final disposition for the spent fuels.

FY-16 Based on the results from the R\&D program, SRS will develop a Congressional Line Item project to provide the facilities necessary for the final disposition.

FY-17 The CDR for the final disposition project will be completed.

FY-20 The wet storage operations will be completed. The facilities will be placed into the S\&M mode which will include some examination, repackaging and monitoring activities.

Congress will authorize the final disposition facility project.

FY-21 Design and construction activities for the final disposition facility project will begin.

FY-23 Preparations for the startup activities will commence.

FY-25 The construction of the final disposition facility will be completed. Startup activities will begin.

D\&D activities for the excess wet storage facilities will begin.

FY-28 After satisfactory completion of the readiness reviews, the final disposition facility will begin operations.

The D\&D activities of the excess wet storage facilities will be completed.

FY-33 The final treatment processing will be completed. Flushing and cleanout activities will start.

FY-35 The final disposition facility and the remainder of the wet storage facilities will be placed into a S\&M mode. 
Section 4

Technical Data summary supporting the INEL spent Fuel EIS

Document No. MMP-PIS-930182, Revision 2

March 22.1924

FACILITIES USED IN THIS CASE:

RBOF
K-Reactor Basin
L-Reactor Basin
P-Reactor Basin

Spent Fuel Receiving Facility

Spent Fuel Examination and Characterization Facility

Dry Storage Canister Loading Eacility

Interim Dry Storage Eacility

Naval Spent Euel Receiving Facility

Naval Spent Fuel Examination and Characterization Facility

Naval Spent Fuel Canister Loading Facility

Naval Spent Fuel Dry Storage Facility

Euture Treatment Facility

OPEN ISSUES :

Acceptable resolution of the EIS process which will permit the interim wet storage of the planned spent fuels inventory and processing the SRS solution inventories and the other materials as required for safety.

Wet storage of spent fuels is an interim action. No disposition technology exists except some type of future treatment. The encapsulation necessary to prevent failure of the aluminum clad spent fuel cladding through interim wet storage period makes future treatment more complex and costly.

Return of the FRR spent fuels would be significantly delayed.

Massive capital expenditures for the design, construction, then the $D \& D$ of the new facilities are required.

Massive annual budgets are required to operate the facilities at SRS and the other DOE sites.

Extensive shipping of the spent fuels is required.

The public willingness to store spent fuels without a technically developed disposition is not known at his time. 
Section 4

Technical Data Summary Supporting the INEL spent Fuel EIS

Document No, NMP-PLS-930182, Revision 2

March 22, 1924

FIGURE 13

FLOW CHART FOR CASE 5b

SRS Inventory

SST/ZI

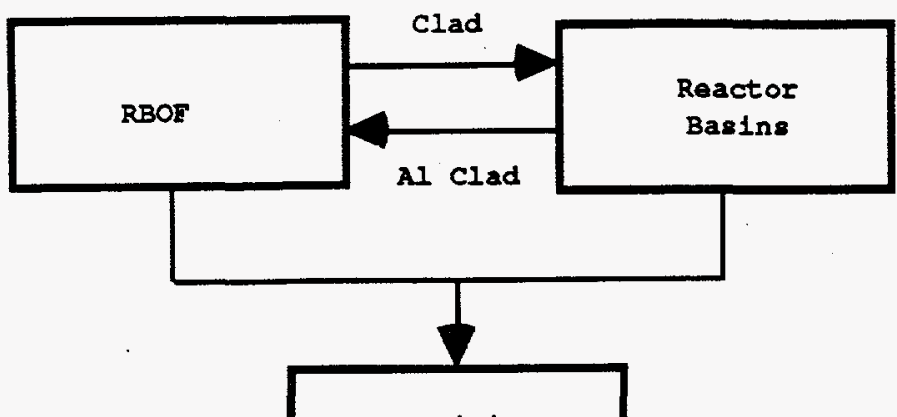

Receiving

Facility

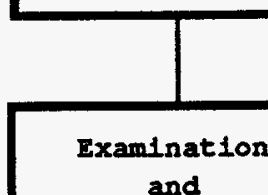

Charaterization

Packaging

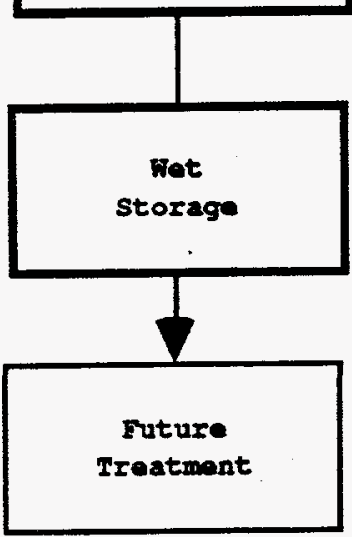

All Spent Fuels from other DOE Sites

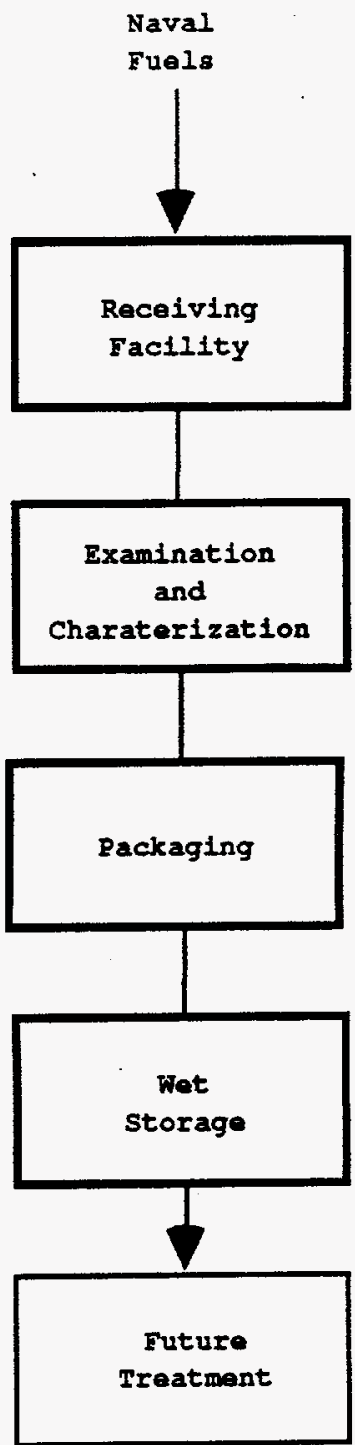


Section 4

Techrical Data summary supporting the INEL spent Fuel eIS

Document No. NMP-PIS-930182, Revision 2

March 22 1924

TABLE 23

PERSONNEI AND COST DATA FOR CASE 5b

\begin{tabular}{|c|c|c|c|c|c|}
\hline YEAR & \multicolumn{2}{|c|}{ PERSONNEL } & \multicolumn{2}{|c|}{$\begin{array}{c}\text { FUNDING } \\
(\$ M 11 \text { IOns) }\end{array}$} & $\begin{array}{l}\text { OTILITY COST } \\
\text { (SMIIIIOns) }\end{array}$ \\
\hline & CAPITAL & ORERATIONS & CAPITAL & OPERATIONS & \\
\hline 1994 & 100 & 4,960 & 10.0 & 374.0 & 28.0 \\
\hline 1995 & 90 & 4,700 & 9.0 & 361.0 & 28.0 \\
\hline 1996 & 80 & 4,270 & 8.0 & 337.0 & 28.0 \\
\hline 1997 & 70 & 3,860 & 7.0 & 312.0 & 23.0 \\
\hline 1998 & 60 & 3,190 & 6.0 & 263.0 & 21.0 \\
\hline 1999 & 60 & 2,630 & 6.0 & 221.0 & 19.0 \\
\hline 2000 & 1,990 & 2,460 & 226.0 & 211.0 & 21.0 \\
\hline 2001 & 3.830 & 2,580 & 446.0 & 226.0 & 22.0 \\
\hline 2002 & 5,430 & 2,820 & 647.0 & 253.0 & 22.0 \\
\hline 2003 & 5,320 & 3,530 & 647.0 & 324.0 & 22.0 \\
\hline 2004 & 5,200 & 4,210 & 647.0 & 376.0 & 22.0 \\
\hline 2005 & 3,360 & 4,250 & 427.0 & 407.0 & 22.0 \\
\hline 2006 & 1.600 & 4,700 & 207.0 & 461.0 & 23.0 \\
\hline 2007 & 120 & 4,680 & 14.0 & 468.0 & 28.0 \\
\hline 2008 & 120 & 4,650 & 14.0 & 476.0 & 28.0 \\
\hline 2009 & 120 & 4,620 & 16.0 & 484.0 & 36.0 \\
\hline 2010 & 120 & 4,600 & 16.0 & 492.0 & 36.0 \\
\hline 2011 & 120 & 4,600 & 16.0 & 503.0 & 36.0 \\
\hline 2012 & 120 & 4,580 & 16.0 & 511.0 & 36.0 \\
\hline 2013 & 120 & 4,580 & 16.0 & 523.0 & 37.0 \\
\hline 2014 & 120 & 4,520 & 16.0 & 528.0 & 37.0 \\
\hline 2015 & 120 & 4,450 & 18.0 & 532.0 & 37.0 \\
\hline 2016 & 120 & 4,450 & 18.0 & 543.0 & 37.0 \\
\hline 2017 & 120 & 4.450 & 18.0 & 555.0 & 38.0 \\
\hline 2018 & 120 & 4,450 & 18.0 & 567.0 & 38.0 \\
\hline 2019 & 120 & 4,450 & 18.0 & 580.0 & 38.0 \\
\hline 2020 & 120 & 4,450 & 20.0 & 593.0 & 38.0 \\
\hline 2021 & 120 & 3,250 & 20.0 & 477.0 & 32.0 \\
\hline 2022 & 120 & 3,250 & 20.0 & 488.0 & 32.0 \\
\hline 2023 & 120 & 3,250 & 20.0 & 499.0 & 32.0 \\
\hline 2024 & 120 & 3,250 & 22.0 & 510.0 & 32.0 \\
\hline 2025 & 120 & 3,800 & 22.0 & 604.0 & 33.0 \\
\hline 2026 & 230 & 3,700 & 47.0 & 602.0 & 33.0 \\
\hline 2027 & 230 & 3,700 & 47.0 & 579.0 & 33.0 \\
\hline 2028 & 230 & 3,700 & 48.0 & 3,700 & 33.0 \\
\hline 2029 & 120 & 3,600 & 24.0 & 594.0 & 34.0 \\
\hline 2030 & 120 & 3,600 & 24.0 & 607.0 & 34.0 \\
\hline 2031 & 120 & 3,600 & 24.0 & 620.0 & 34.0 \\
\hline 2032 & 120 & 3,600 & 26.0 & 628.0 & 34.0 \\
\hline 2033 & 120 & 3,700 & 26.0 & 646.0 & 35.0 \\
\hline 2034 & 120 & 4,000 & 26.0 & 705.0 & 35.0 \\
\hline 2035 & 1,000 & 4,300 & $1,513.0$ & 743.0 & 40.0 \\
\hline
\end{tabular}


Section 4

Technical Data Summary supporting the INEL spent FueI EIS

Document No. NMP-PLS-930182, Revision 2

March 22, 3994

TABLE 24

WASTE AND EMISSIONS DATA FOR CASE 5b

\begin{tabular}{|c|c|c|c|c|c|c|}
\hline YEAR & \multicolumn{5}{|c|}{ WASTE VOLOMES } & EMISSIONS \\
\hline & $\begin{array}{c}\text { CANISTER } \\
\text { (aty.) }\end{array}$ & $\begin{array}{c}\text { SALTCRETE } \\
\text { (cu yds) }\end{array}$ & $\begin{array}{c}\text { LL } \\
(c u f t)\end{array}$ & $\begin{array}{c}\text { SAN I TARY } \\
\text { (Kgal) }\end{array}$ & $\begin{array}{c}\text { TRO } \\
\text { (cu yds) }\end{array}$ & \\
\hline 1994 & 0 & 0 & 45,000 & 60,720 & 57 & slight \\
\hline 1995 & 0 & 0 & 45,000 & 58,920 & 57 & slight \\
\hline 1996 & $16-0$ & $4,839,0$ & $9+100030$ & 58,560 & 65 & slight \\
\hline 1997 & 170 & $4,839-0$ & $9 H 1000^{\circ}$ & 51,000 & 65 & slight \\
\hline 1998 & 170 & 4,8390 & 91,4000 & 46,920 & 65 & slight \\
\hline 1999 & $27 \quad 0$ & 4,8390 & 91,6000 & 38,880 & 65 & slight \\
\hline 2000 & 0 & 0 & 45,000 & 51,120 & 57 & slight \\
\hline 2001 & 0 & 0 & 20,000 & 72,720 & 20 & slight \\
\hline 2002 & 0 & 0 & 20,000 & 94,800 & 20 & slight \\
\hline 2003 & 0 & 0 & 20,000 & 101,880 & 20 & slight \\
\hline 2004 & 0 & 0 & 20,000 & 106,080 & 20 & slight \\
\hline 2005 & 0 & 0 & 20,000 & 88,560 & 20 & slight \\
\hline 2006 & 0 & 0 & 20,000 & 74,520 & 20 & slight \\
\hline 2007 & 0 & 0 & 20,000 & 56,520 & 20 & slight \\
\hline 2008 & 0 & 0 & 20,000 & 56,160 & 20 & slight \\
\hline 2009 & 0 & 0 & 20,000 & 55,920 & 20 & slight \\
\hline 2010 & 0 & 0 & 20,000 & 55,560 & 20 & slight \\
\hline 2011 & 0 & 0 & 20,000 & 55,560 & 20 & slight \\
\hline 2012 & 0 & 0 & 20,000 & 55,200 & 20 & slight \\
\hline 2013 & 0 & 0 & 20,000 & 54,720 & 20 & slight \\
\hline 2014 & 0 & 0 & 20,000 & 53,880 & 20 & slight \\
\hline 2015 & 0 & 0 & 20,000 & 53,880 & 20 & slight \\
\hline 2016 & 0 & 0 & 20,000 & 53,880 & 20 & slight \\
\hline 2017 & 0 & 0 & 20,000 & 53,880 & 20 & slight \\
\hline 2018 & 0 & 0 & 20,000 & 53,880 & 20 & slight \\
\hline 2019 & 0 & 0 & 20,000 & 53,880 & 20 & slight \\
\hline 2020 & 0 & 0 & 20,000 & 53,880 & 20 & slight \\
\hline 2021 & 0 & 0 & 20,000 & 40,440 & 20 & slight \\
\hline 2022 & 0 & 0 & 20,000 & 40,440 & 20 & slight \\
\hline 2023 & 0 & 0 & 20,000 & 40,440 & 20 & slight \\
\hline 2024 & 0 & 0 & 20,000 & 40,440 & 20 & slight \\
\hline 2025 & 0 & 0 & 20,000 & 47,040 & 20 & slight \\
\hline 2026 & 0 & 0 & 20,000 & 47,880 & 20 & slight \\
\hline 2027 & 0 & 0 & 20,000 & 47,880 & 20 & slight \\
\hline 2028 & 29142 & 72445,978 & 104,198 & 47,880 & 60 & slight \\
\hline 2029 & 2342 & 5,978 & 104,198 & 44,640 & 60 & slight \\
\hline 2030 & $29+2$ & 5,978 & 104,198 & 44,640 & 60 & slight \\
\hline 2031 & 2242 & 5,978 & 104,198 & 44,640 & 60 & slight \\
\hline 2032 & 2942 & 5,978 & 104,198 & 44,640 & 60 & slight \\
\hline 2033 & 20.42 & $\sqrt{5,-978}$ & 104,198 & 45,840 & 60 & slight \\
\hline 2034 & 0 & 0 & 20,000 & 49,440 & 20 & slight \\
\hline 2035 & 0 & 0 & 20,000 & 64,800 & 20 & slight \\
\hline
\end{tabular}

42

$\frac{6}{252}$ 


\section{OPTION 5 - CENTRALIZATION}

Case 5c - Provides interim dry storage for the entire DOE spent fuel inventory. SRS will develop the recessary dry storage technology through an R\&D program. Capabilities to monitor, examine, characterize, and package the spent fuels are provided.

ACTIVITY DESCRIPTION:

SRS proceeds with the spent fuel rearrangement plan described in Case 1 to provide acceptable storage conditions to minimize failure of the aluminum clad spent fuels prior to placement in dry storage.

Placement of a variety of spent fuels in a dry storage repository requires an extensive $R \& D$ program, fuel characterization capability, and periodic reexamination including sampling. SRS must design, construct, and operate the dry storage facilities required by this case.

Separate facilities will be built to manage the naval reactor spent fuels due their more stringent storage requirements.

SRS will process the solution inventories and the other materials as required for safety.

The activities required to implement this case are as follows:

FY-94 The DOE will initiate the EIS process to support: (1) temporary storage of spent fuels in one reactor basin and RBOF; (2) interim dry storage of the entire DOE spent fuels inventory; and (3) processing the SRS solution inventory.

SRS will initiate the R\&D program and conceptual studies required to provide the technical basis for dry storage of the entire DOE spent fuel inventory.

FY-95 The DOE will complete the EIS process by issuing a ROD permitting the proposed activities. 
Technical Data Summary supporting the INEL Spent Fuel EIS

Document No. NMP-PIS-930182, Revision 2

March 22. 1994

FY-96 SRS will initiate a Congressional Iine Item project to provide the dry storage facilities.

SRS will embark on an extensive program to renovate a selected reactor basin to improve water quality as required for the rearrangement program.

SRS will start processing the solution inventory stored in the SRS chemical separation facilities.

FY-97 The CDR for the dry facilities project will be completed.

At the completion of the program to renovate the selected reactor basin, SRS will relocate the SST/Zr clad spent fuels in the SRS inventory from RBOF to that reactor basin. As the SST/Zr spent fuels are transferred to the selected reactor basin, these positions in RBOF will be backfilled with $A I$ clad spent fuels from the other two reactor basins.

FY-98 The rearrangement program will be completed.

FY-99 Congress will authorize the new dry storage facilities project.

FY-00 Design and construction activities for the dry wet storage facilities will commence.

EY-03 Preparations for the startup activities will commence.

FY-04 A fully integrated production plan for the new dry storage facilities will start into development in conjunction with a plan for full resumption of spent fuel shipments to SRS.

FY-06 Construction of the new dry storage facilities will be completed. Startup activities will begin.

EY-08 After all the readiness reviews are satisfactorily completed, the dry storage facilities will begin operations. The spent fuel shipment plan will commence. 
Section 4

Technical Data Summary Supporting the INEL spent Fuel EIS Document No. NMP-PLS-930182, Revision 2

March 22, 1294

EY-14 SRS will initiate an R\&D program to develop the final disposition for the spent fuels.

EY-16 Based on the results from the R\&D program, SRS will develop a Congressional Line Item project to provide the facilities necessary for the final disposition.

FY-17 The CDR for the final disposition project will be completed.

FY-20 The dry storage activities will be completed. The facilities will be placed into the S\&M mode which will include some examination, repackaging and monitoring activities.

Congress will authorize the final disposition facility project.

FY-21 Design and construction activities for the final disposition project will begin.

FY-23 Preparations for the startup activities will commence.

FY-25 The construction of the new dry facilities will be completed. Startup activities will begin.

D\&D activities for the excess dry storage facilities will begin.

FY-28 After satisfactory completion of the readiness reviews, the dry facilities will begin operations.

The D\&D activities will be completed.

FY-33 The final disposition treatment will be completed. Flushing and cleanout activities will start.

FY-35 The final disposition facility and the remainder of the wet storage facilities will be placed into a $S \& M$ mode. 
Section 4

Technical Data Sumary Supporting the INII Spent Iuel EIS

Document No. NMP-PLS-930182, Revision 2

March 22, 1924

EACILITIES USED FOR THIS CASE:

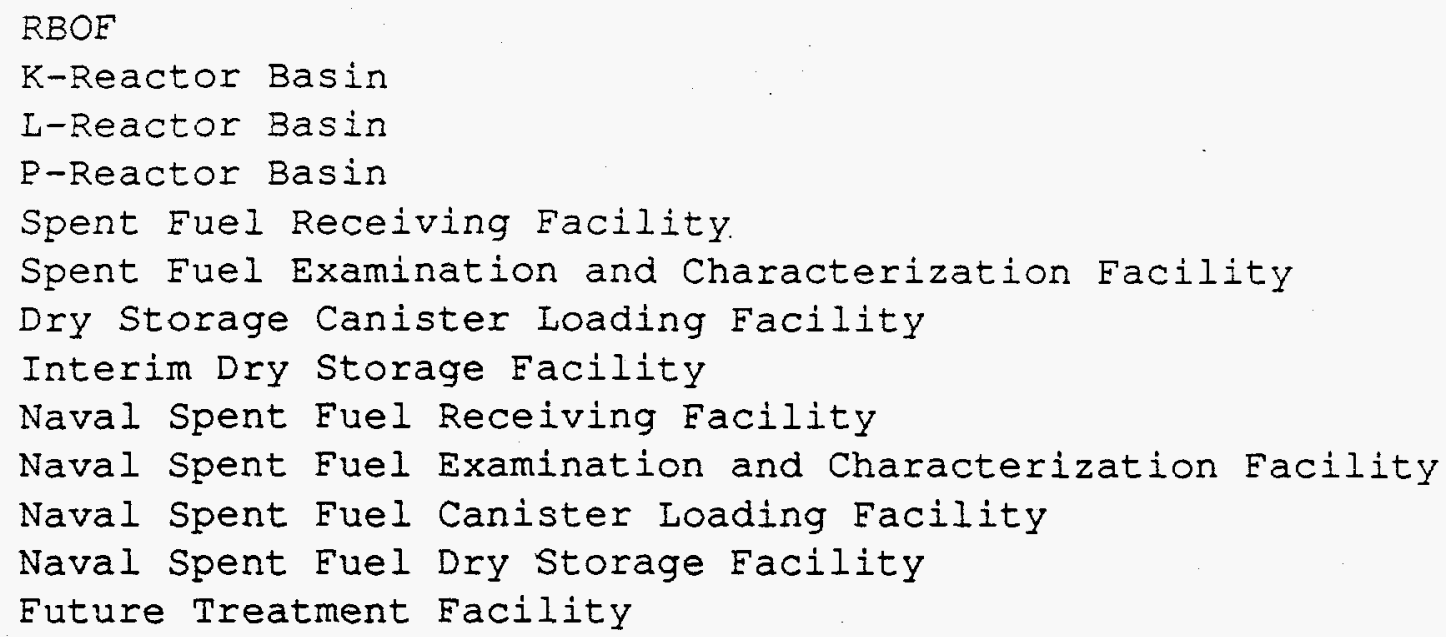

Acceptable resolution of the EIS process which will permit the interim dry storage of the planned spent fuels inventory and processing the SRS solution inventories and other materials as required for safety.

Dry storage of spent fuels is an interim action. No disposition technology exists except some type of future treatment. The encapsulation necessary to prevent failure of the aluminum clad spent fuel cladding through interim dry storage period makes future treatment more complex and costly.

Return of the FRR spent fuels would be significantly delayed.

Massive capital expenditures are required for the design, construction, then the $D \& D$ of the new dry storage facilities.

Massive annual budgets are required to operate the facilities at SRS and the other DQE sites.

Numerous shipments of the spent fuels are required.

The public willingness to store spent fuels without a technically developed disposition is not known at his time. 
Section 4

Technical Data summary Supporting the INIL Spent Fuel EIS

Document No. NMP-PLS-930182, Revision 2

March $22, \quad 1994$

\section{FIGURE 14}

FLOW CHART FOR CASE 5C

SRS Inventory

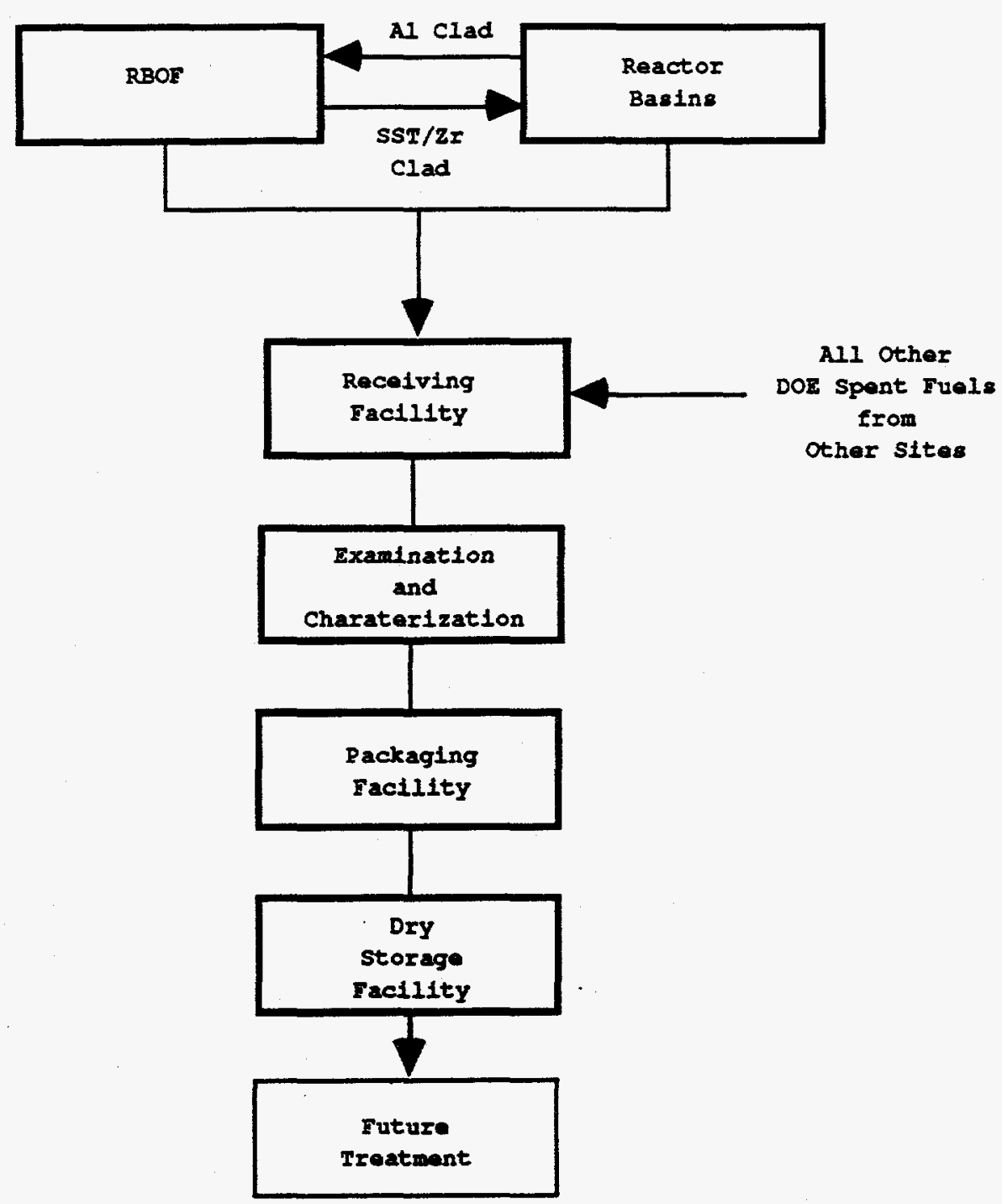

Naval

Fuels

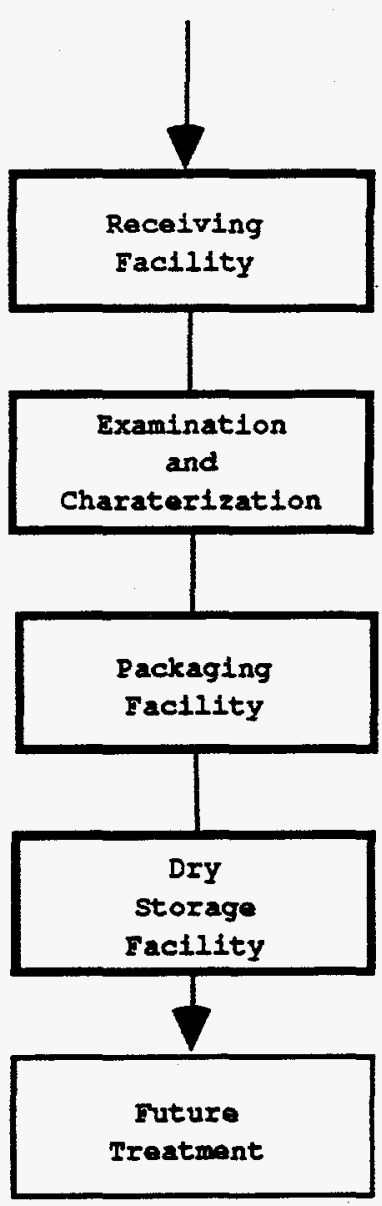


Section 4

Technlcal Data Summary Supporting the INEL Spent Fuel EIS

Document No. NMP-RLS-930182, Revision 2

March 22, 1924

TABLE 25

PERSONNEL AND COST DATA FOR CASE 5C

\begin{tabular}{|c|c|c|c|c|c|}
\hline \multirow[t]{2}{*}{ YEAR } & \multicolumn{2}{|c|}{ PERSONNEI } & \multicolumn{2}{|c|}{$\begin{array}{c}\text { FONDING } \\
(\$ M i 11 \text { SOns) } \\
\end{array}$} & \multirow[t]{2}{*}{$\begin{array}{l}\text { OTIIITY COST } \\
\text { (\$MIIIIOn8) }\end{array}$} \\
\hline & CAPITAL & ORERATIONS & CAPITAI & OPERATIONS & \\
\hline 1994 & 100 & 4,960 & 10.0 & 374.0 & 28.0 \\
\hline 1995 & 90 & 4,700 & 9.0 & 361.0 & 28.0 \\
\hline 1996 & 80 & 4,270 & 8.0 & 337.0 & 28.0 \\
\hline 1997 & 70 & 3,850 & 7.0 & 312.0 & 23.0 \\
\hline 1998 & 60 & 3,180 & 6.0 & 263.0 & 21.0 \\
\hline 1999 & 60 & 2,620 & 6.0 & 220.0 & 19.0 \\
\hline 2000 & 1,810 & 2,450 & 206.0 & 211.0 & 21.0 \\
\hline 2001 & 3,490 & 2,570 & 406.0 & 226.0 & 22.0 \\
\hline 2002 & 5,100 & 2,800 & 607.0 & 251.0 & 22.0 \\
\hline 2003 & 4,990 & 3,490 & 607.0 & 320.0 & 22.0 \\
\hline 2004 & 4.880 & 3,950 & 607.0 & 370.0 & 22.0 \\
\hline 2005 & 3,200 & 4,180 & 407.0 & 401.0 & 22.0 \\
\hline 2006 & 1,600 & 4,610 & 207.0 & 452.0 & 23.0 \\
\hline 2007 & 120 & 4,590 & 14.0 & 460.0 & 28.0 \\
\hline 2008 & 120 & 4,560 & 14.0 & 467.0 & 28.0 \\
\hline 2009 & 120 & 4,540 & 16.0 & 475.0 & 36.0 \\
\hline 2010 & 120 & 4,510 & 16.0 & 483.0 & 36.0 \\
\hline 2011 & 120 & 4,510 & 16.0 & 493.0 & 36.0 \\
\hline 2012 & 120 & 4,480 & 16.0 & 502.0 & 36.0 \\
\hline 2013 & 120 & 4,480 & 16.0 & 513.0 & 37.0 \\
\hline 2014 & 120 & 4,440 & 16.0 & 518.0 & 37.0 \\
\hline 2015 & 120 & 4,370 & 18.0 & 522.0 & 37.0 \\
\hline 2016 & 120 & 4,370 & 18.0 & 533.0 & 37.0 \\
\hline 2017 & 120 & 4,370 & 18.0 & 545.0 & 38.0 \\
\hline 2018 & 120 & 4,370 & 18.0 & 557.0 & 38.0 \\
\hline 2019 & 120 & 4,370 & 18.0 & 569.0 & 38.0 \\
\hline 2020 & 120 & 4,370 & 20.0 & 582.0 & 38.0 \\
\hline 2021 & 120 & 3,250 & 20.0 & 477.0 & 32.0 \\
\hline 2022 & 120 & 3,250 & 20.0 & 488.0 & 32.0 \\
\hline 2023 & 120 & 3,250 & 20.0 & 499.0 & 32.0 \\
\hline 2024 & 120 & 3,250 & 22.0 & 510.0 & 32.0 \\
\hline 2025 & 120 & 3,800 & 22.0 & 604.0 & 33.0 \\
\hline 2026 & 290 & 3,700 & 47.0 & 602.0 & 33.0 \\
\hline 2027 & 290 & 3,700 & 47.0 & 579.0 & 33.0 \\
\hline 2028 & 290 & 3,700 & 48.0 & 592.0 & 33.0 \\
\hline 2029 & 120 & 3,600 & 24.0 & 594.0 & 34.0 \\
\hline 2030 & 120 & 3,600 & 24.0 & 607.0 & 34.0 \\
\hline 2031 & 120 & 3,600 & 24.0 & 620.0 & 34.0 \\
\hline 2032 & 120 & 3,600 & 26.0 & 628.0 & 34.0 \\
\hline 2033 & 120 & 3,700 & 26.0 & 646.0 & 35.0 \\
\hline 2034 & 120 & 4,000 & 26.0 & 705.0 & 35.0 \\
\hline 2035 & 1,000 & 4,300 & $1,513.0$ & 743.0 & 40.0 \\
\hline
\end{tabular}


Section

Technical Data Summary supporting the INEL spent Fuel EIS

Document No, NMP-PIS-930182, Revision 2

Narch 22, 1924

TABLE 26

WASTE AND EMISSIONS DATA FOR CASE 5C

\begin{tabular}{|c|c|c|c|c|c|c|}
\hline YEAR & \multicolumn{5}{|c|}{ WASTE VOLOMES } & EMISSIONS \\
\hline & $\begin{array}{c}\text { CANISTIR } \\
\text { (qty.) }\end{array}$ & $\begin{array}{c}\text { SALTCRETE } \\
\text { (cu yds) }\end{array}$ & $\begin{array}{c}I I \\
(c u f t)\end{array}$ & $\begin{array}{c}\text { SANITARY } \\
\text { (Kgal) }\end{array}$ & $\begin{array}{c}\text { TRO } \\
\text { (cu yds) }\end{array}$ & \\
\hline 1994 & 0 & 0 & 45,000 & 60,720 & 57 & Slight \\
\hline 1995 & 0 & 0 & 45,000 & 57,480 & 57 & Slight \\
\hline 1996 & 0 & 0 & 45,000 & 52,200 & 20 & Slight \\
\hline 1997 & 0 & 0 & 20,000 & 47,040 & 20 & SIight \\
\hline 1998 & 0 & 0 & 20,000 & 38,880 & 20 & Slight \\
\hline 1999 & 0 & 0 & 20,000 & 32,160 & 20 & Slight \\
\hline 2000 & 0 & 0 & 20,000 & 51,120 & 20 & Slight \\
\hline 2001 & 0 & 0 & 20,000 & 72,720 & 20 & Slight \\
\hline 2002 & 0 & 0 & 20,000 & 94,800 & 20 & Slight \\
\hline 2003 & 0 & 0 & 20,000 & 101,760 & 20 & Slight \\
\hline 2004 & 0 & 0 & 20,000 & 105,960 & 20 & Slight \\
\hline 2005 & 0 & 0 & 20,000 & 88,560 . & 20 & Slight \\
\hline 2006 & 0 & 0 & 20,000 & 74,520 & 20 & Slight \\
\hline 2007 & 0 & 0 & 20,000 & 56,520 & 20 & slight \\
\hline 2008 & 0 & 0 & 20,000 & 56,160 & 20 & Slight \\
\hline 2009 & 0 & 0 & 20,000 & 55,920 & 20 & Slight \\
\hline 2010 & 0 & 0 & 20,000 & 55,560 & 20 & Slight \\
\hline 2011 & 0 & 0 & 20,000 & 55,560 & 20 & Slight \\
\hline 2012 & 0 & 0 & 20,000 & 55,200 & 20 & Slight \\
\hline 2013 & 0 & 0 & 20,000 & $55,200$. & 20 & Slight \\
\hline 2014 & 0 & 0 & 20,000 & 54,720 & 20 & Slight \\
\hline 2015 & 0 & 0 & 20,000 & 53,880 & 20 & Slight \\
\hline 2016 & 0 & 0 & 20,000 & 53,880 & 20 & Slight \\
\hline 2017 & 0 & 0 & 20,000 & 53,880 & 20 & Slight \\
\hline 2018 & 0 & 0 & 20,000 & 53,880 & 20 & Slight \\
\hline 2019 & 0 & 0 & 20,000 & 53,880 & 20 & Slight \\
\hline 2020 & 0 & 0 & 20,000 & 53,880 & 20 & slight \\
\hline 2021 & 0 & 0 & 20,000 & 40,440 & 20 & slight \\
\hline 2022 & 0 & 0 & 20,000 & 40,440 & 20 & slight \\
\hline 2023 & 0 & 0 & 20,000 & 40,440 & 20 & Slight \\
\hline 2024 & 0 & 0 & 20,000 & 40,440 & 20 & Slight \\
\hline 2025 & 0 & 0 & 20,000 & 47,040 & 20. & Slight \\
\hline 2026 & 0 & 0 & 20,000 & 47,880 & 20 & slight \\
\hline 2027 & 0 & 0 & 20,000 & 47,880 & 20 & Slight \\
\hline 2028 & 42 & 9,849 & 176,998 & 47,880 & 85 & Slight \\
\hline 2029 & 42 & 9,849 & 176,998 & 44,640 & 85 & slight \\
\hline 2030 & 42 & 9,849 & 176,998 & 44,640 & 85 & Slight \\
\hline 2031 & 42 & 9,849 & 176,998 & 44,640 & 85 & Slight \\
\hline 2032 & 42 & 9,849 & 176,998 & 44,640 & 85 & Slight \\
\hline 2033 & 42 & 9,849 & 176,998 & 45,840 & 85 & slight \\
\hline 2034 & 0 & 0 & 20,000 & 49,440 & 20 & slight \\
\hline 2035 & 0 & 0 & 20,000 & 63,600 & 20 & Slight \\
\hline
\end{tabular}




\section{Option 5 - CENTRALIZATION}

Case 5d - Centralization at another site is accomplished by shipment of all SRS spent fuels to the selected site for disposition.

ACTIVITY DESCRIPTION :

In this case, the entire SRS spent fuel inventory would be shipped to a designated central site. A shipping plan will be formulated which will shutdown the reactor basins as quickly as possible. Where possible, the spent fuels in the reactor basins will be shipped directly to the central site. When necessary, the spent fuels will be transferred to RBOF, then shipped. The spent fuels must characterized prior to shipment.

Before any shipments can begin, details of the shipment process will be resolved with the Department of Transportation, the central site and other regulatory bodies. Shipment of these fuels will likely require an EIS by the central site.

SRS will process the solution inventories and the other materials as required for safety.

The activities required by this case are as follows:

FY-94 The DOE will initiate the EIS process to support: (1) shipment of the SRS spent fuels to the designated central disposition site and (2) processing the solution inventories.

SRS will begin the conceptual studies necessary to ship the SRS spent fuels to the designated central disposition site.

FY-95 The DOE will complete the EIS process by issuing the ROD permitting the proposed activities.

FY-96 SRS will initiate the Congressional Line Item project to construct a characterization. facility.

SRS will begin processing the solution inventories.

FY-97 The CDR for the characterization facility project will be completed.

The solution inventories processing will be completed. The flushing and cleanout activities for the separation facilities will commence. 
FY-99 Congress will authorize the characterization facility project.

EY-00 The design and construction activities for the characterization facility project will begin.

The separation facilities will be placed into a S\&M mode.

FY-02 Preparations for the startup activities will commence.

FY-04 Construction of the characterization facility will be completed. Startup activities will begin.

EY-06 After all readiness reviews are satisfactorily completed, the characterization façility will start operations.

Actual shipments will start.

FY-10 The last shipment will be completed.

Flushing and cleanout activities will commence.

FY-12 RBOF and the reactor basins will be placed into a $S \& M$ mode.

FY-15. D\&D of the characterization facility starts.

FY-18 D\&D of the characterization facility is complete.

EACILITIES USED IN THIS CASE:

RBOF

K-Reactor Basin

L-Reactor Basin

P-Reactor Basin

Characterization Facility

Rail/ Trucking Transportation System 
Technical Data Summary Supporting the INEL spent Fuel IIS Document No. MMP-2IS-930182, Revision 2

\section{OPEN ISSUES :}

Acceptable resolution of the EIS process which will permit the shipment of the SRS spent fuel inventory to the disposition site.

Numerous shipments of spent fuels are required.

The public willingness to store spent fuels without a technically developed disposition is not known at his time.

Development of certified shipping containers for the various SRS spent fuels may be required. 
Section 4

Technicai Data summary supporting the INEL spent Fuel eIs

Document No. NMP-PLS-930182, Revision 2

March $22 \quad 2924$

\section{FIGURE 15}

FIOW CHART FOR CASE 5d

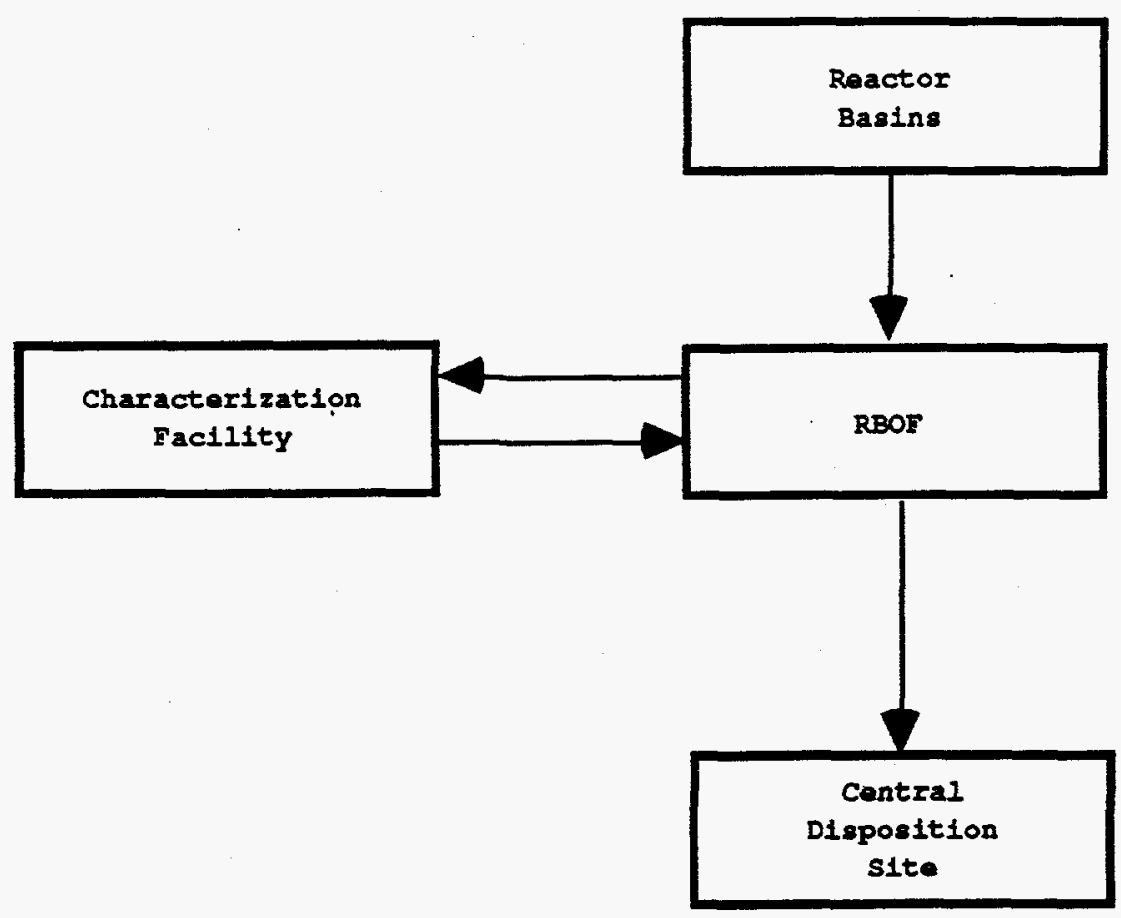


section 4

Technical Data Summary supporting the INEL spent Fuel EIS

Document No. NMP-PLS-930182, Revision 2

March 22, 1924

TABLE 27

PERSONNEL AND COST DATA FOR CASE 5d

\begin{tabular}{|c|c|c|c|c|c|}
\hline \multirow[t]{2}{*}{ YEAR } & \multicolumn{2}{|c|}{ PERSONNEL } & \multicolumn{2}{|c|}{$\begin{array}{c}\text { FDNDING } \\
(\$ M 111 \text { 10ns })\end{array}$} & \multirow[t]{2}{*}{$\begin{array}{l}\text { OTIIITY COST } \\
\text { (SMIIIIONS) }\end{array}$} \\
\hline & CAPITAL & OPERATIONS & CAPITAL & OPERATIONS & \\
\hline 1994 & 100 & 4,960 & 10.0 & 374.0 & 28.0 \\
\hline 1995 & 90 & 4,700 & 9.0 & 361.0 & 28.0 \\
\hline 1996 & 80 & 4,180 & 8.0 & 330.0 & 28.0 \\
\hline 1997 & 70 & 3,930 & 7.0 & 317.0 & 21.0 \\
\hline 1998 & 60 & 3,320 & 6.0 & 273.0 & 21.0 \\
\hline 1999 & 60 & 2,940 & 6.0 & 246.0 & 19.0 \\
\hline 2000 & 140 & 2,770 & 16.0 & 238.0 & 18.0 \\
\hline 2001 & 270 & 2,760 & 31.0 & 243.0 & 18.0 \\
\hline 2002 & 350 & 2,740 & 42.0 & 247.0 & 18.0 \\
\hline 2003 & 220 & 2,720 & 27.0 & 251.0 & 18.0 \\
\hline 2004 & 140 & 2,790 & 17.0 & 262.0 & 18.0 \\
\hline 2005 & 60 & 2,790 & 7.0 & 268.0 & 19.0 \\
\hline 2006 & 60 & 2,790 & 7.0 & 274.0 & 19.0 \\
\hline 2007 & 60 & 2,790 & 7.0 & 280.0 & 19.0 \\
\hline 2008 & 60 & 2,790 & 7.0 & 286.0 & 19.0 \\
\hline 2009 & 60 & 2,790 & 7.0 & 292.0 & 20.0 \\
\hline 2010 & 60 & 2,790 & 8.0 & 299.0 & 20.0 \\
\hline 2011 & 60 & 2,640 & 8.0 & 289.0 & 20.0 \\
\hline 2012 & 60 & 2,640 & 8.0 & 295.0 & 20.0 \\
\hline 2013 & 60 & 2,640 & 8.0 & 302.0 & 20.0 \\
\hline 2014 & 60 & 2.640 & 8.0 & 308.0 & 21.0 \\
\hline 2015 & 60 & 2,640 & 22.0 & 315.0 & 21.0 \\
\hline 2016 & 60 & 2,640 & 23.0 & 322.0 & 21.0 \\
\hline 2017 & 60 & 2,640 & 23.0 & 329.0 & 21.0 \\
\hline 2018 & 60 & 2,630 & 9.0 & 336.0 & 22.0 \\
\hline 2019 & 60 & 2,630 & 9.0 & 344.0 & 22.0 \\
\hline 2020 & 60 & 2,640 & 10.0 & 351.0 & 22.0 \\
\hline 2021 & 60 & 2,640 & 10.0 & 359.0 & 22.0 \\
\hline 2022 & 60 & 2,630 & 10.0 & 367.0 & 23.0 \\
\hline 2023 & 60 & 2,640 & 10.0 & 375.0 & 23.0 \\
\hline 2024 & 60 & 2.640 & 11.0 & 383.0 & 23.0 \\
\hline 2025 & 60 & 2,640 & 11.0 & 392.0 & 23.0 \\
\hline 2026 & 60 & 2.640 & 11.0 & 400.0 & 23.0 \\
\hline 2027 & 60 & 2,640 & 11.0 & 409.0 & 24.0 \\
\hline 2028 & 60 & 2,640 & 12.0 & 418.0 & 24.0 \\
\hline 2029 & 60 & 2.640 & 12.0 & 427.0 & 24.0 \\
\hline 2030 & 60 & 2,640 & 12.0 & 437.0 & 24.0 \\
\hline 2031 & 60 & 2.640 & 12.0 & 446.0 & 25.0 \\
\hline 2032 & 60 & 2,640 & 13.0 & 456.0 & 25.0 \\
\hline 2033 & 60 & 2,640 & 13.0 & 466.0 & 25.0 \\
\hline 2034 & 60 & 2,640 & 13.0 & 476.0 & 25.0 \\
\hline 2035 & 60 & 2,640 & 13.0 & 487.0 & 25.0 \\
\hline
\end{tabular}


Section 4

Technical Data summary supporting the INEL spent ruel EIS

Document No. MMP-PLS-930182, Revision 2

Nareh $22, \quad 1994$

TABLE 28

WASTE AND EMISSIONS DATA FOR CASE 5d

\begin{tabular}{|c|c|c|c|c|c|c|}
\hline \multirow[t]{2}{*}{ YEAR } & \multicolumn{5}{|c|}{ WASTE VOLUMES } & \multirow[t]{2}{*}{ EMISSIONS } \\
\hline & $\begin{array}{c}\text { CANISTER } \\
\text { (qty.) }\end{array}$ & $\begin{array}{c}\text { SALTCRETE } \\
\text { (cuyds) }\end{array}$ & $\begin{array}{c}\mathrm{LI} \\
\text { (cu } f t)\end{array}$ & $\begin{array}{c}\text { SARITARY } \\
\text { (Kgal) }\end{array}$ & $\begin{array}{c}\text { TRQ } \\
\text { (cu yds) }\end{array}$ & \\
\hline 1994 & 0 & 0 & 45,000 & 60,720 & 57 & slight \\
\hline 1995 & 0 & 0 & 45,000 & 57,480 & 57 & slight \\
\hline 1996 & 0 & 0 & 45,000 & 51,120 & 20 & slight \\
\hline 1997 & 0 & 0 & 20,000 & 48,000 & 20 & slight \\
\hline 1998 & 0 & 0 & 20,000 & 40,560 & 20 & slight \\
\hline 1999 & 0 & 0 & 20,000 & 36,000 & 20 & slight \\
\hline 2000 & 0 & 0 & 20,000 & 34,920 & 20 & slight \\
\hline 2001 & 0 & 0 & 20,000 & 36,360 & 20 & slight \\
\hline 2002 & 0 & 0 & 20,000 & 37,080 & 20 & slight \\
\hline 2003 & 0 & 0 & 20,000 & 35,280 & 20 & slight \\
\hline 2004 & 0 & 0 & 20,000 & 35,160 & 20 & slight \\
\hline 2005 & 0 & 0 & 20,000 & 34,200 & 20 & slight \\
\hline 2006 & 0 & 0 & 20,000 & 34,200 & 20 & slight \\
\hline 2007 & 0 & 0 & 20,000 & 34,200 & 20 & slight \\
\hline 2008 & 0 & 0 & 20,000 & 34,200 & 20 & 0 \\
\hline 2009 & 0 & 0 & 20,000 & 34,200 & 20 & 0 \\
\hline 2010 & 0 & 0 & 20,000 & 34,200 & 20 & 0 \\
\hline 2011 & 0 & 0 & 20,000 & 32,400 & 20 & 0 \\
\hline 2012 & 0 & 0 & 20,000 & 32,400 & 20 & 0 \\
\hline 2013 & 0 & 0 & 20,000 & 32,400 & 20 & 0 \\
\hline 2014 & 0 & 0 & 20,000 & 32,400 & 20 & 0 \\
\hline 2015 & 0 & 0 & 20,000 & 32,400 & 20 & 0 \\
\hline 2016 & 0 & 0 & 20,000 & 32,400 & 20 & 0 \\
\hline 2017 & 0 & 0 & 20,000 & 32,400 & 20 & 0 \\
\hline 2018 & 0 & 0 & 20,000 & 32,280 & 20 & 0 \\
\hline 2019 & 0 & 0 & 20,000 & 32,280 & 20 & 0 \\
\hline 2020 & 0 & 0 & 20,000 & 32,400 & 20 & 0 \\
\hline 2021 & 0 & 0 & 20,000 & 32,400 & 20 & 0 \\
\hline 2022 & 0 & 0 & 20,000 & 32,280 & 20 & 0 \\
\hline 2023 & 0 & 0 & 20,000 & 32,400 & 20 & 0 \\
\hline 2024 & 0 & 0 & 20,000 & 32,400 & 20 & 0 \\
\hline 2025 & 0 & 0 & 20,000 & 32,400 & 20 & 0 \\
\hline 2026 & 0 & 0 & 20,000 & 32,400 & 20 & 0 \\
\hline 2027 & 0 & 0 & 20,000 & 32,400 & 20 & 0 \\
\hline 2028 & $\$ 20$ & $2,849,0$ & 29976,990 & 32,400 & $20 \quad 85$ & 0 \\
\hline 2029 & 420 & $2,849,0$ & 176,998 & 32,400 & 85 & 0 \\
\hline 2030 & 420 & $9,849,0$ & $176,998-$ & 32,400 & 85 & 0 \\
\hline 2031 & 420 & 2,0450 & 176,998 & 32,400 & 85 & 0 \\
\hline 2032 & 420 & 2842 0 & 176,990 & 32,400 & 85 & 0 \\
\hline 2033 & 420 & 28490 & $\sqrt{176,998}$ & 32,400 & $\sqrt{85}$ & 0 \\
\hline 2034 & 0 & 0 & 20,000 & 32,400 & 20 & 0 \\
\hline 2035 & 0 & 0 & 20,000 & 32,400 & 20 & 0 \\
\hline
\end{tabular}


Section 5

Technical Data Summary Supporting the INEL Spent Fuel EIS
Document No. NMP-PLS-930182, Revision 2

March 22 1224

\section{SECTION 5}

\section{MODULE DATA}


Section 5

Page 113 of 170

Technical Data sumary supporting tho INEL Spent ruel EIS

Document No. NMP-PLS-930182, Revision 2

March $22, \quad 1294$

Module A: Spent Fuel Receiving, Cask Handling and Fuel unloading Facility

EACILITY DESCRIPTION:

The fuel receiving, cask handling and fuel unloading facilities will be part of structure that houses the other facilities required for the related spent fuel handling activities. Shipping casks containing spent fuels mounted on a transport vehicle will be delivered to the fuel receiving facility by either truck or railcar. A roadway and railway to the fuel receiving facility shall be provided from existing site systems.

After a radiation survey, the shipping cask is transferred by the cask crane to a cask decontamination pit for decontamination as necessary. The cask gas temperature in then sampled to determine the need for cooldown. When these procedures are satisfied, the cask-lid bolts are loosened and/or removed prior to being transferred to a receiving pool by the cask crane.

The cask is lowered into the bottom of the receiving basin where the cask lid removed. The spent fuels are inspected to verify against the shipping manifest, transferred to receiving pool if deemed acceptable. The unloaded shipping cask will be removed from the cask basin, decontaminated and returned to the shipper. The spent fuels will be held in the receiving pool for further processing.

INTERFACE WITH EXISTING FACILITY:

The existing Receiving Basin For Offsite Fuels (RBOF) which has been in use since the 1960's is approaching of its design life. nor does it meet all the requirements of a modern storage pool. It is assumed that sometime in the near future, due to design life, regulatory requirements, and capacity considerations; a new storage facility that meets all current standards will be built to accommodate an increased rate of spent fuel receipts and increased storage capacity demand.

DATA :

Facility Size/ Construction: $\quad$ 11,500 ft. ${ }^{2}$ - concrete $\sim 5,040 \mathrm{ft} .^{2}$ - steel frame

Critical Design/Safety Eeatures: DOE Order 6430.1A 
Saction 5

Tachnical Data Summary supporting the INEL Spent Fuel EIS

Document No. NMP-PLS-930182, Revision 2

March 22, 1924

Land Area:

Land Area Disturbed by Construction:

Capacity:

Capital Cost:

Annual Operating Cost:

Life Cycle Cost:

Construction Personnel:

Operations Personnel:

Chemical Inventory:

Nitric Acid

Phosphoric Acid

Oxalic Acid

Sodium Hydroxide

Sodium Dichromate

Betz Slimicide

Sodium Hypochloride

Carbon Dioxide

Polyphosphate

Cleaning solvent

Corrosion inhibitor

Nitrogen
1.7 acres

2.0 acres

3,000 MTE equivalent elements/yr

$\$ 120.0 \mathrm{M}$

$\$ 15.0 \mathrm{M}$

$\$ 810.0 \mathrm{M}$

100 peak

150

500 gal

$500 \mathrm{gal}$

200 gal

500 lbs.

500 lbs.

25 Ibs./yr

20 lbs./yr

$1,000 \mathrm{lbs} . / \mathrm{yr}$

20 lbs./yr

20 lbs./Yr

20 lbs./Yr

2,000 liters

Utility Requirements:

Electricity

Steam

De-ionized water

Cooling water

Domestic water
$5,000 \mathrm{MWH}$

$5,000,000$ lbs. $5,000,000$ gals. 800,000 gals. $1,500,000$ gals.

Waste:

Canister/MTU

Saltstone (CY/YR)

TRU Waste (CY/YR)

10

LI Waste (CY/YR)

150

Sanitary (GAL/YR)

$1,500,000$ 
Section 5

Technical Data Summary Supporting the INEL Spent Fuel EIS
Document No. NMP-PLS-930182, Revision 2

March 22, 1294

AIRBORNE AND LIQUID EMISSIONS BY RELEASE POINTS

The facility exhaust air stream(s) will be routed through HEPA filters, then it will be monitored before it exits the stack.

VOC

Carbon Monoxide

Total suspended particulate

Oxides of Nitrogen

Sulfur Dioxide

Carbon Dioxide
5001 ibs.

1,000 lbs.

300 lbs.

5,000 lbs.

300 lbs.

$3,0001 \mathrm{bs}$.

OPEN ISSUES :

Worker exposure design base dose limit per DOE $N 5480.6$ is less than 500 mrem per year with ALARA considerations incorporated into the design. 


\section{Module B: . Examination and Characterination Facility}

\section{FACILITY DESCRIPTION:}

Spent fuels in the DOE inventory constitute more than 100 individual types based on cladding materials, physical size, chemical form, potential hazardous constituents, burn-up, enrichment, and other factors. Characterization is required for final repository since a significant amount of the spent fuels have been in storage for many years, therefore documentation of these spent fuels may not meet current requirements. Requirements to characterize spent fuels are contained in a draft of DOE Order $5480.2 B$.

Minimum characterization requirements include:

- Euel information/identification including reactor operation and fuel manufacture specification.

- Chemical composition of the spent fuel cladding, structural component mass, fissile material mass and isotopic distribution.

- Radionuclide inventory

- Heat generation

- Nuclear criticality

- Mechanical properties

- Quality Assurance

The spent fuel examination and characterization facility will be located in the same structure with the other facilities required to complete the spent fuel handling activities. It will be a shielded dry cell where fuel is transferred from the receiving pool for a thorough examination, non-destructive assay and other analysis as required. Equipment in the characterization cell will be operated remotely to provide temperature scanning, gamma scanning, chemical composition analysis, weight, and other analytical tests as required.

\section{INTERFACE WITH EXISTING FACILITIES:}

None 
Section 5

Technical Data Summary Supporting the. INEI Spent Fuel EIS Document No. NMP-PLS-930182, Revision 2

March 22, 1924

DATA :

Facility Size and Construction: Concrete - 4,200 ft ${ }^{2}$

Steel frame - 1,800 $\mathrm{ft}^{2}$

Critical Design/Safety Features: DOE Order 6430.1A

Worker exposure $>500^{\circ} \mathrm{mrem} / \mathrm{yr}$

Land Area:

0.6 acres

Land Area Disturbed by Construction: 1.0 acres

Capacity:

3,000 MTE equivalent elements/yr

Capital cost: $\$ 50.0 \mathrm{M}$

Annual Processing Cost:

$\$ 7.0 \mathrm{M}$

Life Cycle Cost:

$\$ 240.0 \mathrm{M}$

Construction Personnel:

40 peak

Operations Personnel:

40

Chemical Inventory:

Betz Slimicide

Sodium Hypochloride

Sodium Hydroxide

Carbon Dioxide

Polyphosphate

Cleaning solvent

Corrosion inhibitor

Nitrogen

Utility Requirements:

Electricity

Steam

De-ionized water

Cooling water.

Domestic water

Waste:

Canister/MTU

Saltstone (CY/YR)

TRU Waste (CY/YR)

LI Waste (CY/YR)

Sanitary (GAL/YR)
$25 \mathrm{lbs} . / \mathrm{yr}$

$20 \mathrm{lbs} . / \mathrm{Yr}$

20 Ibs./Yr

$2,000 \mathrm{lbs} . / \mathrm{Yr}$

20 lbs./yr

$20 \mathrm{lbs} . / \mathrm{Yr}$

20 lbs./yr

1,000 liters

$$
\begin{array}{r}
10,000 \mathrm{MWH} \\
800,000 \mathrm{lbs} \\
10^{6} \mathrm{gal} \\
800,000 \mathrm{gal} \\
800,000 \mathrm{gal}
\end{array}
$$


Section 5

Technical Data Summary supporting the INEI spent ruel EIS

Document No. NMP-PLS-930182, Ravision 2

March 22. 2994

AIRBORNE AND LIQUID EMISSIONS BY RELEASE POINTS:

Fàcility exhausts through HEPA filters and stack is monitored.

VOC

Carbon monoxide

Total suspended particulate

Oxides of Nitrogen

Sulfur Dioxide

Carbon Dioxide
100 lbs.

500 lbs.

100 lbs.

$1,000 \mathrm{lbs}$.

100 lbs.

$1,000 \mathrm{lbs}$.

OPEN ISSUES:

Worker exposure design base dose limit per DOE N 5480.6 is less than 500 mrem per year with ALARA considerations incorporated. 
Module C: Naval Reactor Spent Fuel Examination and characterization Facility

\section{EACILITY DESCRIPTION:}

The naval reactor spent fuels mission must have separate facilities from the other DOE spent fuels due to the more stringent storage requirements. The facilities are assumed to be similar in design to the Expanded Core Facility and the ICPP 666 Building at the INEL site. The facility may be incorporated into the same structure as the other facilities required for the naval reactor spent fuel handling activities.

The spent fuels in shipping casks are first brought into receiving facility (as presently done in Idaho), then transferred into the receiving pool. The spent fuels removed from the receiving pool for examination, characterization, and removal of certain subassemblies which are compressed into a HLW form. After. characterization, the spent fuels are loaded into a storage cask, then transferred to the storage facility. An area in the receiving facility is provided to decontaminate the shipping and transfer casks.

INTEREACE WITH EXISTING FACILITIES:

None

DATA:

Facility Size and Construction: Concrete and steel

Critical Design/Safety Features: DOE Order $6430.1 \mathrm{~A}$

Worker exposure $<500 \mathrm{mrem} /$ year.

Land Area: $\quad 8.0$ acres

Land Area Disturbed by Construction: 10.0 acres

Capacity: Classified

Capital Cost:

$\$ 2,000 \mathrm{M}(800)$

Annual Operating Cost $\$ 40.0 \mathrm{M}$

Life Cycle cost: $\$ 3,945.0 \mathrm{M}$

Construction Personnel:

200 peak

Operations Personnel:

$$
\begin{aligned}
& 500 \text { (doloole facil ity) } \\
\sim & 300 \text { (IN ECF) }
\end{aligned}
$$


Technical Data summary Supporting the INEL spent Fuel EIS Document No. MMP-PIS-930182, Revision 2

March 22. 1924

Chemical Inventory:
Nitric Acid
Phosphoric Acid
Oxalic Acid
Sodium Hydroxide
Sodium Dichromate
Betz Slimicide
Sodium Hypochloride
Carbon Dioxide
Polyphosphate
Cleaning solvent
Corrosion inhibitor
Nitrogen

Utility Requirements:
Electricity
Steam
Domestic water
De-ionized water
Cooling water
Domestic water

Waste:

Canister/MTU

Saltstone (CY/YR)

TRU Waste (CY/YR)

LL Waste (CY/YR)

Sanitary (GAL/YR)

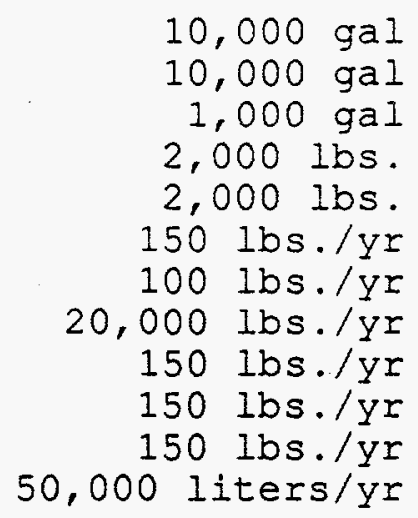

$20,000 \mathrm{MWH}$ $10^{8} \mathrm{lbs}$.

$10^{7} \mathrm{gal}$

$5 \times 10^{7} \mathrm{gal}$

$10^{8} \mathrm{gal}$

$5 \times 10^{6} \mathrm{gal}$

\section{AIRBORNE AND LIQUID EMISSIONS BY RELEASE POINTS;}

Eacility exhaust air streams will be routed through HEPA filters, then through a stack where it is monitored.

$\begin{array}{lrl}\text { Voc } & 8,000 \text { lbs. } \\ \text { Carbon Monoxide } & 50,000 \text { lbs. } \\ \text { Total suspended particulate } & 3,000 \text { lbs. } \\ \text { Oxides of Nitrogen } & 100,000 \text { lbs. } \\ \text { Sulfur Dioxide } & 10,000 \text { lbs. } \\ \text { Carbon Dioxide } & 100,000 \text { lbs. }\end{array}$

OPEN ISSUES :

Worker exposure design base dose limit per DOE N 5480.6 IS less than 500 mrem per year with ALARA considerations incorporated. 


\section{Module D: Spent Fuel Repackaging Facility}

EACILITY DESCRIPTION:

The fuel repackaging facility will be included into the structure that houses the other facilities required for the spent fuel handling activities. The repackaging of failed spent fuel into SST canisters will be performed under water. A pool with dimensions of $20 \times 25$ ft. with a depth of $40 \mathrm{ft}$. will be used to place the failed spent fuels into the canisters.

The pool is interconnected with the other pool facilities with transfer canals. Spent fuels will be transferred underwater to the canning pool by the monorail hoists where they will be placed into SST canisters. The canisters will have provisions for attach a lid to the loading opening with drainage fittings installed at an appropriate location.

The canisters for the purpose of this study are cylindrical shaped with an approximate 5 inches diameter by 15 feet long, but these dimensions may vary with the type of fuel being repackaged. Equipment for the remote handling and cutting of the fuel cans shall be furnished. A shielded transfer bell will be used for the dry transfer of the cans to a welding station.

The welding station will be in a shielded dry cell with remotely operated welding equipment for welding of the lid to the can. An appropriately sized bridge crane will be used to lift the can/bell assembly out of the pool for transfer to the welding station.

Racks in the repackaging pool will provide lag storage for the canisters. Equipment for dewatering/drying the cans and for filling the canisters with inert gas shall be shall be provided. The canisters containing the spent fuel will be transferred back to the storage pool for storage or loaded into a dry storage cask.

\section{INTERFACE WITH EXISTING FACILITIES:}

None 
Section 5

Technical Data summary supporting the INEI spent FueI EIS

Document No. NMP-PIS-930182, Revision 2

Narch 22, 1994

DATA:

Facility Size and Construction: Concrete - 2,220 ft f $^{2}$

Steel frame - $1,080 \mathrm{ft}^{2}$

Critical Design/Safety Features: DOE Order $6430.1 \mathrm{~A}$

Worker exposure dose limit $<500$ mrem/yr

Land Area:

0.4 acres

Land Area Disturbed by Construction:

0.5 acres

Capacity:

$100 \mathrm{MTE}$ equivalent elements per year (Assuming 3\% defective fuel)

Capital Cost:

$\$ 30.0 \mathrm{M}$

Annual Operating Cost:

$\$ 3.0 \mathrm{M}$

Iife Cycle Cost:

$\$ 210.0 \mathrm{M}$

Construction Personnel:

40 peak

Operations personnel:

40

Chemical Inventory:

Nitric Acid

Phosphoric Acid

Oxalic Acid

Sodium Hydroxide

Sodium Dichromate

Betz Slimicide

Sodium Hypochloride

Carbon Dioxide

Polyphosphate

Cleaning solvent

Corrosion inhibitor

Nitrogen

$100 \mathrm{gal}$

100 gal

$100 \mathrm{gal}$

500 lbs.

5001 1bs.

25 lbs./Yr

20 lbs./yr

$2,000 \mathrm{lbs} . / \mathrm{yr}$

$20 \mathrm{lbs} . / \mathrm{yr}$

20 lbs./Yr

20 Ibs./Yr

200 liters 
Section 5

Technical Data Summary supporting the INEI spent Fuel EIS

Document No. NMP-PLS-930182, Revision 2

March 22, 2924

Utility Requirements:

Electricity

Steam

De-ionized water

Cooling water

Domestic water

\section{:}

Canister/MTU

Saltstone (CY/YR)

TRU Waste (CY/YR)

LI Waste (CY/YR)

Sanitary (GAL/YR)

$$
\begin{array}{r}
1,000 \mathrm{MWH} \\
1,000,000 \mathrm{lbs} . \\
2,000,000 \mathrm{gal} \\
300,000 \text { gal } \\
800,000 \text { gal }
\end{array}
$$

Waste:

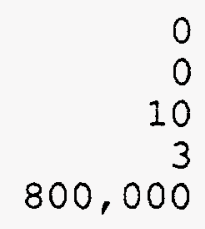

AIR AND LIQUID EMISSIONS BY RELEASE POINTS:

Facility exhaust air streams will be routed through HEPA filters, then into a stack where it is monitored.
VOC
Carbon Monoxide
Total suspended particulate
Oxides of Nitrogen
Sulfur Dioxide
Carbon Dioxide
100 lbs.
500 lbs.
100 lbs.
$1,0001 \mathrm{bs}$.
100 lbs.
1,000 lbs.

OPEN ISSUES:

Worker exposure design base dose limit per DOE $N 5480.6$ is less than 500 mrem per year with ALARA considerations incorporated into the design. 
Section 5

Page 124 of 170

Technical Data Summary Supporting the INEL Spent Fuel EIS

Document No. NMP-PLS-930182, Revision 2

Narch 22, 1924

Module E: Canister Ioading Facility

FACILITY DESCRIPTION:

The spent fuel canister loading facility will be located in the same structure with the other facilities required to completed the spent fuel handiling activities. Lifting service will be provided by a 135 ton crane.

Depending on the technology selected, canister loading could be performed underwater or in a dry cell. For the purpose of this report, it is assumed that the underwater loading method is used. The facility will be a stainless steel lined pool with leak detection and designed as safety class structure and structural integrity ensured following a DBE accordance to DOE order 6430.1A.

Depending on the type of system selected, the spent fuel canister may be shielded. An internal basket assembly will provide a storage position for each fuel assembly. Incorporation of neutron absorbing material into each fuel position ensures subcriticality.

The canister loading process may begin by placing an empty dry storage canister inside a transfer cask, then sealing the annular space between the canister and the cask. The canister and cask is filled with water, then moved by the building main cask crane to the canister loading pool where spent fuel assemblies are loaded into the canister.

The cask is then moved to a pit where it is decontaminated; a shield plug and cover(s) put on the canister opening; then seal welded. A cask working platform will provided access to the top area of the cask. The platform should be readily removable and provide the operator with electrical power, compressed air, tools, sample containers and decontamination supplies. The canister is drained, dewatered and filled with inert gas. The cask/canister is placed on a transport trailer after which a tractor tows the trailer to the dry storage site for interim storage.

INTERFACE WITH EXISTING FACILITIES:

None 
Section 5

Technical Data summary supporting the INEL spent Tuel aIs

Document No. NMP-PIS-930182, Revision 2

Warch 22, 1294

DATA:

Eacility Size and Construction: Concrete - 4,200 $\mathrm{ft}^{2}$

Steel frame - $1,800 \mathrm{ft}^{2}$

Critical Design/ Safety

DOE Order $6430.1 \mathrm{~A}$

Eeatures:

Worker exposure $<500 \mathrm{mrem} / \mathrm{yr}$

Land Area :

0.6 acres

Land Area Disturbed by

1.0 acres

Construction:

- Capacity:

5,000 MTE equivalent elements/yr

Capital Cost:

$\$ 70.0 \mathrm{M}$

Annual Processing Cost:

$\$ 16.0 \mathrm{M}$

Life Cycle Cost:

$\$ 510.0 \mathrm{M}$

Construction Personnel:

50 peak

Operations Personnel:

100

Chemical Inventory:

Nitric Acid

Phosphoric Acid

Oxalic Acid

Sodium Hydroxide

Sodium Dichromate

Betz Slimicide

Sodium Hypochloride

Carbon Dioxide

Polyphosphate

Cleaning solvent

Corrosion inhibitor

Nitrogen

$200 \mathrm{gal}$

$200 \mathrm{gal}$

$100 \mathrm{gal}$

500 Ibs.

500 lbs.

15 lbs./yr

$20 \mathrm{lbs} . / \mathrm{yr}$

1000 lbs./Yr

10 Ibs./yr

10 lbs./yr

10 Ibs./Yr

$2 \mathrm{~kg} / 1$ 
Utility Requirements:

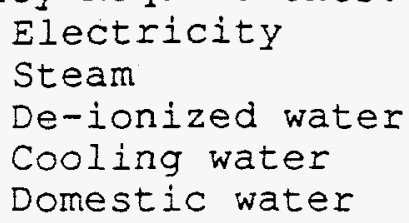

Waste:

Canister/MTU

Saltstone (CY/YR) TRU Waste (CY/YR)

Sanitary. (GAL/YR)

AIR AND LIQUID EMISSIONS BY RELEASE POINTS:

Facility exhausts through HEPA filters and stack is monitored.

VOC

Carbon Monoxide

Total suspended particulate Oxides of Nitrogen

Sulfur Dioxide

Carbon Dioxide
500 lbs.

1,000 lbs.

$3001 \mathrm{lbs}$.

$5,0001 \mathrm{bs}$. 300 lbs.

3,000 lbs.

OPEN ISSUES :

Worker exposure design base dose Iimit per DOE $N 5480.6$ for facility modification should be ALARA which is less than 500 mrem per year. Current canister design shows that 50\% of the dose rate is obtained during the canister cover welding and inspection.

Criticality safety of highly enriched uranium spent fuels requires evaluations for criticality under dry storage. 


\section{Module F: Interim Dry Sterage Facility}

\section{FACILITY DESCRIPTION:}

Based on the system described in The Summary Engineering Description for Eoreign Research Reactor Spent Nuclear Fuel, Report No. B430-93-076, issued by EG\&G Idaho, interim dry storage concept place the assemblies in a modular ventilated vertical dry well storage cell. For the purpose of this study, it is assumed that the only variable is the size of the fuel storage area. The dry storage facility will probably be separated from the other facilities required for the spent fuel handling activities.

The interim dry storage facility site is within a double-fence security area with a perimeter intrusion detection and alarm system(PIDAS) between the fences. The facility consists of roadways and concrete pads on which the horizontal storage modules or vertical storage modules are constructed. The layout shall provide for ready access to any module for removal of its dry canister should a need arise. The spent fuel canisters are loaded into the storage modules by the use of a hydraulic ram, then the module cover is then sealed welded. Natural air circulation convection and conduction through the module roof and walls removes the decay heat from the spent fuels during storage.

INTERFACE WITH EXISTING FACILITIES:

None

DATA:

Facility size and Construction: The facility size will vary to the quantity of spent fuels stored

Critical Design/Safety Features: DOE Order 6430.1A

Worker exposure $<500 \mathrm{mrem} /$ year.

Land Area:

Existing SRS fuels

Research reactor fuels

All fuels (Centralization)

$$
\begin{array}{r}
15 \text { acres } \\
4 \text { acres } \\
60 \text { acres }
\end{array}
$$

Land Area Disturbed by Construction:

Existing SRS fuels

Research Reactor fuels

All fuels (Centralization)
15 acres
4 acres
60 acres

Iimited by canister loading to $\sim 50$ storage modules/yr 
Capital Cost:

Existing SRS fuels
Research Reactor fuels
All fuels (Centralization)

Annual Processing Cost:

Iife Cycle Cost:

Construction Personnel:

Operations Personnel:

Chemical Inventory:

Utility Requirements:

Electricity

Steam

Domestic water

Waste:

Canister/MTU

Saltstone (CY/YR)

TRU Waste (CY/YR)

LL Waste (CY/YR)

Sanitary (GAL/YR)

AIRBORNE AND LIQUID EMISSIONS BY RELEASE POINTS:

None

OPEN ISSUES :

Waste form qualifications will be an issue. Direct disposal of spent fuels in the federal repository requires a costly development program to accommodate the wide variety of spent fuel types.

Worker exposure design base dose limit per DOE N 5480.6 is less than $500 \mathrm{mrem} /$ year with the ALARA concept applied to the design. 


\section{Module G: Interim storage Spent Fuel storage Pool}

\section{EACILITY DESCRIPTION :}

Depending on the options selected, storage pool will be sized to accommodate wet storage of existing SRS and offsite spent fuels. The cost of a pool required to store the entire DOE spent fuel inventory may make the centralization case impractical. The spent fuel storage pool will be located adjacent to the other facilities as required for the spent fuel handling activities. At least, all the aluminum clad spent fuels will be repackaged into a SST canister prior to placement in the new pool.

The pool will be equipped with storage racks for the unloaded spent fuel assemblies. High density racks with neutron absorbing cells to maintain an acceptable keff valve for closed spaced fuel geometry may be used. Rack configuration shall be designed to store all candidate fuels. The pool design will include a water quality control system.

The transfer of fuel from the shipping casks will be performed underwater via a water canal connecting the cask pool and the storage pool. The pools and the canal are stainless steel lined with leak detection capability. Design of the pools and its major systems will be safety class items per DOE Order 6430.1A.

\section{INTERFACE WITH EXISTING FACILITIES:}

The existing Receiving Basin For Offsite Fuels (RBOF) has been in use since the 1960 's, therefore it is approaching the end of its design life, nor does it meet all the requirements for a modern storage pool. It is assumed that sometime in the near future, due to design life, regulatory requirements, and capacity demand; a new storage facility that meets all current standards will be built to accommodate increased rate of spent fuel receipts and increased storage capacity demand.

DATA:

Facility Size and Construction: Concrete $-18,520 \mathrm{ft}^{2}$ Steel frame $-8,280 \mathrm{ft}^{2}$

Critical Design/Safety Features: DOE Order $6430.1 \mathrm{~A}$ Worker exposure $<500 \mathrm{mrem} / \mathrm{yr}$

Land Area:

Land Area Disturbed by Construction:
3.0 acres

3.5 acres 
Section 5

Technical Data Summary Supporting the INEL Spent Fuel aIs

Document No. NMP-PLS-930182, Revision. 2

March 22, 2994

Capacity:

Capital Cost:

Annual Operating Cost:

Life Cycle Cost:

Construction Personnel:

Operations Personnel:

Chemical Inventory:

Nitric Acid

Phosphoric Acid

Oxalic Acid

Sodium Hydroxide

Sodium Dichromate

Betz Slimicide

Sodium Hypochloride

Carbon Dioxide

Polyphosphate

Cleaning solvent

Corrosion inhibitor

Nitrogen

Utility Requirements:

Electricity

Steam

De-ionized water

Cooling water

Domestic water
Capacity will vary according to the case selected

$$
\$ 230.0 \mathrm{M}
$$

$\$ 8.0 \mathrm{M}$

$\$ 760.0 \mathrm{M}$

150 peak

50

$1,000 \mathrm{gal}$

1,000 gal

500 gal

4,000 lbs.

4,000 lbs.

75 lbs./yr

50 1bs./Yr

5,000 lbs./Yr

$501 \mathrm{bs} . / \mathrm{yr}$

$50 \mathrm{lbs} . / \mathrm{Yr}$

$50 \mathrm{lbs} . / \mathrm{Yr}$

2,000 liters

$10,000 \mathrm{MWH}$

0 lbs.

0 gal

0 gal

$1,000,000 \mathrm{gal}$

Waste:

Canister/MTU

Saltstone (CY/YR)

TRU Waste (CY/YR)

LI Waste (CY/YR)

Sanitary (GAL/YR)

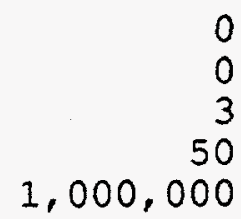


Technical Data Summary supporting the INEL Spent Fuel EIS

Document No. MMP-PIS-930182, Revision 2

March $22, \quad 1994$

AIR AND LIQUID EMISSIONS BY RELEASE POINTS:

The facility exhaust air stream(s) will be routed through HEPA filters, then to a stack where it is monitored.

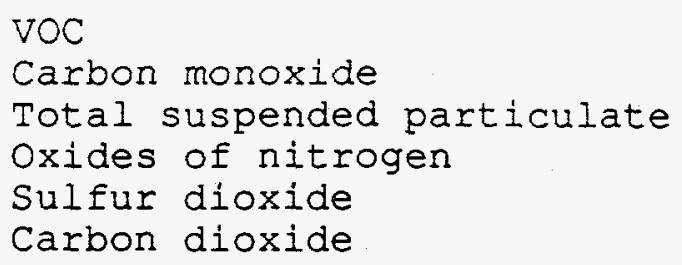

OPEN ISSUES :

Worker exposure design base dose limit per DOE $N 5480.6$ is less than 500 mrem with ALARA considerations incorporated into the design. 
Section 5

Page 132 of 170

Technicai Data Summary supporting the INEL spent Fuel EIS

Document No. NMP-PLS-930182, Revision 2

Varch 22, 1994

Module H:

Fanyen Facility

GENERAL DESCRIPTION

The F-Canyon Facility and the other SRS chemical separation facilities are located in the general area designated as the 200 Area which is near the center of the SRS. The 20OE-Area is one of 13 major operating areas within the SRS. The F-Canyon Facility is housed in the $221-F$ Building.

\section{FACILITY DESCRIPTION}

The 221-F Canyon Facility was completed in 1954 with the primary mission for $\mathrm{pu}$ recovery from reactor targets. It is a largely remote operated facility consisting of a warm canyon, hot canyon, and center section for utilities and services. Overhead cranes are provided in both canyons to allow remote equipment repairs, equipment replacement and process revisions. The canyon facilities have undergone some modernization with replacement of the cranes and various equipment upgrades.

The F-Canyon building is $835 \mathrm{ft}$ long, $122 \mathrm{ft}$ wide, and $66 \mathrm{ft}$ high, with 52 ft extending above grade. The building is comprised of 18 separate sections, one section $85 \mathrm{ft}$ long and 17 sections 43 ft long, separately poured on reinforced concrete foundation slabs. Expansion joints are provided between adjacent sections. These sections, numbered 1-18, serve as references for locations of various systems or processes.

Building 221-F is a reinforced concrete structure which was designed and constructed in the early 1950's as a Maximum Resistance (MR) structure with the applicable DuPont Engineering Standards in effect. By definition, an MR structure which is the highest structural classification at SRS are resistant to the loss of confinement due to DBA's including natural or manmade events.

The facility, service systems, and process systems were designed in accordance with nationally recognized codes and standards as implemented using Dupont Standards and Site Specifications. The facility and process systems have undergone many upgrades and modifications since the initial construction. 
Based on process hazards assessments, certain systems and components were determined to be important or critical to increasing the process or facility safety, thereby decreasing risk. These systems and components were designed with additional safety margins using higher factors of safety, component redundancy, or acceptance criteria than those in the established national codes.

The F-Canyon systems, structures, and components were also designed to comply with federal government requirements established under the various cognizant agencies having facility oversight, such as the Atomic Energy Commission (AEC), the Energy. Research and Development Agency (ERDA), and DOE. These agencies established general design criteria for the facilities within the weapons complex including those at SRS. Presently, the principal design criteria for use at nonreactor nuclear facilities are established in DOE Order 6430.1A. Verbatim compliance of older FCanyon system components and structures to DOE Order 6430.1A guidelines is not possible in some cases; the increased risks associated with the noncompliance items must be acceptably small; otherwise system upgrades and redesign are implemented.

\section{PROCESS DESCRIPTION:}

The F-Canyon Facility was designed primarily for recovery of plutonium from irradiated or unirradiated targets. Other special isotopes have been recovered on a programmatic basis. The FCanyon Facility utilizes the PUREX Process to recover these materials.

The process equipment consists of two dissolvers with centrifuges for feed clarification and several solvent extraction systems. The first solvent extraction bank separates the dissolved solution into a fission product high level waste stream and a plutonium/U238 product stream. The second bank extraction system separates the plutonium from the $\mathrm{U}^{238}$, while the third separates the $\mathrm{U}^{238}$ from the solvent stream.

Both of these product streams then undergoes an additional solvent extraction purification process. The $U^{238}$ stream is then sent to the FA-Iine facility where it is converted into $\mathrm{UO}_{3}$ by evaporation and denitration, then drummed for storage. The plutonium stream is sent to the FB-Line facility for conversion to plutonium metal or oxide as required by the DOE. 
Section 5

Technical Data summary supporting the INEL Spent Fuel EIS

Document No. NMP-PLS-930182, Revision 2

March 22, 2994

For over a decade the canyon has also purified additional unirradiated feed materials dissolved in EB-Iine recovery

facilities as well as scrub alloy buttons from Rocky Flats through direct dissolution in canyon dissolvers. In 1991, direct

dissolution of out-of specification plutonium metal in the canyon dissolvers was also demonstrated. Adequate purification of these streams with only one bank of solvent extraction has been demonstrated; therefore the processing of these materials will require fewer process steps.

Additionally, the canyon recovers over $95 \%$ of the acid used in processing yielding an extremely waste efficient processing approach. The canyon is also used to stabilize plutonium from special aluminum clad spent fuels.

FACILITY DATA:

Description of Processed Materials:

All SRS low enriched Alclad fuels and targets.

Facilities Upgrades/ Modifications

Required:

None

Facility Size:

Facility Construction:

Critical Design/Safety Features:

$835^{\prime} \times 122^{\prime}$

Reinforced concrete

Maximum Resistance Class

Nuclear Criticality \&

Contamination Control

Land Area :

$1,500^{\prime} \times 600^{\prime}$

Land Area Disturbed by Construction:

None

Capacity:

$600 \mathrm{MTHM} / \mathrm{Yr}$.

Utility Requirements:

Electricity

Steam

Cooling water

Capital Cost:

$\mathrm{N} / \mathrm{A}$

Annual Operating Cost:

$\$ 50.0 \mathrm{M}$

Iife Cycle Cost:

$\mathrm{N} / \mathrm{A}$ 


\author{
Schedule: \\ Time to Begin \\ Time to Complete
}

Annual Construction Personnel:

Annual Operations Personnel:

Chemical Requirements:

Waste:

Canisters (MTU)
Saltstone (CY/MTU)
TRU (CY/MTU)
Sanitary (gal/Yr.)

AIRBORNE AND LIQUID EMISSIONS BY RELEASE POINT:

See attachments.

OPEN ISSUES :

The F-Canyon Facility will be subject to the EIS process before continued operations can resume.
2 years

5 years

$\mathrm{N} / \mathrm{A}$

515

See $F$ Canyon Safety

Analysis Reports (SAR) 
The EB-Line facility which started up in 1959 consists of processes located in gloveboxes in a hardened structure located on top of the 221-F Canyon Building. This facility is designed to process the low concentration plutonium solution from the canyon into plutonium metal or oxide.

The mainline processes consist of cation exchange to concentrate the solution followed by precipitation, drying, calcining and roasting furnaces which convert the trifluoride intermediary compounds to a mixture of plutonium oxide and plutonium tetrafluoride. In induction furnaces, the plutonium tetrafluoride is reduced the plutonium to metal. The finished product (normally plutonium metal buttons) is sampled, weighed, pickled, and packaged. With limited process modifications, plutonium oxide product can also be produced in the same equipment by precipitating plutonium oxalate, then calcining the cake to oxide.

Recovery facilities are provided to dissolve and purify via anion exchange between the primary liquid solution and solid process residues. Residues have been historically processed with essentially complete plutonium recovery shortly after generation with minimal backlog.

A small glovebox process for the dissolution of plutonium oxide and metal has been used extensively for dissolution of offsite feed materials. However, this process is at the end of its useful life. The New Special Recovery Facility has been constructed to replace this operation.

Extensive restoration of the FB-Iine facility has been in progress for the last decade. These efforts have been extremely successful in reducing the radiation exposure and assimilation risk associated with continued operation.

FACILITY DATA:

Eacility Size/Construction: In the 221-F Building

Critical Design/Safety Features: See FB-Iine SAR

Land Area:

$\mathrm{N} / \mathrm{A}$

Land Area Disturbed by Construction: N/A

Capacity :

$37 \mathrm{MTU} / \mathrm{yr}$. 
Capital Cost:

Annual Operating Cost:

Life Cycle Cost:

Construction Personnel:

Operations Personnel:

Chemical Inventory:

Tributyl Phosphate

N-Paraffins

Nitric Acid

Sodium Hydroxide

Ammonium (Ceric) Nitrate

Freon 113

Hydroxlamine Nitrate

Silver Nitrate

Hydrazine Mononitrate

Uranyl Nitrate Hexahydrate

Phosphoric Acid

Sulfamic Acid

Utility Requirements:

\section{Electricity}

Steam

Cooling water
$N / A$

$\$ 90.0 \mathrm{M}$

$\mathrm{N} / \mathrm{A}$

100

500

Waste:

Canister/MTU

Saltstone (CY/YR)

TRU Waste (CY/YR)

IL Waste (CY/YR)

Sanitary (GAL/YR)
Gelatin

Resin, Ionac Anion

Ferrous Sulfamate

Manganous Nitrate

Potassium Eluoride

Potassium Permanganate

Sodium Carbonate

Mercury

Sodium Nitrite

Oxalic Acid

Boric Acid

Process Water

AIRBORNE AND LIQUID EMISSIONS BY RELEASE POINTS:

See attachments.

OREN ISSUES :

An EIS for the facility may be required before the operations can resume. 
Section 5

Technical Data summary supporting the INEI spent Fuel EIs

Document No. NMP-PLS-930182, Revision 2

March 22, 1924

Module J -

A-canyon Facility

FACILITY LOCATION:

The 200 Areas facilities are located near the center of the SRS. The $200 \mathrm{H}$-Area is one of 13 major operating areas within the SRS. The H-Canyon Facility is located in the 221-H Building. Also, located in the 200 Areas are F-Area, S-Area, Z-Area, and the Mixed Waste Management Facility (Burial Grounds).

\section{PROCESS DESCRIPTION :}

The primary purpose of the H-Canyon is to chemicaliy recover the HEU contained in the spent fuels from the SRS reactors. The HM Process utilized in $\mathrm{H}$-Canyon removes the waste materials and recovers the HEU for DOE uses.

Primary operations include dissolution, chemical and physical separation followed purification of the materials. Process operations are designed to mainly recover the HEU; however there are recoverable quantities of plutonium, and neptunium in the spent fuels. After separation from the HEU, the process solutions which contain these elements are sent to the HB-Iine Facility for recovery.

The HM Process is a PUREX-type Process which has been modified to handle the HEU contained in the spent fuels. Unlike the PUREX process where the aluminum contained in the cladding is chemically separated from the uranium; the HM Process catalytically dissolves the aluminum with the uranium, then uses it as a salting agent in the solvent extraction process. The HM process capacity is limited by the aluminum content instead of uranium.

OUTSIDE FACILITIES DESCRIPTION:

The H-Canyon Outside facilities (Building 211-H) which are located adjacent to the 221-H Building comprise a number of process, utility, and service facilities that support the building facilities. Included are storage of liquid uranyl:nitrate and bulk chemicals, water handling, acid recovery, general purpose evaporation, and segregated solvent facilities. In addition, services for water, electricity, and steam are provided. 


\section{1-H BUILDING DESCRIPTION:}

The reinforced concrete structure is designed and built as a Maximum Resistance (MR) structure, the highest structural classification at SRS. MR structures are built to resist loss of confinement integrity in all DBA's, including those from natural phenomenon or process related accidents such as explosions. Building 221-H was designed and constructed in the early 1950 's in accordance with applicable Dupont Engineering Standards. The facility and process systems have undergone many upgrades and modifications since initial construction.

The H-Canyon building is 835 feet long, 122 feet wide, and 66 feet high with 52 feet extending above grade. The building is comprised of eighteen separate sections with one section 85 feet long while the other seventeen sections are 43 feet long, separately poured on reinforced concrete foundation slabs. Expansion joints are provided between the sections. These sections, which are numbered 1-18, serve as reference points for locations of various systems and processes.

As with the building, the service and process systems were designed in accordance with nationally recognized codes and standards using DuPont Standards and Site Specifications. Based on process hazards assessments, certain systems and components were determined to be important or critical to increasing process or facility safety, thereby decreasing risk. These systems and components were designed with additional safety margins using higher factors of safety, component redundancy, and/or acceptance criteria than those in the established national codes.

The H-Canyon systems, structures, and components were also designed to comply with federal government requirements established under the various cognizant agencies having plant oversight, such as the Atomic Energy Commission (AEC), the Energy Research and Development Agency (ERDA), and DOE. These agencies established general design criteria for the facilities within the weapons complex including those at SRS. Presently, the principal design criteria for use at nonreactor nuclear facilities are established in DOE Order 6430.1A. Verbatim compliance of older HCanyon system components and structures to DOE Order 6430.1A guidelines is not possible in some cases. If the increased risks associated with the noncompliance items are not acceptably small, system upgrades and/or redesign are implemented. 
Section 5

Technical Data summary supporting the INEL spent Fuel EIS

Document No. NMP-PLS-930182, Revision 2

March 22, 1994

DATA :

Eacility Size and Construction: $835^{\prime} \times 122^{\prime}$ Hardened concrete

Critical Design/Safety Features: See the H-Canyon SAR

Land Area:

$1500^{\prime} \times 600^{\circ}$

Land Area Disturbed by Construction:

$\mathrm{N} / \mathrm{A}$

Capacity:

$10 \mathrm{MTU} / \mathrm{yr}$.

Capital Cost:

$\mathrm{N} / \mathrm{A}$

Annual Operating Cost:

$\$ 80.0 \mathrm{M}$

Life Cycle Cost:

$\mathrm{N} / \mathrm{A}$

Construction Personnel:

250

Operations Personnel:

350

Chemical Inventory:

Tributyl Phosphate

Gelatin

$\mathrm{N}$-Paraffins

Nitric Acid

Sodium Hydroxide

Ammonium (Ceric) Nitrate

Freon 113

Hydroxlamine Nitrate

Silver Nitrate

Mercuric Nitrate

Uranyl Nitrate Hexahydrate

Phosphoric Acid

Sulfamic Acid

Resin, Ionac Anion

Ferrous Sulfamate

Manganous Nitrate

Potassium Fluoride

Potassium Permanganate

Sodium Carbonate

Mercury

Sodium Nitrite

Oxalic Acid

Boric Acid

Process Water

Hydrazine Mononitrate

Utility Requirements:

Electricity

Steam

Cooling Water

Waste:

Canister/MTU

Saltstone (CY/YR)

TRU Waste (CY/YR)

LI Waste (CY/YR)

Sanitary (GAL/YR)

$$
\begin{aligned}
& 25,000 \text { MWH } \\
& 5 \times 10^{6} \text { Ibs. } \\
& 8 \times 10^{7} \text { gals. }
\end{aligned}
$$


Section 5

Technical Data Summary supporting the INEL Spent Fuel EIS

Document No, NMP-PLS-930182, Revision 2

Narah 22, 1994

AIR AND LIQUID EMISSIONS BY RELEASE POINTS:

See attached report.

OPEN ISSUES:

A large annual budget is required to support operations. There is a proliferation concern with HEU production. An EIS may be required to continue operations. 
Section. 5

Technical Data Sumary supporting the INEL spent Fuel EIS

Document No. NMP-PLS-930182, Revision 2

Narch 22,1994

\section{Module K - Uranium Solidification Facility}

EACILITY DESCRIPTION

The Uranium Solidification Facility (USF) is housed within

the 221-H Building. The USF converts the dilute liquid uranyl

nitrate (UN) solution into solid uranium oxide (UO3). The process

uses three stages of evaporation followed by a paddle-stirred

continuous denitrator. Once in solid form, the $\mathrm{UO}_{3}$ is assayed, then packaged into geometrically safe containers for storage in a vault. Subsequently, the $\mathrm{UO}_{3}$ is shipped to the Oak Ridge site for DOE uses.

FACILITY DATA:

Facility Size/Construction:

Critical Design/Safety Features:

Land Area :

Land Area Disturbed by Construction:

Capacity:

Utility Requirements:

Electricity

Steam

Cooling Water

Capital Cost:

Annual Operating Cost:

Life Cycle

Schedule:

Time to Begin

Time to Complete

Annual Construction Personnel:

Annual Operations Personnel:
$1,330 \mathrm{ft}^{2}$ in $221-\mathrm{H}$ Building

High Resistance Class 1

$\mathrm{N} / \mathrm{A}$

N/A

$8,000 \mathrm{~kg} / \mathrm{yr}$

TBD

TBD

TBD

$\mathrm{N} / \mathrm{A}$

$\$ 16.0 \mathrm{M}$

N/A

TBD

TBD

80

125 
Saction 5

Technical Data summary Supporting the INeI spent Fuel EIS

Document No. MMP-PLS-930182, Revision 2

March 22, 1924

Chemical Inventory:

See USF Safety Analysis

Reports (SAR)

Waste:

Canisters (MTU)

TBD

TBD

Saltstone (CY/MTU)

TBD

Sanitary (gal/yr.)

TBD

LIQUID AND AIRBORNE EMISSIONS BY RELEASE POINT:

See the USF Safety Analysis Report.

OPEN ISSUES :

Completion of the facility is uncertain at this time. 


\section{Module I - BB-Iine Facility}

\section{FACILITY DESCRIPTION}

The HB-Iine is located atop the 221-H Building. HB-Iine is used to recover $\mathrm{NP}$ and $\mathrm{Pu}$ in solutions received from H-Canyon. This is accomplished by chemically adjusting the solutions, then passing them through ion exchange resin columns. The $\mathrm{Np}$ and $\mathrm{Pu}$ are then eluted from the resins, then converted into oxides by further chemical processing.

DATA :

Facility Size/Construction:

Critical Design/Safety Eeatures:

Land Area:

Land Area Disturbed by Construction:

Capacity:

Utility Requirements:

Electricity

Steam

Cooling water

Capital Cost:

Annual Operating Cost

Life Cycle Cost:

Schedule:

Time to Begin

Time to Complete
Located in the 221-H Building

See 221-H Building

description

$\mathrm{N} / \mathrm{A}$

$\mathrm{N} / \mathrm{A}$

Classified

Included in the H-Canyon costs

$\mathrm{N} / \mathrm{A}$

$\$ 29.0 \mathrm{M}$

$\mathrm{N} / \mathrm{A}$

2 years

6 years 
Section 5

Technical Data Summary Supporting the INEL spent $\bar{T}$ uel eIs

Document No. NMP-PLS-930182, Revision 2

March 22, 1294

Annual Construction Personnel: N/A

Annual Operations Personnel: $\quad 274$

Chemical Requirements: See HB-Line SAR

Waste:

Canisters/MTU

Saltstone (CY/MTU)

TRU Waste (CY/MTU)

Sanitary (gal/yr.)

LIQUID AND AIRBORNE EMISSIONS BY RELEASE POINT:

See attachments.

OPEN ISSUES

Continued operations are uncertain at this time. 


\section{Module M - Reactor Disassembly Basins}

\section{EACILITY DESCRIPTION :}

The disassembly area consists of seven interconnected, waterfilled (except the dry cave) basins in which irradiated assemblies are stored, disassembled, prepared for shipping, and shipped for chemical processing, or, in the case of scrap, burial. The walls between these seven areas have narrow vertical openings at strategic points to permit material transfer. The openings can be closed by portable stoplogs when necessary. The disassembly area also includes equipment for cleaning and cooling the water and for handling the shipping casks. The seven basins that comprise the reactor disassembly basin facilities are:

- Vertical tube storage (including the D\&E canal)

- Machine basin

- Emergency basin

- Dry cave basin

- Inspection basin (monitor basin)

- Horizontal bundle and bucket storage basin

- Shipping transfer basin (pits)

Irradiated fuel, targets, and miscellaneous components are removed from the reactor by the discharge machine during charge/discharge operation. The discharge machine moves assemblies across the process room floor to the D\&E canal. At the canal, it places the assemblies in a holder called the "golf bag" which is part of the D\&E conveyor. The D\&E conveyor carries the assemblies through the water-filled canal under the shielding wall separating the disassembly area from the reactor process room. These components are then transferred to hangers suspended from monorails used to store and transport the assemblies throughout the disassembly area. The assemblies are initially stored in the VTS basin until the nuclear decay heat is low enough to process the components for shipment. This storage area contains 48 storage lanes, each approximately 46 feet long. Two of the lanes are for movement of the hangers between pickup points in the D\&E canal and the transfer crane.

VTS is isolated from the remainder of the basin throughout the decay period to control the spread of radioactivity. Storage time depends on the type of assembly and its irradiation history. The VTS monorails used for storage are arranged in adjacent rows. The large number of assemblies stored in VTS presents the greatest criticality concern in the disassembly area. Failure of two or more adjacent monorails could cause the assemblies to fall into a critical configuration. The storage monorails and hangers have therefore been modified to prevent the assemblies from being stored on adjacent rows. Hanger usage and other criticality safety requirements are described in written procedures. 
Assemblies with failed cladding are required to be discharged, with their associated housings from the reactor to prevent releasing significant amounts of radioactivity to the reactor moderator. Before discharge, the decay heat in the assembly must be allowed to decrease until the standard failed assembly container (harp) can cool the assembly. The harp is designed to provide natural convective cooling of the assembly while isolating the assembly and the leaking radioactive isotopes from the disassembly basin. The harp is also designed to contain the failed assembly during shipment.

The multipurpose functioning of the harp results in a design with limited heat transfer capabilities because the length of the sleeve housing (prior to cutting operations) will not permit natural convective cooling. A reactor must be shut down for approximately 80 hours for the decay heat to decrease so that the harp can adequately cool the assembly in the most restrictive configuration.

The assemblies are moved to the machine basin from VTS after radioactive heat generation has decayed sufficiently to permit further processing. In the machine basin, components are disassembled and prepared for shipping. Remotely operated power tools (electrically or hydraulically powered) submerged in the basin are used to process components. This equipment is operated by personnel on the walkways over the basin.

Manual, long-handled tools are used to position components and remove small pieces in the basins. Slug type fuel and target assemblies are disassembled on the vertical destacker, and the slugs are placed in buckets. Lithium inner targets are removed from tubular fuel assemblies on the vertical disassembly machine. Aluminum extensions on fuel tubes, lithium target tubes, and control rods are cut off using the underwater saw. The tubes or rods are placed in separate fuel, target, or control rod bundles on the assembly bundling tables. The outer targets on Mark 22 assemblies are removed in the horizontal disassembly machine and also placed in target bundles. Scrap parts (e.g., aluminum extensions, inner housings, orifice components, sleeve housings, etc.) are cut into short lengths using the underwater saw, or flattened and sheared into short lengths in the foil-press-shear machine, then placed in scrap buckets.

Nuclear criticality control in the machine basin is provided by administratively. controlling the number of fissile assemblies present. Administrative control of the number of fissile assemblies present in the machine basin is sufficient to prevent criticality at all equipment stations except the underwater saw and the foil-press-and-shear. These machines change the shape of 
the material presented to them, which can greatly decrease the amount of fissile material required to achieve criticality. As a result, control of the number of fissile assemblies is not sufficient protection and additional safeguards are provided.

The underwater saw uses saw stops that ensure cuts are not made through a fuel region. The saw stops are set for each type of assembly. A radiation detector is provided at the foil-pressshear machine. This detector identifies the strong gamma field present in irradiated fuel. The fuel detection alarm is not sensitive to unirradiated fuel that might be discharged in an emergency. However, the primary protection afforded by administrative control of assemblies and personnel training in assembly identification makes crushing slightly irradiated fuel extremely unlikely. The criticality protection provided at the underwater saw and foil-press-shear machine also prevents cutting or crushing fuel or targets and releasing fission products or tritium which would contaminate the basin.

After disassembly, the slug and scrap buckets and the tubular fuel and target bundles are moved from the machine basin to the bucket and horizontal storage, respectively. Twenty-two lanes, each approximately 143 feet long, are provided for the storage of buckets of fuel slugs and scrap metal. Fuel and targets containing volatile fission products are stored until they have decayed to acceptable levels. Fuel, targets, and scrap material are all stored separately with minimum prescribed distances maintained between component types at all times. Tubular fuel is stored only in horizontal storage racks. The racks provide the proper critically safe spacing for tube bundles. Procedures do not allow heavy loads that might crush the racks to be moved over them. Target slug and scrap buckets are not transported over top of the horizontal storage racks or fissile slug buckets at any time. Bucket contents spilling into the racks could affect the criticality properties of the stored fuel as well as damage the racks. Spacers are placed in the racks to prevent the insertion of too many fuel bundles in a storage rack slot. The limits of average pitch between rows and height of row in assemblies for horizontal storage have been tabulated for various fuel types and the margins for reactivity analyzed for deviations in configuration, burnup, and displacement of water. The actual horizontal storage configuration has a large margin of subcriticality.

Fissile slugs are stored in steel buckets. The buckets are stored on the basin floor separate from other materials. The buckets are designed to maintain appropriate separation between them. Procedural limits are used to control the height the buckets can be stacked which protects against objects being dropped onto the stacked array. 
Irradiated material, ready for shipping, is transferred from horizontal storage to the transfer bay. The transfer bay has two water-filled basins called transfer pits that are connected to horizontal storage by a canal. Shipping casks are placed in the transfer pit and irradiated material is placed in the casks using hoists mounted on the monorail system.

Shipping casks are transported to and from the reactor areas by tractor trailer or railroad. Trailers or railcars are positioned adjacent to the transfer pit and casks are lifted into the basin using an 85-ton overhead crane that can travel the length of the transfer bay. Fuel bundles and target buckets are shipped in 70ton casks, or if contained in a failed assembly harp, to a 55-ton failed assembly cask. The 70- and 55-ton casks are transported by rail. Lithium targets are shipped in a tractor-trailer-mounted, 45-ton cask. Scrap material is shipped to the burial ground in a 15-ton cask. The material in the 45- and 50-ton casks does not generate a significant amount of heat; therefore, water is drained from the casks before shipping.

Assemblies loaded in the 70- and 55-ton casks are heat generating. These casks are designed to transfer the heat to the environment. Heat transfer calculations are performed then reviewed to ensure adequate heat transfer before a cask is loaded. Each cask has several thermocouples installed to monitor temperatures. After a cask is removed from the basin for loading on its flatcar, temperatures are taken at regular intervals. These casks are left water-filled after loading. The water is necessary for proper heat transfer between the assemblies and the cask wall. Analysis has shown that a drained cask has a heat transfer rate that would prevent melting of assemblies.

Arrays of fissile assemblies containing enough material to become critical are assembled in the 70-ton casks. Neutron absorbing material is installed within the fissile array to avoid criticality. The neutron absorbing material is in the form of cadmium separator plates that are placed between the fuel bundle slots of the 70-ton cask. Also, alternate fuel bundle slots are blocked to control the total fissile mass in the cask. Only 70ton casks are designated to carry fuel bundles are modified with cadmium plates. Casks without plates are used to carry target slugs but can be converted to use for fuel bundle operation.

Poison plates are tested for adequate neutron absorption before a 70-ton cask is placed in service, after conversion from slug operation, after maintenance work on the plates, and at specified intervals while the cask is in service. 
Disassembly basin levels are monitored continuously and maintained by manual control. Basin water levels are expressed as inches below the Building 105 grade elevation of 0.0 inches. Normal basin levels are controlled between $-13-1 / 2$ and $-16-1 / 2$ inches. Prior to charge and discharge operations, the basin level must be reduced to between -15 and -16 inches.

Makeup water for the Disassembly Basin is supplied from headers $\mathrm{CW}-39$ (normally) and $\mathrm{RW}-1$ (backup). A motor-operated valve in the basin supply line from each header which is operated from the central control room is normally open. Air-operated valves in each line are positioned by a preumatic control system to maintain basin water level within the preset limits. The motor-operated valves in the makeup lines from $C W-39$ and $R W-1$ receive 480 volt $A C$ power from $\mathrm{MCC}-31 \mathrm{E}$ and $\mathrm{MCC}-13 \mathrm{E} 2$, respectively. Pneumatic valves in the makeup lines from $\mathrm{CW}-39$ and $\mathrm{RW}-1$ as well as the pneumatic level. control system are supplied with instrument air with backup available from the Building 191 standby air system. The valves fail open on loss of air.

If the basin level drops to -27 inches, the water seal between the process room and the disassembly basin will be lost with the possibility of contaminants spreading from the process room to clean areas of the building greatly increased.

A high basin water level resulting in overflow is also of concern in disassembly operations. The disassembly area is connected to the main reactor building by hallways, elevator shafts, and cable shafts. For this reason, overflow of the disassembly basin could cause equipment malfunctions and spread low-level contamination in the flooded areas. Uncontrolled water level increases could result from leakage in basin makeup water valves, shell-to-tube leaks in the basin heat exchangers, or improper use of shipping cask decontamination hoses. Basin level instrumentation with alarms in the CCR and procedures that protect against low and high water levels are provided. If an unexplained basin water level increase occurs, water is purged through the basin deionizers to seepage basins to slow the increase until the inleakage can be stopped. Basin overflow weirs are provided at 11 inches below grade to drain water at a rate greater than most credible addition methods. These weirs drain to the process sewer, which empties into the effluent canal. The disassembly basin water level monitors are functionaliy tested once per year.

The dry cave is a shielded enclosure in which radioactive components can be removed from the basin and inspected or worked on remotely. It has its own filtered air exhaust system to remove radioactive contaminants. The dry cave currently has no production function and is used as a miscellaneous storage area. 
Section 5

Technical Data summary supporting the INEL spent Fuel EIs

Document No. NMP-PLS-930182, Revision 2

Narch 22, 1994

The inspection basin is a small isolated section of basin intended for special development work. It is currently used for nonfissile storage.

The emergency pump suction well is the primary source of water to the chillers and provides a last resort emergency source of cooling water to header $\mathrm{CW}-2$. The emergency well is connected to the remainder of the basin by a weir gate. This gate is procedurally verified to be open during reactor operation.

DisassembIy VTS is a secondary source of light water for discharged assembly cooling. A dedicated pump located near the D\&E canal supplies VTS water to the discharge machine. Flow rates for this system are low, therefore would not significantly affect the VTS level.

FACILITY DATA:

Facility Size/Construction:

Critical Design/Safety Features:

Land Area:

Land Area Disturbed by Construction:

Capacity:

Utility Requirements:

$$
\text { Electricity }
$$

Steam

cooling water

Capital Cost:

Annual Operating cost

Life Cycle cost

Schedule:

Time to Begin

Time to Complete $280^{\prime} \times 120^{\prime} /$ reactor

Reinforced Concrete

Maximum Resistance Class

Nuclear Criticality

Contamination Control

$50,000 \mathrm{ft} .2 /$ reactor

$\mathrm{N} / \mathrm{A}$

1200 carriers in tube storage and 800 buckets in bucket storage 
Section' 5

Technical Data Summary Supporting the INEL spent. Fuel EIs

Document No. MMP-PIS-930182, Revision 2

March 22,2994

Annual Construction Personnel:

0

Annual Operations Personnel:

120 staff/basin

Chemical Inventory:

See Reactors Disassembly Basin SAR

Waste:

Canisters (MTU)

Saltstone (CY/MTU)

TRU (CY/MTU)

Sanitary (gal/yr.)

LIQUID AND AIRBORNE EMISSIONS BY RELEASE POINT:

OPEN ISSUES : 
Section 5

Technical Data sumary supporting the INEL spent Fuel EIS

Document No. NMP-RLS-930182, Revision 2

March 22. 2994

\section{Module N - Receiving Basin for effsite Fuels}

\section{GENERAL DESCRIPTION}

RBOE is a versatile facility for the receipt and storage of irradiated nuclear spent fuel. Most of the irradiated spent fuels are received from offsite reactors with only occasionally receipts from SRS reactors. The RBOF provides the capability for underwater unloading of shipping casks plus the capabilities to receive and store spent fuel elements. Spent fuel may be shipped to either of the two SRS separations facilities for processing, to the Savannah River Technology Center for testing, or to an offsite location. Alternatively, the spent fuels may be stored for long periods of time. Primary radiation shielding is provided by the water which covers the fuels.

Impurities and radioactivity are removed from the basin water by means of a filter-deionizer system. The ion exchange resins employed in this system are regenerated within the RBOF. The portable deionizers employed at the SRS reactor storage basins are transported to the RBOF for regeneration. Irradiated lithiumaluminum targets and control rods are also washed at RBOF during transfer from the SRS reactors to tritium separation facilities.

The 200-Areas located near the center of the site include two separations facilities designated as $F$ and $H$ Areas. The RBOF facility is located in $\mathrm{H}$-Area on a two acre site. A railroad track terminates within the facility while a roadway provides access for trucks. Other adjoining facilities in the H-Area include a chemical separations plant and support facilities for the production of purified nuclear materials which include plutonium, tritium, and uranium.

\section{FACILITY DESCRIPTION:}

RBOF which is designated as Building $244-\mathrm{H}$ consists of $139^{\prime}$ wide $x$ 148' long by 45' high structure which encloses a number of waterfilled basins that extend to a maximum below-grade depth of $45^{\prime}$. The above-grade structure is fabricated from standard, structuralsteel members with exterior walls of both Transite and concrete block. Walls are insulated with 4.5 " of Fiberglas ${ }^{(3)}$. In the basin area of the building, the insulation is protected from water damage by an interior wall of Transite ${ }^{(}$. The roof supported by long span steel joists consists of 20-year design life type builtup roofing. Personnel access to the building is by means of six doorways. Fuel shipping casks are admitted through a door in the truck and railcar dock. An assortment of hardware used to bundle and store fuel in the basins is stored outdoors in racks near the southwest corner of the building. 
The Resin Generation Eacility (Building 245-H) is a small structure which adjoins the west side of RBOF. Structural details of construction are similar to those of the RBOF facility.

Materials employed for the operation of the RBOF facility are stored in the 244-1H Storage Building. A trailer, designated as Office Building 244-2H, located south of Buildings 244-H and 245$\mathrm{H}$, provides office space for operations personnel.

\section{PROCESS DESCRIPTION :}

Casks containing spent fuel elements are delivered to the dock on the north side of the RBOF facility by either truck or railcar. only certified shipping casks are used for offsite fuels. Entry of transport vehicles into the dock is by means of a roll-up door on the west side of the carport. Tractors with cask trailers are positioned outside the carport, facing away from the carport opening, and astride the centerline of the carport. Trains are required to stop approximately 200' from the dock while a derailer is removed from the tracks.

A radiation survey of the cask is followed by the removal of the cask hold-down frame. Next, a 100-ton crane is used to transfer, then lower the cask to the bottom of the cask wash pit.

The cask is washed to remove any dirt that may have been acquired in transit. The wash pit is equipped to perform decontamination of casks as necessary. Cask-lid bolts are loosened or removed prior to the transfer of the cask by crane to the cask basin.

The cask wash pit is $12^{\prime}$ long by $27^{\prime}$ wide by $15^{\prime}$ deep. The cask basin is $13^{\prime}$ long by $27^{\prime}$ wide by $29^{\prime}$ deep. At the north side of the basin, there is a $9.5^{\prime}$ diameter by 26' deep pit in the floor of the basin.

The cask is lowered into the cask basin until the top of the lid is about three feet above the water surface at which point the crane hoist travel is halted to permit manual removal of the remaining lid bolts. The cask is then lowered to the bottom of the basin. As the cask sits on the bottom, the cask lid is removed with a crane, then stored temporarily on the bottom. The fuel basket (or fuel transfer bucket) is moved through an underwater door that connects the cask basin to the canal system by means of a traveling bridge monorail system. 
Section 5

Technical Data Summary supporting the INEL Spent Fuel EIS

Document No. NMP-PLS-930182, Revialon 2

March 22. 1924

The two storage basins each contain a vertical array of racks that serve to delineate the many individual spaces that are available for the storage of fuel. The inspection basin has the necessary space and equipment to the examine and analyze the fuels. The disassembly basin is utilized to disassemble the fuels into the various components by mechanical means.

The below-grade basins of the RBOF facility are of reinforced concrete with walls that are stepped in thickness from $3^{\prime}$ at grade to $6.5^{\prime}$ at $2^{\prime}$ ' below grade. Basin floors are $3^{\prime}$ thick. Deionized water is used in the water-filled basins. To prevent leaching of the concrete and to provide easily decontaminated surfaces, the interior surfaces of the basins are coated or lined.

Walls studs and bolt holes in the walls and floors are provided in the basins for the installation of underwater equipment.

Underwater illumination is provided by 1,000-watt mercury-vapor lamps. which are housed in the recesses along the basin walls and by portable 500-watt incandescent lights. Guard rails surround all basins. The canals are covered with removable gratings, with the exception of sections outside the disassembly basin and inspection basin. Transfers between each basin utilizing the canal system are via underwater doors.

Spent fuels destined for SRS reprocessing facilities or offsite shipment are loaded into bundles, packaged and stored until needed. The offsite shipment of fuel entails a reversal of some of the operations previously described.

Three concrete pedestals or shims are available to adjust the height of casks placed within the 16' deep pit of the cask basin. These shims are $8^{\prime}$ in diameter vary in height from $1.5^{\prime}, 3^{\prime}$, and 6' high, which weigh 6, 9, and 14 tons respectively. The top surface of each shim is covered with a $0.25^{\prime \prime}$ thick stainless steel plate. All exposed concrete surfaces are painted with Phenoline AE-600 A painted, carbon-steel yoke is used in conjunction with a 100-ton capacity crane to move the shims.

All transfer canals are $3^{\prime}$ wide by $29^{\prime}$ deep. With the exception of portions of the canal outside of the disassembly and inspection basins, all of the canals are covered with removable gratings. Seven underwater doors serve to compartmentalize the basin transfer canal system into eight sections. Each door and frame is a matched assembly. Seven of the doors are 29' 2 " high, one is 14'2" high, and all are 2'10.5" wide and 3.5" thick. The doors are hollow, welded structures fabricated from Type 304 stainless steel. 
Technical Data sumary supporting the INEI spent Fuel EIS

Document No. NMP-PLS-930182, Revision 2

March 22, 1294

The larger of the two storage basins is $40^{\prime}$ ' long by $27^{\prime}$ wide with part of the basin having a depth of $22^{\prime}$ and the other part a depth of 29'. Intact fuel assemblies along with bundled spent fuel assemblies are normally stored in 42 rows of the storage basin. These rows are defined by a vertical framework of racks constructed of aluminum I-beams with a height of 11'2". Gratings, guide plates, and spacers, referred to collectively as "hardware", are installed between the racks to define the individual storage spaces along the rows. The racks are spaced so that there are 21 rows with 9 " center-to-center rack spacing, 18 rows with 12 " center-to-center rack spacing, and one row each with 25.5", 16", and $11 "$ center-to-center rack spacing. The effective storage space in each row is $16^{\prime}$. The vertical height of the racks is 11'2". The hardware between the racks serves both to support and to properly separate the stored fuel.

It is sometimes necessary (or convenient) to store fuel in reactor-slug buckets. The bucket storage racks located in the southeast corner of the storage basin provide space for 70 buckets. If the integrity of the spent fuel cladding is suspect, the spent fuel is placed in an isolation container, referred to as a "test tube", then stored in a special rack near the basin-tocanal door. Storage capacity is limited to a total of 13 test tubes. The test tube rack which is constructed of aluminum Ibeams is similar to the other storage racks.

The Storage Basin No. 2 was originally a second cask basin which has since been converted to a storage basin by the addition of storage racks. Dimensionally, it is identical with the cask basin $\left(13^{\prime} \times 27^{\prime} \times 29^{\prime}\right.$ deep). The inspection basin is $5^{\prime}$ wide by $30^{\prime}$ long with floors at depths of $14^{\prime}$ and $29^{\prime}$. A $3^{\prime}$ diameter by $15^{\prime}$ deep pit is located in the floor at the $29^{\prime}$ depth. The disassembly basin is $5^{\prime}$ wide $x 40^{\prime}$ long $\times 14^{\prime}$ deep. Centered in the floor of the basin is a depression in the shape of an inverted pyramid with a $4.5^{\prime} \times 6^{\prime}$ base and an apex that is $5.5^{\prime}$ below the floor. The repackaging basin is $5^{\prime}$ wide $\times 4^{\prime}$ ' long with three floors at depths of $15^{\prime}, 18^{\prime}$, and $29^{\prime}$. The controls for the operation of all facility pumps, valves, and other equipment used for the purification and disposal of basin water are located in the control room.

Several additional operations include the purification of the basin water, the regeneration of ion exchange resins used for purification of basin water, the cleaning of target elements, and waste disposal.

Waste Tank EP37 is a floor drain collection tank which drains to Tank EP38. This 1,000 gallon tank is constructed of Type 304 stainless steel. It has a $5.5^{\prime}$ outside diameter by $6{ }^{\prime}$ high with 3/16" thick walls. 
Section 5

Technical Data summary supporting the INEL spent Fuel EIS

Document No. NMP-PIS-930182, Revision 2

Narch 22, 1924

Waste Tank EP38 is used to collect and neutralize liquid waste from Buildings $244-\mathrm{H}$ and $245-\mathrm{H}$. This waste is then discharged to the seepage basin, to Tank 717 , or to the waste farm. The tank has a $10.5^{\prime}$ diameter by $10.5^{\prime}$ high with $0.25^{\prime \prime}$ thick walls.

Tank capacity is approximately 6,400 gallons. The deionizer consists of a $5^{\prime}$ diameter by $5^{\prime}$ 'high tank containing a mixture of resins which removes both radioactive and nonradioactive ions from the basin water. The Resin Regeneration Facility consists of three major units: (1) a concrete shielded resin regeneration cell; (2) a control room; and (3) an exterior platform with hose racks. The resin regeneration cell contains three cylindrical tankș; EP57, 59 and 63 .

Table 29

\section{RBOF Tank Descriptions}

\begin{tabular}{|c|c|c|c|}
\hline Tank Description & $\begin{array}{c}\text { Capacity } \\
\text { (gallons) }\end{array}$ & $\begin{array}{c}\text { Diameter } \\
\text { (feet) }\end{array}$ & $\begin{array}{c}\text { Height } \\
\text { (feet) }\end{array}$ \\
\hline $\begin{array}{c}\text { Classification Tank } \\
\text { (EP57) }\end{array}$ & 900 & 4 & 9 \\
\hline $\begin{array}{c}\text { Anion Resin } \\
\text { (EP59) }\end{array}$ & 500 & 3 & 9 \\
\hline Resin Storage Tank \\
(EP 63)
\end{tabular}

\section{SAFETY FEATURES}

Accidents which result in the release of radioactivity in the $R B O F$ are of concern as are accidents which result in either the direct exposure of personnel to radiation or the inhalation of airborne activity by personnel.

The RBOF facility utilizes a number of engineered safety features. Where the potential for release of airborne radioactivity or contamination exists, plastic "huts" are erected over the basin from which the exhaust air is passed through a HEPA filter to remove radioactive particulates. The building ventilation system with HEPA filters serves to minimize airborne radioactivity both in and outside the facility. In the event of an activity level within the building sufficient to actuate the nuclear incident monitors (NIMs), all exhaust and supply fans are automatically shutdown as the building is evacuated. 
Racks in the storage basins are designed to hold the spent fuel elements at fixed, criticality safe distances to maintain subcriticality. Many specialized monitors are employed for the detection of radiation and airborne radiation activity. Six NIMs which are installed in pairs at three locations are designed to alert facility personnel to evacuate the building in the event of a criticality incident.

The facility design provides several types of shielding to protect personnel from direct exposure to gamma radiation. The water that covers all fuel in the basins is one such shielding.

The filter-deionizer loop located in the decontamination cell is employed to remove water borne, radioactive contamination from basin and canal water. Provision exists also for the handling of gross levels of basin contamination which might occur as a result of certain uncommon accident scenarios. The RBOF was purposely sited adjacent to a waste tank farm and connected thereto by headers through which the basin water can be pumped to a storage tank. It is expected that an inventory as large as one million curies could be sent to the storage tank, if necessary.

SRS has many years of good experience with the handling and storage of Al-clad fuels and target assemblies in RBOF storage facility. Table 8 gives the capacity of RBOF including a summary of the locations occupied by different spent fuel types. The majority of the space is allotted to SST/Zr clad spent fuels. These spent fuels are safe to store for long periods of time in RBOF as long as the water chemistry is maintained. Although the spent fuels are generally processed within a year of receipt, some Al-clad fuels have been stored in RBOF for more than 10 years without evidence of significant cladding penetration as evidenced by low fission product release into the water (see Table 9). A number of special Al-clad reactor assemblies for transplutonium isotope production have also been stored for more than 10 years without significant deterioration. The aluminum racks in RBOF do not show signs of significant corrosion after almost 30 years of submersion. Corrosion of aluminum in deionized water is slow $\left(0.15 \mathrm{mils} /\right.$ year at $\left.40^{\circ} \mathrm{C}\right)$ so one would not expect to see any deterioration of the thick Al storage racks. 
Section 5

Technical Data summary supporting the INEI Spent Fuel EIS

Document No. NMP-PLS-930182, Revision 2

March 22,1924

DATA:

Facility Size/Construction: $\quad 139^{\prime} \times 148^{\prime}$ ' Reinforced

Concrete/ Steel

Critical Design/Safety Features: High Resistance Class 1

Nuclear Criticality

Decontamination Control

Land Area:

$200^{\prime} \times 200^{\prime}$

Land Area Disturbed by

$\mathrm{N} / \mathrm{A}$

Construction:

Capacity:

Utility Requirements:

Electricity

Steam

Domestic Water

See Table 8

1,430 megawatts

$25,000 \mathrm{~K}$ lbs./yr

$9,276 \mathrm{~K}$ gals/yr

Capital Cost:

$\mathrm{N} / \mathrm{A}$

Annual Operating Cost:

$\$ 9.0 \mathrm{M}$

Life Cycle

$\mathrm{N} / \mathrm{A}$

Schedule:

Time to Begin

$\mathrm{N} / \mathrm{A}$

Time to Complete

$\mathrm{N} / \mathrm{A}$

Annual Construction Personnel:

10

Annual Operations Personnel:

50

Chemical Inventory:

Nitric Acid

Phosphoric Acid

Oxalic Acid

Sodium Hydroxide

Sodium Dichromate

Waste:

Canisters (MTU)

Saltstone (CY/MTU)

The resins are washed in

TRU Waste (CY/MTU)

RBOF, the waste go to WM:

Sanitary (gal/yr.) 
Section 5

Techntcal Data summary supporting the INEL spent Fuel EIS Document No. NMP-PLS-930182, Revision 2

March 22. 1294

\section{AIRBORNE AND LIQUID EMISSIONS BY RELEASE POINTS:}

The air emissions from this facility are not presently monitored.

Liquid emissions are directed to existing waste treatment

facilities.

OREN ISSUES :

RBOF can continue to operate under the current conditions without any facility or equipment upgrades which will require significant capital expenditures and without any additional NEPA

documentation.

A large annual operating budget is required.

TABLE 30

RBOF CAPACITY AND USAGE

Inventory Date - March 1, 1992

\begin{tabular}{|l|c|c|}
\hline Type Cladding & Spaces Allotted & Spaces occupied \\
\hline SST/ Zr Clad & 1,773 & 1,574 \\
\hline Al Clad & 809 & 603 \\
\hline Unallocated & 215 & 0 \\
\hline Nuclear Safety Rows & 0 & 98 \\
\hline TOTALS & $\mathbf{2 , 7 9 7}$ & $\mathbf{2 , 2 7 5}$ \\
\hline
\end{tabular}


Section 5

Technical Data sumary supporting the INEI spent ruel zIs

Document No. NMP-PLS-930182, Revision 2

March 23, 1924

TABLE 31

BBOF AIUMTNUM CIAD SPENT FUET INVEFNORY

Inventory Date - March 1, 1992

Non-Production Fuels

\begin{tabular}{|c|c|c|c|c|c|}
\hline Reactor & $\begin{array}{c}\text { Percent } \\
\text { U }-235 \\
\text { Enrichment }\end{array}$ & $\begin{array}{c}\text { Total } \\
\text { Uranium } \\
\text { (kg) }\end{array}$ & $\begin{array}{c}P u-239 \\
(k g)\end{array}$ & $\begin{array}{l}\text { Year of } \\
\text { Oldest } \\
\text { Receipt }\end{array}$ & $\begin{array}{c}\text { Processing } \\
\text { Option }\end{array}$ \\
\hline EBR-II & 0.2 & $22,105.3$ & 76.2 & 1986 & $221-E$ \\
\hline JMTR-JRR & 88.1 & 16.8 & 0.0 & 1989 & $221-\mathrm{H}$ \\
\hline NEREIDE & 19.8 & 35.4 & 0.0 & 1982 & $221-H$ \\
\hline ORR & 82.2 & 20.6 & 0.0 & 1988 & $221-\mathrm{H}$ \\
\hline ORR-LEU & 15.8 & 95.0 & 0.0 & 1989 & $221-H$ \\
\hline RHF & 82.0 & 25.3 & 0.0 & 1982 & $221-\mathrm{H}$ \\
\hline SEF & 77.5 & 34.0 & 0.0 & 1988 & $221-H$ \\
\hline SFO & 93.2 & 100.8 & 0.0 & 1984 & 221-H \\
\hline TRR & 0.6 & $55,901.3$ & 14.6 & 1990 & $221-F$ \\
\hline TOTAIS & & $78,334.5$ & 90.8 & & \\
\hline
\end{tabular}

Table 32

SRS Reactor Asembly Inyentory

(No. 2 Cask Basin)

\begin{tabular}{|l|c|c|}
\hline $\begin{array}{l}\text { Assembly } \\
\text { Designation }\end{array}$ & $\begin{array}{c}\text { Number } \\
\text { of } \\
\text { Assemblies }\end{array}$ & $\begin{array}{c}\text { Year } \\
\text { Stored at } \\
\text { RBOF }\end{array}$ \\
\hline$M R-18 A$ & 65 & 1979 \\
\hline$M K-42$ & 16 & 1983 \\
\hline$M K-16$ & 1 & 1984 \\
\hline OX -2 & 1 & 1984 \\
\hline$U S-1$ & 1 & 1983 \\
\hline US -2 & 3 & 1983 \\
\hline
\end{tabular}


Technical. Data Summary supporting the INEI spent Fuel EIS

Document No. NMP-PLS-930182, Revision 2

March 22, 1924

\section{SECTION 6}

\section{SUPPORTING COST INFORMATION}


ASSOCIATED "ROUGH ORDER OF MAGNITUDE" ESTIMATED COSTS OF EXISTING SRS FACILITIES

\begin{tabular}{|c|c|c|c|c|c|c|c|}
\hline FACILITY & $\begin{array}{c}\text { TEC (1) } \\
\text { (sMiLLIoNs) }\end{array}$ & $\begin{array}{c}\text { TPC } \\
\text { (SMILLIONS) }\end{array}$ & $\begin{array}{l}\text { OPEAATINO } \\
\text { COST/YR (2) } \\
\text { (SHILLIONS) }\end{array}$ & $\begin{array}{c}\text { MATERIALL } \\
\text { COST/YA } \\
\text { (\$MILLIONS) }\end{array}$ & $\begin{array}{c}\text { WASTE } \\
\text { DISPOSAL } \\
\text { COST/YR } \\
\text { (SMILLIONS) }\end{array}$ & $\begin{array}{l}\text { MAINTENANCE } \\
\text { COST/YR } \\
\text { (SMILLIONS) }\end{array}$ & $\begin{array}{c}\text { ANNUAL } \\
\text { PROCESSING } \\
\text { COST } \\
\text { (\$MILLIONS) }\end{array}$ \\
\hline \multicolumn{8}{|l|}{ F-GANYON } \\
\hline & 0.0 & 0.0 & 47.6 & 3.5 & 40.2 & 7.0 & 48.7 \\
\hline $\begin{array}{l}\text { FB-LWEELESS } \\
\text { VAUL'T) }\end{array}$ & 0.0 & 0.0 & 31.3 & 2.3 & 40.4 & 4.6 & 40.4 \\
\hline \multicolumn{8}{|l|}{ H-CANYYN } \\
\hline & 0.0 & 0.0 & 52.9 & 3.9 & 44.8 & 7.7 & 54.2 \\
\hline \multicolumn{8}{|l|}{ USF (LESS VAULT) } \\
\hline & 0.0 & 0.0 & 10.6 & 0.8 & 11.7 & 1.5 & 12.5 \\
\hline ther & 0.0 & 0.0 & 8.5 & 0.6 & 7.2 & 1.2 & 8.7 \\
\hline \multicolumn{8}{|l|}{ RX Busmes } \\
\hline & 0.0 & 0.0 & 12.3 & 0.9 & 10.4 & 1.8 & 12.6 \\
\hline $\begin{array}{l}\text { MB-LWE: PAODUCT } \\
\text { STORAGE FACUITY }\end{array}$ & & & & & & & - \\
\hline & & 0.0 & 9.0 & 0.8 & 14.9 & 1.4 & 14.0 \\
\hline $\begin{array}{l}\text { USF: PAODUCT } \\
\text { STOAMCE FACLLTV }\end{array}$ & 0.0 & 0.0 & 3.3 & 0.2 & 2.8 & 0.5 & 3.4 \\
\hline 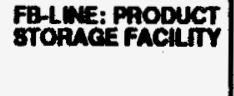 & 0.0 & 0.0 & 16.4 & 1.2 & 1.2 & 2.4 & 9.2 \\
\hline
\end{tabular}


ASSOCIATED "ROUGH ORDER OF MAGNITUDE" ESTIMATED COSTS OF NEW SRS PROCESS FACILITIES

\begin{tabular}{|c|c|c|c|c|c|c|c|c|c|}
\hline $\begin{array}{l}\text { NEW } \\
\text { FACILITY }\end{array}$ & $\begin{array}{c}\text { TEC (1) } \\
\text { (BMHLION8) }\end{array}$ & $\begin{array}{c}\text { TPC } \\
\text { (8MILLION8) }\end{array}$ & $\begin{array}{l}\text { OPEAATIME } \\
\text { COST/YA (2) } \\
\text { (AMILLIONS) }\end{array}$ & $\begin{array}{c}\text { MATEFIAL } \\
\text { COST/YA } \\
\text { (BMILLIONS) }\end{array}$ & $\begin{array}{c}\text { WASTE } \\
\text { DISPOSAL } \\
\text { COST/YR } \\
\text { (\$MILLIONS) }\end{array}$ & $\begin{array}{l}\text { MAINTENAMCE } \\
\text { COST/YR } \\
\text { (\$MILLIONS) }\end{array}$ & $\begin{array}{l}25 \text { YEAR } \\
\text { OPEAATING } \\
\text { LIFE CYCLE } \\
\text { COST } \\
\text { (\$MILLIONS) }\end{array}$ & $\begin{array}{c}\text { DED } \\
\text { LIABILITY } \\
\text { COSTS } \\
\text { (\$MILLIONS) }\end{array}$ & $\begin{array}{l}25 \text { YEAA } \\
\text { TOTAL LIFE } \\
\text { CYCLE COSY } \\
\text { LIABILITY } \\
\text { (SMILLIONS) }\end{array}$ \\
\hline \multicolumn{10}{|l|}{ FUE nEcevman } \\
\hline & 120.0 & 174.0 & 12.3 & 0.9 & 10.4 & 1.8 & 809.2 & 135.7 & 945.0 \\
\hline
\end{tabular}

FUEL REPACKACMO

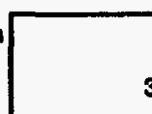

30.0

43.5

3.3

0.2

2.8

0.5

212.9

33.9

246.8

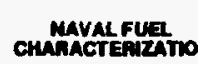

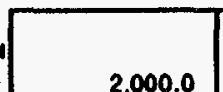

$2,000.0$

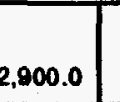

30.3

2.2

4.8
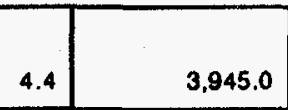

\section{$2,262.0$}

$6,207.0$

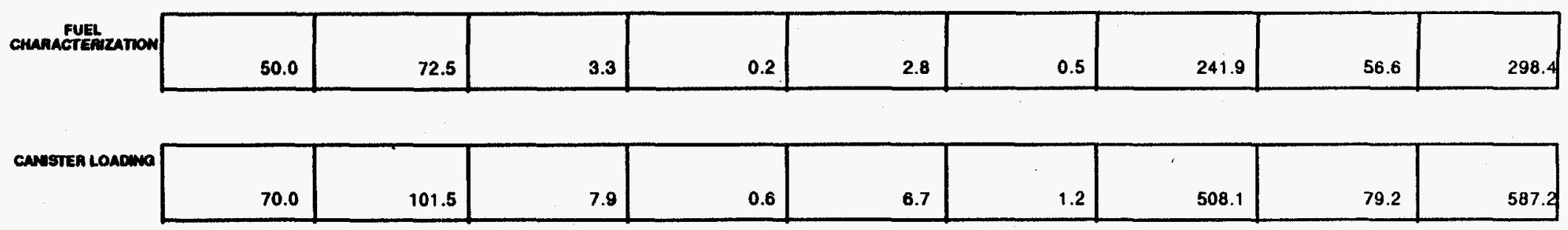


ASSOCIATED “ROUGH ORDER OF MAGNITUDE" ESTIMATED COSTS OF NEW SRS STORAGE FACILITIES

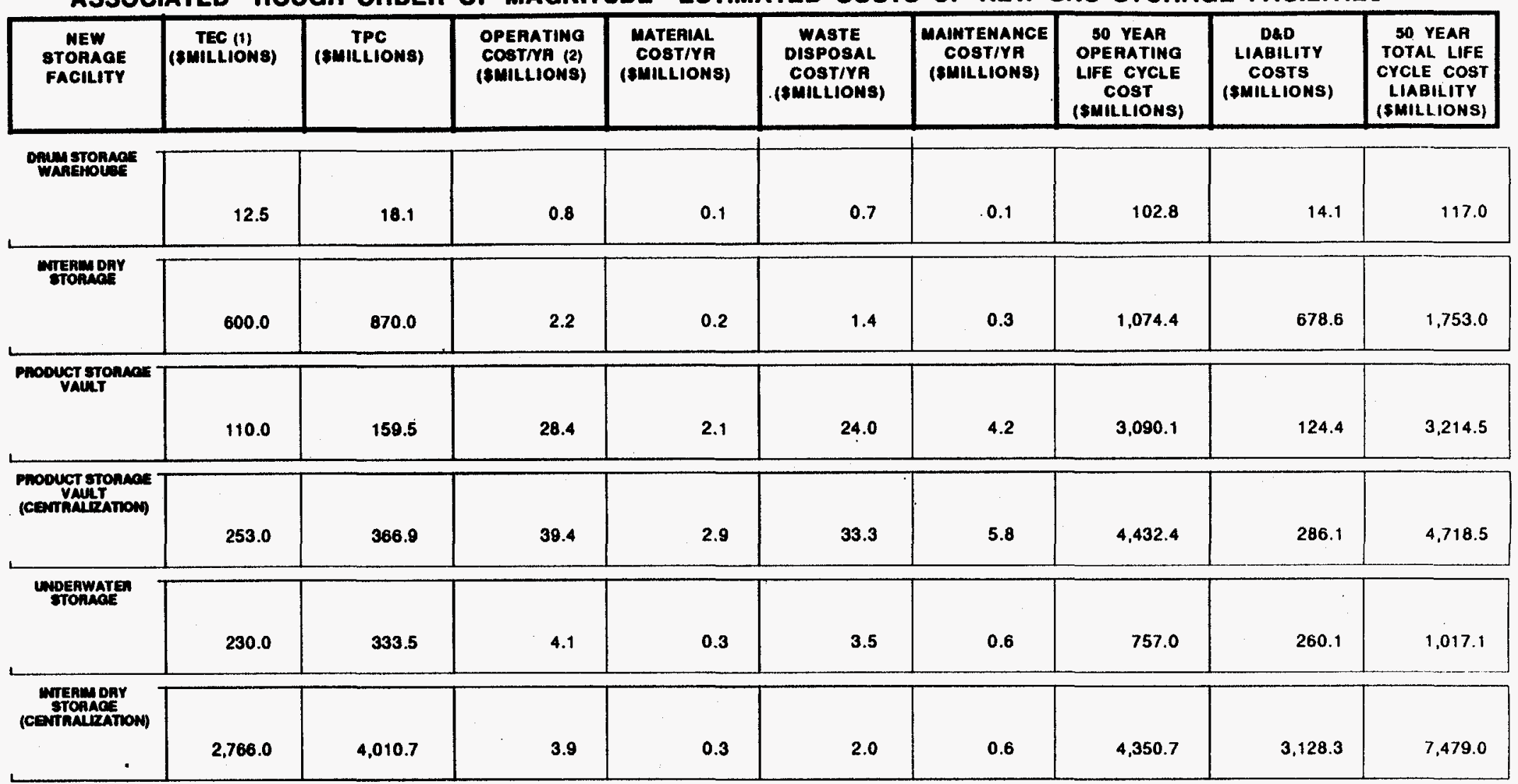


Section 7

Technical Data Summary Supporting the INEL spent ruel EIS

Document No. NMP-PIS-930182, Revision 2

March $22, \quad 1294$

\section{SECTION 7}

\section{Evaluation of the Impact of Spent Nuclear Fuel}

Alternatives on SRS Air and Water Emissions 
Section 7

Technical Data summary supporting the INEL spent ruel EIS

Document No. NMP-PIS-930182, Revision 2

Warch 22, 1994

option 1: No Action

Case Description

Case 1:

SRS will provide for the extended wet storage in existing facilities. Al clad

fuel inventory will be

transferred to RBOF, non Al

clad fuels stored in a

reactor basin.
Air Emissions

< base case as fuel is stored underwater.
Hater missions

Option 2: Decentralization

\section{Case Description}

Case 2a:

Process current SRS fuel inventory to consolidate and stabilize SNM for vault storage. No additional receipts will be accepted.

Case 2b:

Store the current SRS fuel inventory in new wet storage facilities plus provide additional capabilities to examine, characterize, and package fuel elements. No additional receipts will be accepted.

Case 2c:

Store the current SRS fuel inventory in new dry storage facilities plus additional capabilities to examine, characterize, and package fuel elements. No additional receipts will be accepted.

\section{Air Emissions}

= base case as the same total spent fuels are processed. Annual emission rate will be = base case.

< base case fewer spent fuels are stored underwater.

$>$ bàse case, fewer spent fuels are stored. Effects of long term dry storage on Al

clad fuels are unknown.

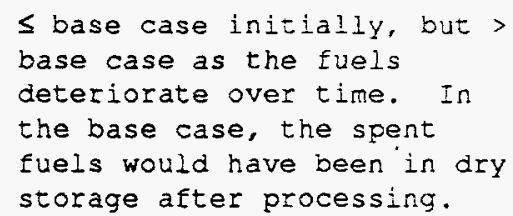

= base case, total emissions will be the same as the same spent fuels are processed. Annual emission rate will be = base case.

< base case, fewer spent fuels are stored underwater for the entire storage period subject to corrosion.

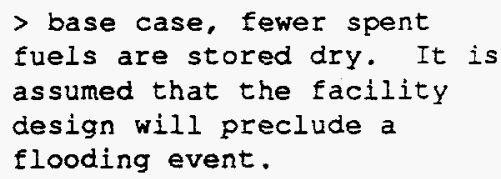


Section 7

Technical Data summary Supporting the INEI spent Fuel EIS

Document No. NMP-PLS-930182, Revision

March 22. 1994

eption 3: Planning Basis

\section{Case Description}

Case 3a:

SRS will process current fuel inventories. Receipts will be stored in new dry storage facilities.

Case 3b:

SRS will provide for the interim wet storage in new facilities for current SRS inventories and $\mathrm{Al}$ clad receipts.

Case 3c:

SRS will provide for the extended dry storage in new facilities for current SRS inventories and Al clad receipts.

\section{Air Fmissiens}

Base Casel

$\leq$ base case, as spent fuels are stored underwater with no processing.

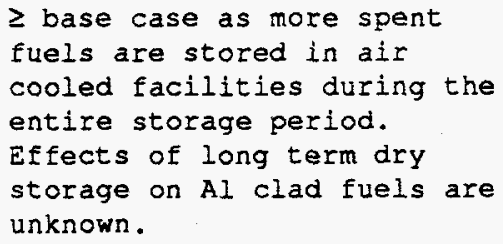

\section{Water Emissions}

\begin{abstract}
$\geq$ base case as more spent fuels are stored underwater subject to corrosion during the entire storage period.
\end{abstract}

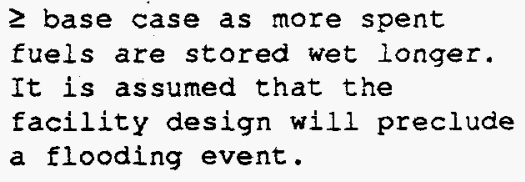
fuels are stored wet longer. It is assumed that the facility design will preclude a flooding event.

1 See air emissions data in Attachment 1.

2 See water emissions data in Attachment 2. 
Section 7

Technical Data summary supporting the INEL spent Fuel EIS

Document No, NMP-PLS-930182, Revision 2

March 22,2994

Option 4: Regionalization

\section{Case Description}

Case 4a:

SRS will process the SRS AI clad fuel inventories to stabilize SNM for vault storage. The Al clad receipts will be dry stored in new facilities. The special clad fuel inventory will be shipped offsite for disposition.

\section{Case 4b:}

SRS will provide for the interim wet storage in new facilities for all DOE owned Al clad fuels. The special clad fuel inventory will be shipped offsite for disposition.

\section{Case 4c:}

SRS will provide for the interim dry storage in new facilities for all DOE owned Al clad fuels. The special clad fuel inventory will be shipped offsite for disposition.
Air Emissions

$\geq$ base case for total emissions, more spent fuels are handled, but slightiy less spent fuels are placed into storage.

$\leq$ base case, as more spent fuels are handled, but there are no processing emissions.

$\checkmark$ base case as fewer spent fuels stored with no processing emissions. More spent fuels are handled. Effects of long term dry storage on Al clad fuels are unknown.

\section{Hater Emissions}

$\geq$ base case, more spent fuels are handled.

$\geq$ base case as less spent fuels are stored in a wet basin for entire storage period subject to corrosion with no processing emissions, but more spent fuels are handled.

$\leq$ base case as fewer spent fuel are stored dry with no processing emissions. More spent fuels are handled. It is assumed that the facility design will preclude a flooding event. 
Section 7

Technical Data summary supporting the INEL spent Fuel EIS

Document No. MMP-PIS-930182, Revision 2

March $22, \quad 1994$

option 5i Centralization

Case Description Air Emissions

Case 5a:

SRS will process the current SRS spent fuel inventory.

The balance of the DOE

inventory will be dry stored.

\section{Case 5b:}

SRS will provide for the interim wet storage in new facilities for all DOE owned fuels.

Case 5c:

SRS will provide for the extended dry storage in new facilities for all DOE owned fuels plus additional capabilities to examine. characterize, and package fuel elements.

\section{Case 5d:}

SRS will ship the entire SRS fuel inventory to another central location for disposition.

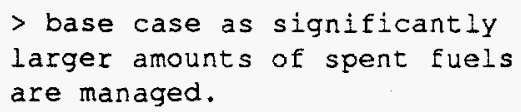

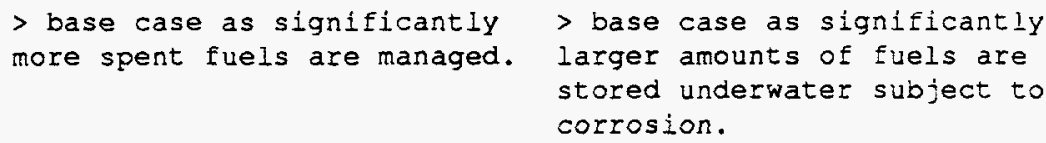

$>$ base case as significantly more spent fuels are managed. Effects of long term dry storage on AI clad fuels are unknown.

< base case as spent fuels are no longer stored or processed at SRS.
$>$ base case as significantly more spent fuels are stored.
< base case as spent fuels are no longer stored or processed at SRS. 
Attachment I

The Technical Data summary supporting the INzL spent Fuel eIs

Document

NMP-PLS-930182, Revision 2

March $23 \quad 1994$

\section{Attachment 1<smiles>[CH+]</smiles>

Section 7

$F$ and $H$ Areas

Air Emissions

Data 
Attachmont 1

The Technlcal Data Summary supporting the INEl spent ruel eIs

Document Mo. MA-PLS-930182, Revision 2

March 23, 1994

TABLE 1

AIR TOXICS EMITTED BY CANYON SOURCES

E AND H Areas

Point Sources only

\begin{tabular}{|c|c|c|}
\hline Source ID & Pollutant & $\begin{array}{c}\text { Emission Rate } \\
(g / s)\end{array}$ \\
\hline Exhaust Stack $291-\bar{E}$ & Nitric Acid & $3.570 E+00$ \\
\hline Exhaust Stack 291-H & 1,1,1 Trichloroethane & $6.638 \mathrm{E}-05$ \\
\hline & Ethyl Benzene & $2.309 E-05$ \\
\hline & Ethylene Glycol & $5.835 \mathrm{E}-04$ \\
\hline & Hexane & $3,310 \mathrm{E}-04$ \\
\hline & Manganese & $4.354 E-04$ \\
\hline & Metnyl Alcohol & $4.875 \mathrm{E}-04$ \\
\hline & Methyl Ethyl Ketone (2-Butone) & $9.359 E-04$ \\
\hline & Methyl Isobutyl Ketone & $3.673 \mathrm{E}-04$ \\
\hline & Methylene Chloride & $1.832 \mathrm{E}-04$ \\
\hline & Naphthalene & $7.211 E-07$ \\
\hline & Phenol & $1.731 \mathrm{E}-06$ \\
\hline & Phosphorus & $4.473 \mathrm{E}-08$ \\
\hline & Toluene & $6.301 \mathrm{E}-04$ \\
\hline & Trichloroethylene & $1.587 \mathrm{E}-05$ \\
\hline & Vinyl Acetate & $1.442 \mathrm{E}-06$ \\
\hline & xylene & $2.471 E-03$ \\
\hline
\end{tabular}

TABLE 2

CRITERION POLLUTANTS EMITTED BY CANYON SOURCES

F AND $\mathrm{E}$ Areas

Point Sources Only

\begin{tabular}{|l|c|c|}
\hline Source ID & Pollutant & $\begin{array}{c}\text { Emission Rate } \\
(\mathrm{g} / \mathrm{s})\end{array}$ \\
\hline Exhaust Stack 291-F & Hydrogen Fluoride & $7.021 \mathrm{E}-01$ \\
\hline & Oxides of Nitrogen & $5.558 \mathrm{E}+02$ \\
\hline Exhaust stack 291-H & Carbon Monoxide & $2.633 \mathrm{E}-03$ \\
\hline & Oxides of Nitrogen & $2.909 \mathrm{E}+00$ \\
\hline & Oxides of Sulfur & $8.429 \mathrm{E}-03$ \\
\hline & Particulate Matter (10 microns) & $1.372 \mathrm{E}-02$ \\
\hline & Total Particulate Matter & $1.372 \mathrm{E}-02$ \\
\hline
\end{tabular}




\author{
Attachment 2 \\ to \\ Section 7 \\ $F$ and $H$ Areas \\ Water Emissions \\ Data
}


The Technical Data Summary Supporting the INEI spent Fuel zIs

Document No. NMP-PLS-930182, Revision 2

March $23, \quad 1294$

Please refer to Revision 1. This data was not issued in Revision

2 since there were no changes from Revision 1. 